In cooperation with the U.S. Fish and Wildlife Service, Science Applications Program, Great Plains Landscape Conservation Cooperative

\title{
Using Scenarios to Evaluate Vulnerability of Grassland Communities to Climate Change in the Southern Great Plains of the United States
}

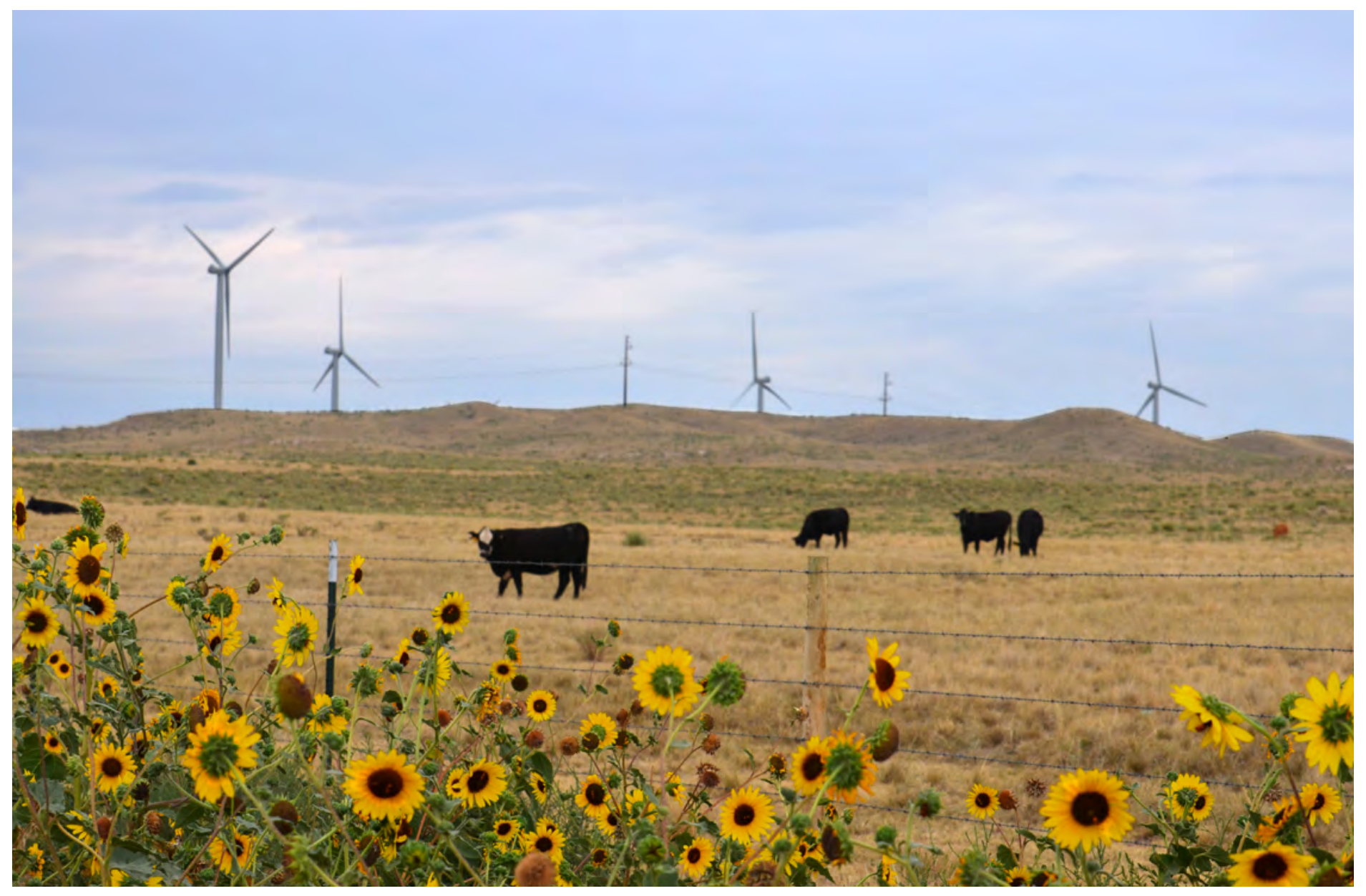

Open-File Report 2019-1046 
Cover. Wind turbines and domestic cattle grazing in grassland illustrate energy development and the shift in dominance from native herbivores to domestic livestock. Photograph by Natasha Carr, U.S. Geological Survey, August 23, 2012. 


\section{Using Scenarios to Evaluate Vulnerability of Grassland Communities to Climate Change in the Southern Great Plains of the United States}

By Daniel J. Manier, Natasha B. Carr, Gordon C. Reese, and Lucy Burris

In cooperation with the U.S. Fish and Wildlife Service, Science Applications

Program, Great Plains Landscape Conservation Cooperative

Open-File Report 2019-1046 


\title{
U.S. Department of the Interior DAVID BERNHARDT, Secretary
}

\author{
U.S. Geological Survey \\ James F. Reilly II, Director
}

U.S. Geological Survey, Reston, Virginia: 2019

For more information on the USGS - the Federal source for science about the Earth, its natural and living resources, natural hazards, and the environment-visit https://www.usgs.gov or call 1-888-ASK-USGS.

For an overview of USGS information products, including maps, imagery, and publications, visit https://store.usgs.gov.

Any use of trade, firm, or product names is for descriptive purposes only and does not imply endorsement by the U.S. Government.

Although this information product, for the most part, is in the public domain, it also may contain copyrighted materials as noted in the text. Permission to reproduce copyrighted items must be secured from the copyright owner.

Suggested citation:

Manier, D.J., Carr, N.B., Reese, G.C., and Burris, L., 2019, Using scenarios to evaluate vulnerability of grassland communities to climate change in the Southern Great Plains of the United States: U.S. Geological Survey, Open-File Report 2019-1046, 48 p., https://doi.org/10.3313/ofr20191046.

ISSN 0196-1497 (print) ISSN 2331-1258 (online) ISBN 978-1-4113-4297-2 


\section{Acknowledgments}

We acknowledge staff and partners of the U.S. Fish and Wildlife Service, Science Applications Program, Great Plains Landscape Conservation Cooperative (GPLCC) for guidance and assistance in the scope and implementation of this research, especially: Nicole Athearn (formerly GPLCC), James Broska (U.S. Fish and Wildlife Service), Jonathan Hayes (formerly GPLCC), and Amie Truer-Kuehn (Texas Parks and Wildlife Department). We especially thank additional participants in the Fort Collins Project Kickoff Meeting: Reesa Conrey and George Schisler (Colorado Parks and Wildlife); Alex Daniels and Kyle Taylor (Playa Lakes Joint Venture); Bruce Hoagland (Oklahoma Department of Wildlife Conservation); Brian Trusty, John Takekawa, and Curtis Burhkalter (National Audubon Society); and Mike Langston, Kim Winton, and Carlos Gaitan (South-Central Climate Science Center). Special thanks are extended to Amie Truer-Kuehn, Texas Parks and Wildlife, and Bruce Hoagland, Oklahoma Department of Wildlife Conservation, for supplying field data that supported evaluation and parameterization of our models. We also appreciated the assistance of U.S. Geological Survey (USGS) staff who provided guidance and assistance during different stages of this project: Aaron Freeman (formerly Fort Collins Science Center), Sarah Carter (Fort Collins Science Center), Jeff Morisette (formerly North Central Climate Science Center), Marian Talbert (formerly North Central Climate Science Center), Colin Talbert (Fort Collins Science Center, and formerly North Central Climate Science Center) and Terry Sohl (Earth Resources Observation and Science Center). Reviews of the manuscript were provided by Jeff Morisette and Brian Miller. Finally, we acknowledge the World Climate Research Programme's Working Group on Coupled Modelling, which is responsible for the Coupled Model Intercomparison Project (CMIP), and we thank the climate modeling groups (listed in table 2) for producing and making their model output available for use. The U.S. Department of Energy's Program for Climate Model Diagnosis and Intercomparison provides coordinating support and led development of software infrastructure in partnership with the Global Organization for Earth System Science Portals for CMIP. 


\section{Contents}

Acknowledgments .............................................................................................................ii

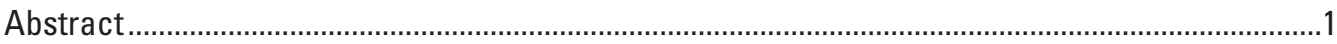

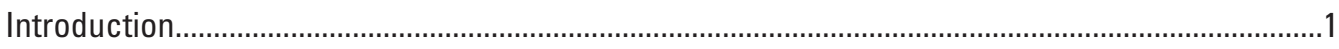

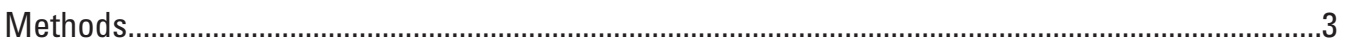

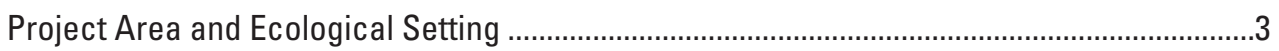

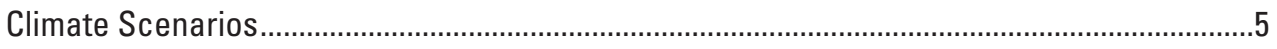

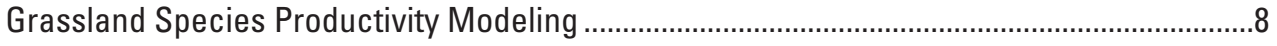

Indicator Species

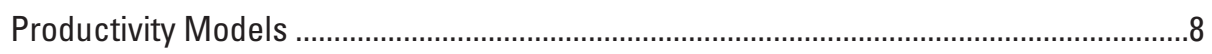

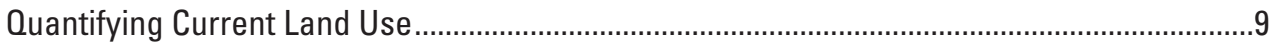

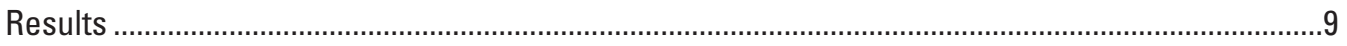

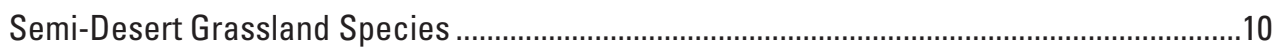

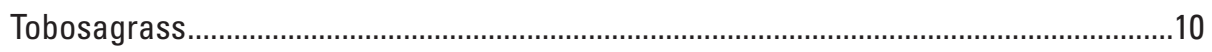

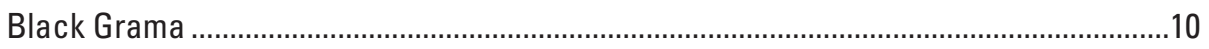

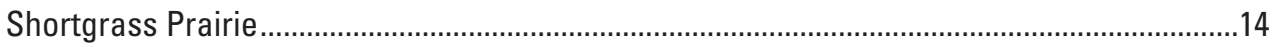

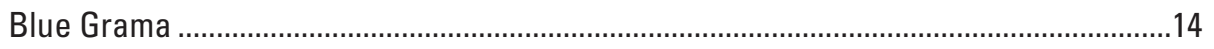

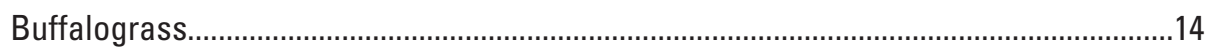

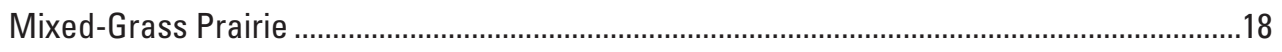

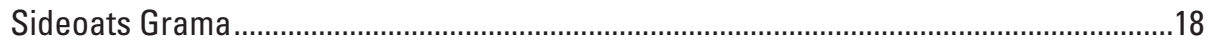

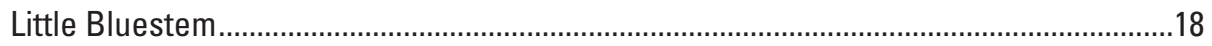

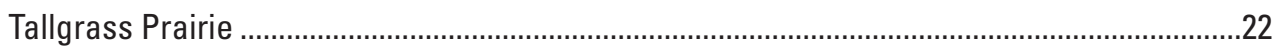

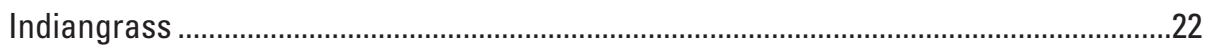

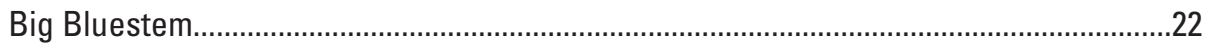

Community-Level Vulnerability to Climate Scenarios.............................................................26

Relative and Synergistic Effects of Land Use and Climate Change .......................................26

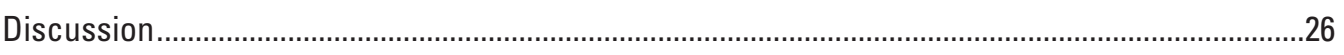

Uncertainty in Future Distribution, Structure, and Composition of

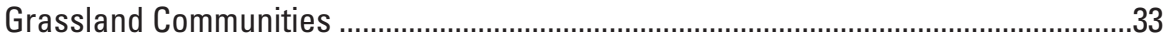

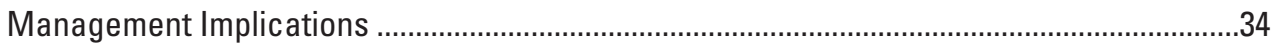

Potential Implications for Landscape Conservation Design ..................................................34

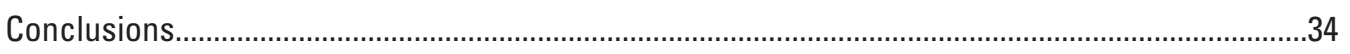

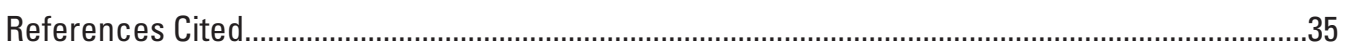

Appendix 1. Classified Relative Production Estimates............................................................39

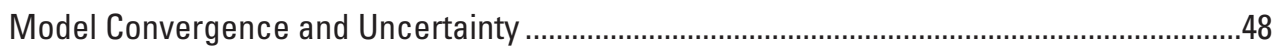




\section{Figures}

1. Maps showing $A$, Grassland communities of the Southern Great Plains of the United States and $B$, spatial patterns of land use as represented by the terrestrial development index (TDI), as applied to grassland communities...

2. Maps showing mean temperature for the contemporary climate and the changes projected for four climate scenarios compared to contemporary temperatures..............6

3. Maps showing mean precipitation for the contemporary climate and the changes projected for four climate scenarios compared to contemporary precipitation

4. Maps showing difference in the predicted relative productivity of Pleuraphis mutica (tobosagrass) an indicator species for semi-desert grasslands, as modeled using four climate scenarios

5. Maps showing difference in the predicted relative productivity of Bouteloua eriopoda (black grama), an indicator species for semi-desert grasslands, as modeled using four climate scenarios

6. Maps showing difference in the predicted relative productivity of Bouteloua gracilis (blue grama), an indicator species for shortgrass prairie, as modeled using four climate scenarios

7. Maps showing difference in the predicted relative productivity of Bouteloua dactyloides (buffalograss), an indicator species for shortgrass prairie, as modeled using four climate scenarios...

8. Maps showing difference in the predicted relative productivity of Bouteloua curtipendula (sideoats grama), an indicator species for mixed-grass prairie, as modeled using four climate scenarios

9. Maps showing difference in the predicted relative productivity of Schizachyrium scoparium, little bluestem, an indicator species for mixed-grass prairie, as modeled using four climate scenarios

10. Maps showing difference in the predicted relative productivity of Sorghastrum nutans (Indiangrass), an indicator species for tallgrass prairie, as modeled using four climate scenarios

11. Maps showing difference in the predicted relative productivity of Andropogon gerardii (big bluestem), an indicator species for tallgrass prairie, as modeled using four climate scenarios

12. Maps showing predicted changes in productivity for Pleuraphis mutica (tobosagrass) and Bouteloua eriopoda (black grama) within the current distribution of semi-desert grasslands.

13. Maps showing predicted changes in productivity for Bouteloua gracilis (blue grama) and Bouteloua dactyloides (buffalograss) within the current distribution of shortgrass prairie

14. Maps showing predicted changes in productivity for Bouteloua curtipendula (sideoats grama) and Schizachyrium scoparium (little bluestem) within the current distribution of mixed-grass prairie.

15. Maps showing predicted changes in productivity for Sorghastrum nutans (Indiangrass) and Andropogon gerardii (big bluestem) within the current distribution of tallgrass prairie.

16. Histograms showing predicted changes in productivity of two indicator species for each grassland community within the current distribution of the community for each climate scenario

17. Bar chart showing cumulative effects of development in grassland communities of the

Southern Great Plains and the Landscape Conservation Design pilot area ..... 
A1.1. Maps showing current and predicted relative productivity of Pleuraphis mutica (tobosagrass) using four climate scenarios.

A1.2. Maps showing current and predicted relative productivity of Bouteloua eriopoda (black grama) using four climate scenarios..

A1.3. Maps showing contemporary and predicted relative productivity of Bouteloua gracilis (blue grama) using four climate scenarios

A1.4. Maps showing contemporary and predicted relative productivity of Bouteloua dactyloides (buffalograss) using four climate scenarios

A1.5. Maps showing contemporary and predicted relative productivity of Bouteloua curtipendula (sideoats grama) using four climate scenarios

A1.6. Maps showing contemporary and predicted relative productivity of Schizachyrium scoparium (little bluestem) using four climate scenarios.

A1.7. Maps showing contemporary and predicted relative productivity of Sorghastrum nutans (Indiangrass) using four climate scenarios

A1.8. Maps showing contemporary and predicted relative productivity of Andropogon gerardii (big bluestem) using four climate scenarios.

A1.9. Maps showing agreement and disparity among relative production models using the four climate scenarios

\section{Tables}

1. Area of grassland communities in the Southern Great Plains and within the Great Plains Landscape Conservation Design pilot area, United States

2. Mean temperature and precipitation, and horizontal resolution of the sources, for the contemporary climate and the four climate scenarios evaluated for the Southern Great Plains of the United States

3. Predictor variables and associated parameters for grassland indicator species used to model relative productivity for the Southern Great Plains of the United States ...........8 


\section{Conversion Factors}

U.S. customary units to International System of Units

\begin{tabular}{lcl}
\hline & Multiply & \multicolumn{1}{c}{ Bo obtain } \\
\hline inch (in.) & Length & \\
inch (in.) & 2.54 & centimeter $(\mathrm{cm})$ \\
& 25.4 & millimeter $(\mathrm{mm})$ \\
\hline square foot $\left(\mathrm{ft}^{2}\right)$ & Area & \\
square mile $\left(\mathrm{mi}^{2}\right)$ & 0.09290 & square meter $\left(\mathrm{m}^{2}\right)$ \\
\hline
\end{tabular}

International System of Units to U.S. customary units

\begin{tabular}{|c|c|c|}
\hline Multiply & By & To obtain \\
\hline \multicolumn{3}{|c|}{ Length } \\
\hline centimeter $(\mathrm{cm})$ & 0.3937 & inch (in.) \\
\hline kilometer (km) & 0.6214 & mile (mi) \\
\hline meter $(\mathrm{m})$ & 1.094 & yard (yd) \\
\hline \multicolumn{3}{|c|}{ Area } \\
\hline square meter $\left(\mathrm{m}^{2}\right)$ & 0.0002471 & acre \\
\hline square kilometer $\left(\mathrm{km}^{2}\right)$ & 0.3861 & square mile $\left(\mathrm{mi}^{2}\right)$ \\
\hline
\end{tabular}

Temperature in degrees Celsius $\left({ }^{\circ} \mathrm{C}\right)$ may be converted to degrees Fahrenheit $\left({ }^{\circ} \mathrm{F}\right)$ as follows:

$$
{ }^{\circ} \mathrm{F}=\left(1.8 \times{ }^{\circ} \mathrm{C}\right)+32 \text {. }
$$

Temperature in degrees Fahrenheit $\left({ }^{\circ} \mathrm{F}\right)$ may be converted to degrees Celsius $\left({ }^{\circ} \mathrm{C}\right)$ as follows:

$$
{ }^{\circ} \mathrm{C}=\left({ }^{\circ} \mathrm{F}-32\right) / 1.8 .
$$

\section{Abbreviations}

BLM Bureau of Land Management

CMIP Coupled Model Intercomparison Project

GCM General Circulation models (also known as AOGCM)

GPLCC Great Plains Landscape Conservation Cooperative

IPCC Intergovernmental Panel on Climate Change

LCD Landscape conservation design

NRCS Natural Resources Conservation Service

RCP Representative Concentration Pathways

REA Rapid Ecoregional Assessment

SGP Southern Great Plains

SSURGO Surface Soil Geographic Database

USGS U.S. Geological Survey 



\title{
Using Scenarios to Evaluate Vulnerability of Grassland Communities to Climate Change in the Southern Great Plains of the United States
}

\author{
By Daniel J. Manier, Natasha B. Carr, Gordon C. Reese, and Lucy Burris
}

\section{Abstract}

Scenario planning is a useful tool for identifying key vulnerabilities of ecological systems to changing climates, informed by the potential outcomes for a set of divergent, plausible, and relevant climate scenarios. We evaluated potential vulnerabilities of grassland communities to changing climate in the Southern Great Plains (SGP) and the Landscape Conservation Design pilot area (LCD) for the U.S. Fish and Wildlife Service, Science Applications Program, Great Plains Landscape Conservation Cooperative. Four climate scenarios (warm-dry, warm-wet, hot-dry, and hot-wet) from atmospheric-ocean general circulation models were selected to represent a suite of plausible future climatic conditions. For each scenario, and for contemporary climatic conditions, we predicted the spatial patterns of relative productivity for indicator grass species using statistical models of relative above-ground net primary productivity (hereafter, productivity) based on temperature, precipitation, and soil texture (percent sand, silt, or clay).

Two indicator grass species were selected to represent each of four focal grassland communities: semi-desert grasslands, shortgrass prairie, mixed-grass prairie, and tallgrass prairie. Changes in spatial patterning of bioclimatic conditions conducive for each indicator species as predicted for each climate scenario relative to current land use were used to evaluate potential vulnerability and conservation opportunities for grassland communities. Specifically, the following questions were addressed for each focal grassland community: (1) Where is the productivity of each species predicted to increase, decrease, or remain stable relative to estimated contemporary productivity for the SGP and LCD pilot area, (2) where is the productivity of the two indicator species for each community predicted to increase, decrease, or remain stable, (3) which grassland communities are most vulnerable to changes in composition and vertical structure, (4) how do current land-use patterns contribute to potential vulnerabilities of grassland communities for the climate scenarios evaluated, and (5) how can managers use the vulnerabilities identified to evaluate conservation opportunities in the SGP and LCD?

Current land-use patterns, in combination with the potential effects of a changing climate, pose greater risks to mixed-grass and tallgrass prairies of the SGP compared to semi-desert grasslands and shortgrass prairie. For most climate scenarios evaluated, bioclimatic conditions conducive to the taller species were predicted to contract within some or all the current distribution of mixed-grass and tallgrass prairies within the SGP. An increase in precipitation, however, could potentially ameliorate the negative effects of increasing temperatures as evidenced by higher productivity for the hot-wet scenario compared to the other scenarios for the most vulnerable species. Compounding their greater vulnerability to increasing temperatures coupled with decreasing precipitation, the mixed-grass and tallgrass prairies have been greatly fragmented and converted, primarily by agriculture. In contrast, the climate scenarios evaluated are generally conducive to stable or increasing productivity of indicator species for semi-desert grasslands and shortgrass prairie. In addition, conversion and fragmentation of semi-desert grasslands and shortgrass prairie were relatively low. These results suggest that the synergistic effects of land use and changing climatic conditions could have the greatest effects on the composition and structure of mixed-grass and tallgrass prairies in the SGP. ScienceBase data release files that support this report are available at https://doi.org/10.5066/P9DGJHEP (Manier and others, 2019).

\section{Introduction}

Grasslands of the Great Plains of the United States are characterized by cold, dry winters and hot summers with episodic precipitation, which favors grasses over trees and shrubs (Sims, 1988; Hayden, 1998; Lauenroth and others, 2014). Historically, the species composition, vertical structure, and community dynamics of Great Plains grasslands were driven by the interactive effects of climate, disturbance (such as herbivory and fire), topography, and soils (Epstein and others, 1998; Hayden, 1998; Martinson and others, 2011; Lauenroth and others, 2014). The climate and soils that support Southern Great Plains (SGP) grasslands are also suitable for dryland 
agriculture, irrigated croplands, and rangelands for domestic livestock. Consequently, an estimated 43 percent of the SGP grasslands has been converted and fragmented by development, primarily conversion to croplands and in some areas, energy development (Reese and others, 2017). In addition, altered grazing regimes resulting from a shift in dominance from native herbivores to domestic livestock, fire exclusion, and the spread of invasive species can affect community structure (Conner and others, 2001). Conversion and fragmentation of grasslands can reduce the capacity of species to adapt to changing climatic conditions, and in turn, changing climates can compound the effects of land use. Assessing the vulnerability of grasslands of the SGP to changing climates and development are priority management issues for a variety of Federal agencies and other stakeholders (Reese and others, 2017).

Scenario planning is a valuable tool for applying climate science to the management of natural resources because of the fundamental uncertainties associated with climate change and the consequences for species and communities (Gross and others, 2016; Miller and others, 2017; Symstad and others, 2017a, b). Sources of uncertainty include the magnitude, direction, and spatiotemporal patterning of temperature and precipitation changes, the frequency and magnitude of episodic events such as drought, and the response of species to changing and possibly novel conditions, such as the interactive effects of climate, soils, and the influence from other species (Pearson and Dawson, 2003; Heikkinen, and others, 2006, Wiens and others, 2009). Climate scenarios, in conjunction with quantitative models, can be useful for identifying potential vulnerabilities to climate change and developing feasible strategies for reducing risks to priority ecological communities (Peterson and others, 2003; Symstad and others, 2017a, b). Managers can gain insight into potential alternative outcomes from a set of scenarios to assess relative risk among ecological communities, identify regions with the potential vulnerabilities, and develop management strategies to promote the capacity of ecological communities to adapt to potentially complex and uncertain natural and anthropogenic changes (Peterson and others, 2003; Fisichelli and others, 2016; Gross and others, 2016).

We evaluated three components of vulnerability: potential exposure, sensitivity to projected changes, and the capacity for adaptation (Gonzalez and others, 2010). Potential exposure was represented using the projected deviation of each climate scenario from current conditions. Sensitivity and adaptation were addressed by modeling the predicted effects of climate scenarios on the net, above-ground, primary productivity (hereafter, productivity) of eight indicator species. We evaluated sensitivity within the current spatial extent of the focal grassland community, and we evaluated capacity for adaptation using expansion of bioclimatic conditions outside of the focal grassland community but within the SGP. Contraction of bioclimatic conditions conducive for a grass species within the current range of the focal community was used to indicate high sensitivity and vulnerability to the climate scenarios evaluated, whereas expansion or shifts of bioclimatic conditions conducive for a grass species outside the current range of the focal community was used to indicate potential for adaptation and low vulnerability. Fragmentation of existing grassland communities by development was also used to evaluate adaptive capacity. A parallel effort (Sohl and others, 2017), focused on projected land-use changes in the SGP and LCD regions using the same set of four climate scenarios evaluated here.

Evaluating the potential effects of climate change was a priority for the Great Plains Landscape Conservation Cooperative (GPLCC), a collaborative public and private partnership that provides science and tools for resource managers in their efforts to conserve the species and communities of the Southern Great Plains (Great Plains Landscape Conservation Cooperative, 2011). Landscape Conservation Design (LCD), was a partner-driven approach used by the GPLCC to promote management of sustainable, working landscapes that can adapt to regional and global change, including land-use and climate change (Bartuszevige and others, 2016). In a complementary effort, the Bureau of Land Management (BLM) recently completed a Rapid Ecoregional Assessment (REA) of ecological communities in the Southern Great Plains, which synthesized broad-scale information to evaluate the landscape condition of ecological communities in response to change agents including climate change (Reese and others, 2017).

The priority grassland communities for the Southern Great Plains REA were shortgrass, mixed-grass, and sand prairies (Reese and others, 2017). Although the historical distribution of these grassland types was widespread and contiguous across the region, the cumulative effects of land use, as indicated by the terrestrial development index (TDI), has reduced the extent and continuity of these grasslands (fig. 1) (Reese and others, 2017). To evaluate vulnerability and conservation opportunities for the priority grassland communities of the SGP and the Landscape Conservation Design pilot region for the GPLCC (fig. 1) (Broska, 2013), we used the relative productivity of indicator species as predicted for each climate scenario in relationship to spatial patterns of land use. Specifically, the following questions were addressed for shortgrass, mixed-grass, tallgrass, and semi-arid grassland communities:

1. Where is the productivity of each species predicted to increase, decrease, or remain stable relative to estimated contemporary productivity for the SGP and LCD pilot area?

2. Within the current distribution of each grassland community, where is the productivity of indicator species predicted to increase, decrease, or remain stable?

3. Which grassland communities are most vulnerable to changes in composition and vertical structure?

4. How do current patterns of land use contribute to potential vulnerabilities of grassland communities for the climate scenarios evaluated?

5. How can managers use the vulnerabilities identified to evaluate conservation opportunities in the SGP and LCD? 
Table 1. Area of grassland communities in the Southern Great Plains (SGP) and within the Great Plains Landscape Conservation Design pilot area, United States.

$\left[\mathrm{km}^{2}\right.$, square kilometers; $\mathrm{mi}^{2}$, square miles; na, not available because it does not occur in the pilot area]

\begin{tabular}{|c|c|c|c|c|}
\hline Grassland community & \multicolumn{2}{|c|}{ Southern Great Plains (SGP) } & \multicolumn{2}{|c|}{$\begin{array}{l}\text { Landscape Conservation Design } \\
\text { pilot area }\end{array}$} \\
\hline Shortgrass prairie & $259,964(100,372)$ & 27 & $96,900(37,413)$ & 62 \\
\hline Mixed-grass and midgrass prairies & $198,505(76,643)$ & 21 & $4,852(1,873)$ & 3 \\
\hline Sand prairie ${ }^{1}$ & $169,195(65,326)$ & 18 & $36,829(14,220)$ & 24 \\
\hline Cool-season bunchgrass and northwest mixed-grass praires ${ }^{2}$ & $29,515(65,326)$ & 3 & na & na \\
\hline Foothill grasslands ${ }^{2}$ & $7,117(2,748)$ & 1 & $24(9)$ & 0 \\
\hline
\end{tabular}

${ }^{1}$ Sand prairie was not evaluated because productivity models for indicator species were not available for this community.

${ }^{2}$ Other grasslands that were not evaluated because of limited occurrence in the Southern Great Plains.

\section{Methods}

\section{Project Area and Ecological Setting}

The project area, the Southern Great Plains of the United States, was defined using the extent of the Southern Great Plains REA, which included the Great Plains LCC (Reese and others, 2017). The SGP project area encompasses 961,105 square kilometers $\left(\mathrm{km}^{2}\right)$ (371,085 square miles $\left[\mathrm{mi}^{2}\right]$ ) and includes the full extent of four Level-III ecoregions - High Plains, Central Great Plains, Southwestern Tablelands, and Nebraska Sand Hills (Omernik, 1987). Nested within the project area, the Landscape Conservation Design pilot area (LCD) is 147,308-km² (56,876-mi²; fig. $1 A)$ located within the High Plains ecoregion.

The climate of the SGP is characterized by seasonal patterns and spatial gradients that have a strong effect on the composition and structure of vegetation (Sims, 1988; Hayden, 1998; Lauenroth and others, 2014). Mean annual temperatures are highest in the southernmost SGP $\left(>16^{\circ} \mathrm{C}\right)$ with a decreasing gradient moving north and west (fig. $\left.2 A\right)$. A pronounced east-west gradient in precipitation is a major driver of Great Plains grassland community structure (Knapp and Seastedt, 1998; fig. 3A). Precipitation is lowest in western portions of the SGP (fig. 3A), where shortgrass species such as Bouteloua gracilis (blue grama) and B. dactyloides (formerly in the genus Buchloë; buffalograss) are dominant (Milchunas and others, 1989; Singh and others, 1998; Porensky and others, 2017). Precipitation is highest along the eastern side of the SGP supporting the western extent of tallgrass prairie (Briggs and Knapp, 1995; Knapp and Seasedt, 1998), where Andropogon gerardii (big bluestem) and Sorgastrum nutans (Indiangrass) are prevalent (Freeman, 1998) (figs. $1 A$ and 3A). Panicum virgatum (switchgrass) and Schizachryrium scoparium (little bluestem) are also common in the tallgrass prairie (Freeman, 1998).

In central portions of the SGP, variability in climate, soil, and topographic conditions has produced a mixture of short grasses, such as blue grama and buffalograss; mid-height grasses such as B. curtipendula (sideoats grama) and Schizachyrium scopoarium (little bluestem); and taller species, such as big bluestem and Indiangrass (Sims, 1988). The mixture of species and the variable structure they create are referred to as the mixed-grass and mid-grass prairies (hereafter referred to as mixed-grass prairie). Sandy soils, especially in the Sandhills of Nebraska, support short, mid-height and tall grasses of the sand prairie, including blue grama, little bluestem, Hesperostipa comata (needlegrass), Calamovilfla longifolia (prairie sandreed), Pascopyrum smithii (western wheatgrass) and Andropogon hallii (sand bluestem) (Barnes and Harrison, 1982; Sims, 1988). In the sand prairies of the SGP, Artemisia filifolia (sand sagebrush) and Quercus havardii (sand shinnery oak) co-occur with short, mid-height, and tallgrasses (Weaver and others, 1956; Reese and others, 2017), such as blue grama, sideoats grama, little bluestem, sand bluestem, Eragrostis trichodes (sand lovegrass), and Sporobolus cryptandrus (sand dropseed) (Berg and others, 1997; Harrell, and others, 2001; Gillen and Sims, 2004). The northern reach of semi-desert grasslands occurs along the southwestern margins of the SGP and LCD (fig. 1A). B. eriopoda (black grama) and Pleuraphis mutica (tobosagrass) are prevalent in semi-desert grasslands, in addition to Hilaria belangeri (curly-mesquite), Achnatherum hymenoides (Indian ricegrass), Muhlenbergia porteri (bush muhly), and Sporobolus flexuosus (mesa dropseed) (Sims 1988). Other, less common, grassland types found in the SGP (fig. 1A) include foothill and saline grasslands, northwest mixed-grass and cool season bunchgrass prairies (Reese, and others, 2017). 


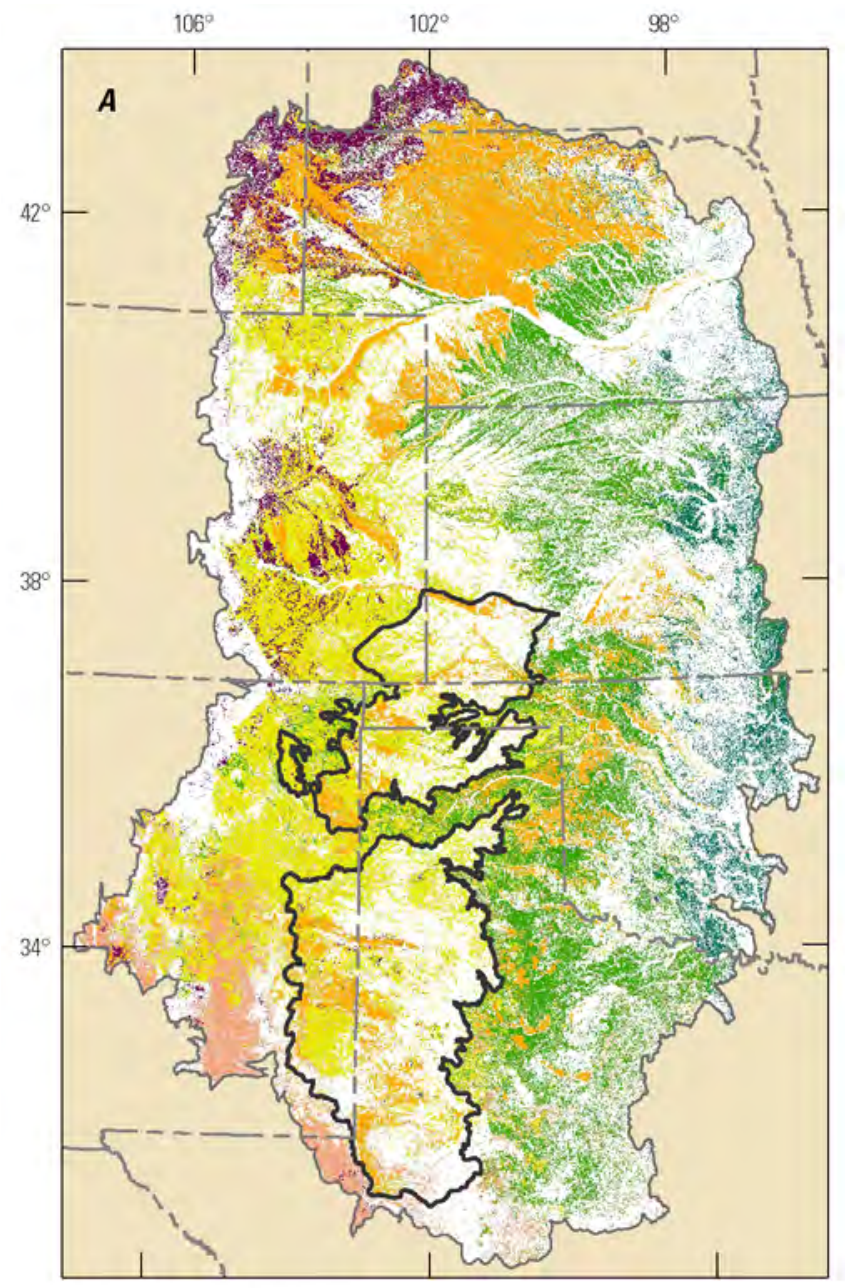

$0 \quad 100 \quad 200$ KILOMETERS $\underset{0}{1} \frac{1}{1} \underbrace{1}_{50} 100$ MILES

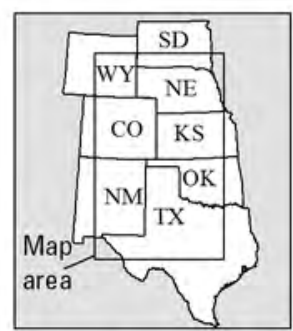

A. Grassland communities

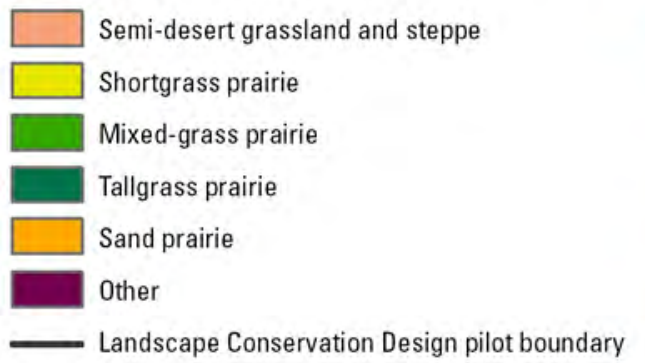

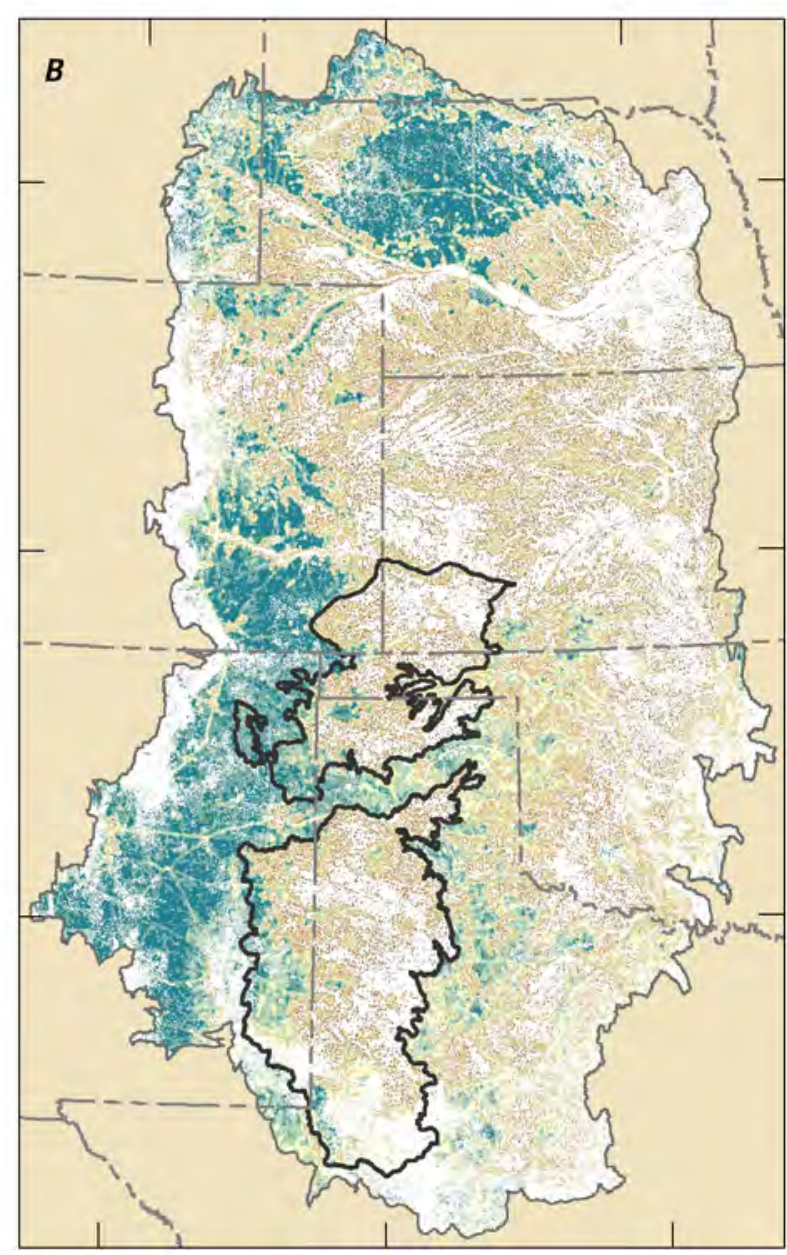

EXPLANATION

B. Terrestrial development index, in percent

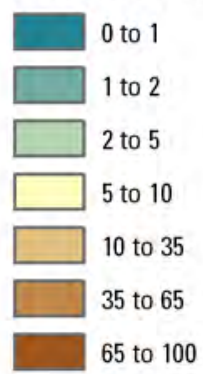

Base map from U.S. Geological Survey, National Map,1:12,635,439

North American Albers Equal Area Conic projection

North American Datum of 1983 , Central Meridian - $102^{\circ}$ W., Standard Parallels $20^{\circ} \mathrm{N}$. and $60^{\circ} \mathrm{W}$.

Figure 1. $A$, Grassland communities of the Southern Great Plains of the United States (modified from Reese and others, 2017), and $B$, spatial patterns of land use as represented by the terrestrial development index (TDI), as applied to grassland communities (modified from Reese and others, 2017). 


\section{Climate Scenarios}

General Circulation Models (GCM; also known as atmosphere-ocean general circulation models) have been created by multiple climate research institutions, coordinated by the Intergovernmental Panel on Climate Change (IPCC), based on established climate-science principles, testing, and refinement to provide credible estimates of potential future climate conditions (Randall and others, 2007). Four climate scenarios (warm-dry, warm-wet, hot-dry, and hot-wet) generated from GCMs were selected based on the projected departure from the average annual contemporary climate (1981-2010) for the SGP (derived from Maurer and others [2002]; figs. $2 A$ and $3 A$ ). The four climate scenarios (figs. 2 and 3; table 2) were derived from two greenhouse gas concentration scenarios (4.5 and 8.5 Representative Concentration Pathways [RCP] and GCM developed in the fifth phase of the Coupled Model Intercomparison Project [CMIP5], 2013).

To assist identification of four plausible climate scenarios, representatives of the U.S. Geological Survey (USGS) North Central Climate Adaptation Science Center (formerly North Central Climate Science Center) developed a bivariate distribution of mean temperature and precipitation conditions projected by different GCM-RCP combinations averaged across the GPLCC region. Four quadrants were defined to separate the distribution along each axis (temperature and precipitation) (Gross and others, 2016). Based on this distribution, and the intended purpose of the project, one GCM-RCP combination was selected to represent each climate scenario (table 2). GCM estimates of projected changes in precipitation vary widely, but inclusion of scenarios with a mean increase or decrease in precipitation allowed us to explore potential vulnerabilities to either possibility as is common in scenario planning (Gross and others, 2016).

Although longer-term projections from GCMs may include a broader range of precipitation and temperature changes than evaluated here, this project focused on more moderate, near-term changes (over the next 30 years). This was done to enable simulation of critical vulnerabilities for grasses that are relatively tolerant of high temperatures, while minimizing uncertainty associated with increasing divergence among climate projections and emission scenarios in the long term (for example, over the next 50-100 years). GCM scenarios were resampled from the source resolution to $150 \mathrm{~km}^{2}$ cells and mean annual temperature and total annual precipitation for each cell was averaged over a 30-year period - 2016 to 2045 (table 2).

There was temporal and spatial variation in the direction and magnitude of projected climate changes for the four scenarios (figs. 2 and 3). Overall, the mean annual temperatures for the warm scenarios were projected to increase 1 to $1.6^{\circ} \mathrm{C}(8.0$ to 12.8 percent), and the hot scenarios to increase 2.1 to $2.2^{\circ} \mathrm{C}$ (16.8 to 17.6 percent), compared to the contemporary climate (table 2). Overall, mean annual precipitation for the dry scenarios was projected to decrease 4.7 to $5.3 \mathrm{~cm}$ ( 8.5 to 9.5 percent) compared to the contemporary climate, and the hot-wet scenario was projected to increase $3.1 \mathrm{~cm}(5.6$ percent; table 2$)$. The mean annual precipitation for the warm-wet scenario was projected to be 2.1 to $2.7 \mathrm{~cm}$ (4.2 to 5.3 percent) greater than the dry scenarios, however this represents a decrease of $2.6 \mathrm{~cm}$ (4.7 percent) compared to the contemporary climate; consequently, the warm-wet scenario was actually drier than contemporary conditions in the near-term (the average warm-wet scenario projections were wetter than the contemporary climate by 2070). Furthermore, southern portions of the SGP were projected to be drier for the warm-wet scenario compared to the contemporary climate, whereas the northern portions were projected to be wetter (fig. $3 B$ ).

Table 2. Mean temperature and precipitation, and horizontal resolution of the sources, for the contemporary climate and the four climate scenarios evaluated for the Southern Great Plains of the United States.

$\left[{ }^{\circ} \mathrm{C}\right.$, degrees Centigrade; cm, centimeters $]$

\begin{tabular}{lllcccc}
\hline \multicolumn{1}{c}{ Time period } & $\begin{array}{c}\text { Climate condition } \\
\text { or scenario }\end{array}$ & Data source & $\begin{array}{c}\text { Mean annual } \\
\text { temperature }\left({ }^{\circ} \mathbf{C}\right)\end{array}$ & $\begin{array}{c}\text { Mean annual } \\
\text { precipitation }(\mathbf{c m})\end{array}$ & $\begin{array}{c}\text { Longitude resolution } \\
\text { (degrees) }\end{array}$ & $\begin{array}{c}\text { Latitude resolution } \\
\text { (degrees) }\end{array}$ \\
\hline 1981-2010 & Contemporary & $\begin{array}{c}\text { Maurer and } \\
\text { others (2002) }\end{array}$ & 12.5 & 55.5 & 0.125 & 0.125 \\
$2016-2045$ & Warm-dry & GISS-E2-R & 13.5 & 50.8 & 2.5 & 2.0 \\
$2016-2045$ & Warm-wet & CESM1-BGC & 14.1 & 52.9 & 1.4 & 1.4 \\
$2016-2045$ & Hot-dry & ACCESS 1-0 & 14.7 & 50.2 & 1.875 & 1.25 \\
$2016-2045$ & Hot-wet & Miroc-ESM & 14.6 & 58.6 & 2.8 & 2.8 \\
\hline
\end{tabular}

${ }^{1}$ Carbon dioxide emission scenario RCP4.5 (representative concentration pathway) was used for both warm scenarios. RCP8.5 was used for both hot scenarios.

${ }^{2}$ GISS-E2-R, National Aeronautics and Space Administration (NASA); Goddard Institute for Space Studies (GISS) (Schmidt and others, 2014)

${ }^{3}$ CESM1-BGC, The Community Earth System Model; Lawrence Berkeley National Laboratory and National Center for Atmospheric Research (NCAR) (Neale and others, 2012)

${ }^{4}$ ACCESS 1-0, The Australian Community Climate and Earth-System Simulator, Australian Government, Bureau of Meteorology, Australia (Collier and Uhe, 2012)

${ }^{5}$ Miroc-ESM, Center for Climate System Research, University of Tokyo, National Institute for Environmental Studies and Frontier Research Center for Global Change, Japan (Watanabe and others, 2011) 

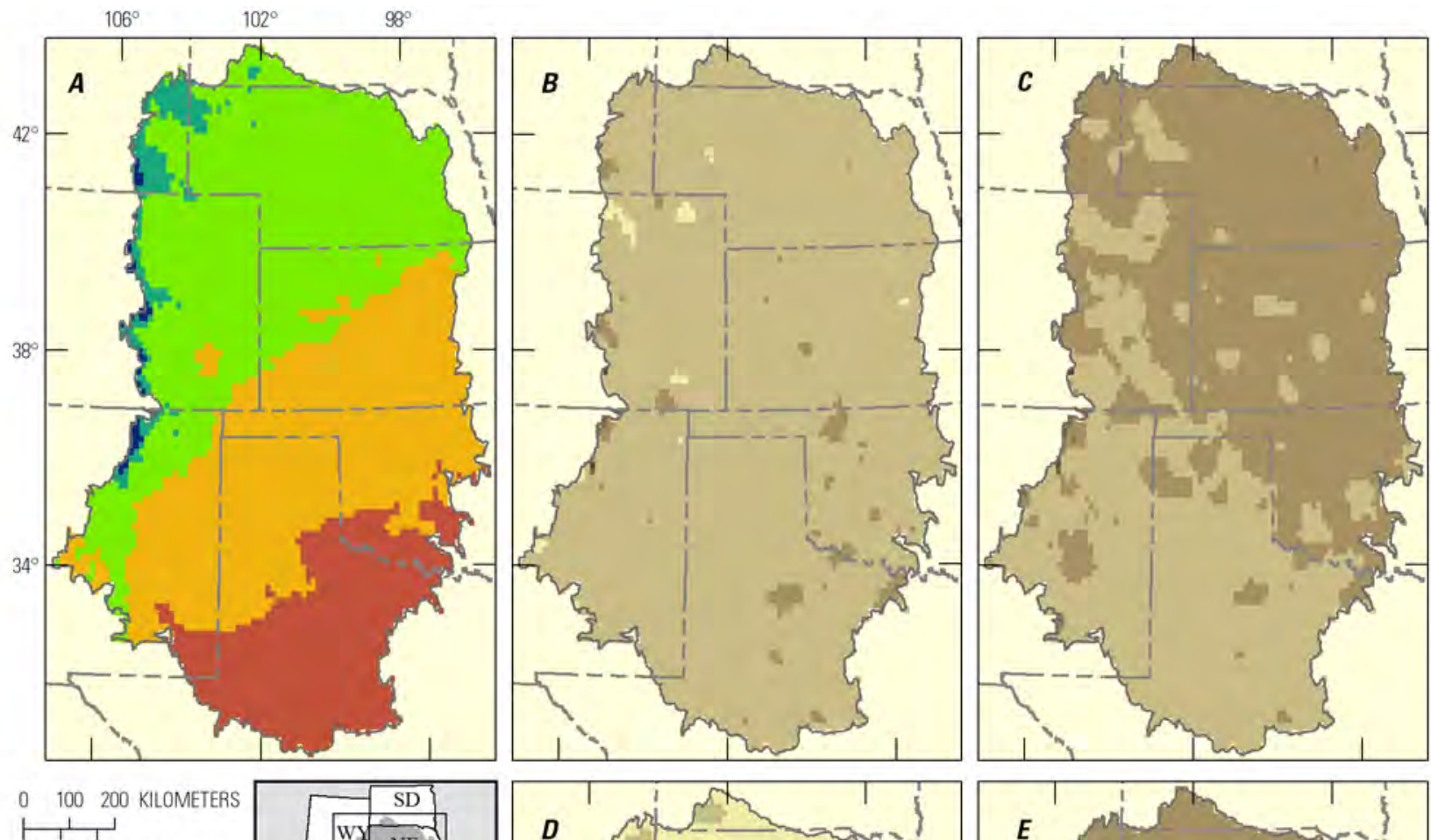

$0 \quad 50100$ MLLES
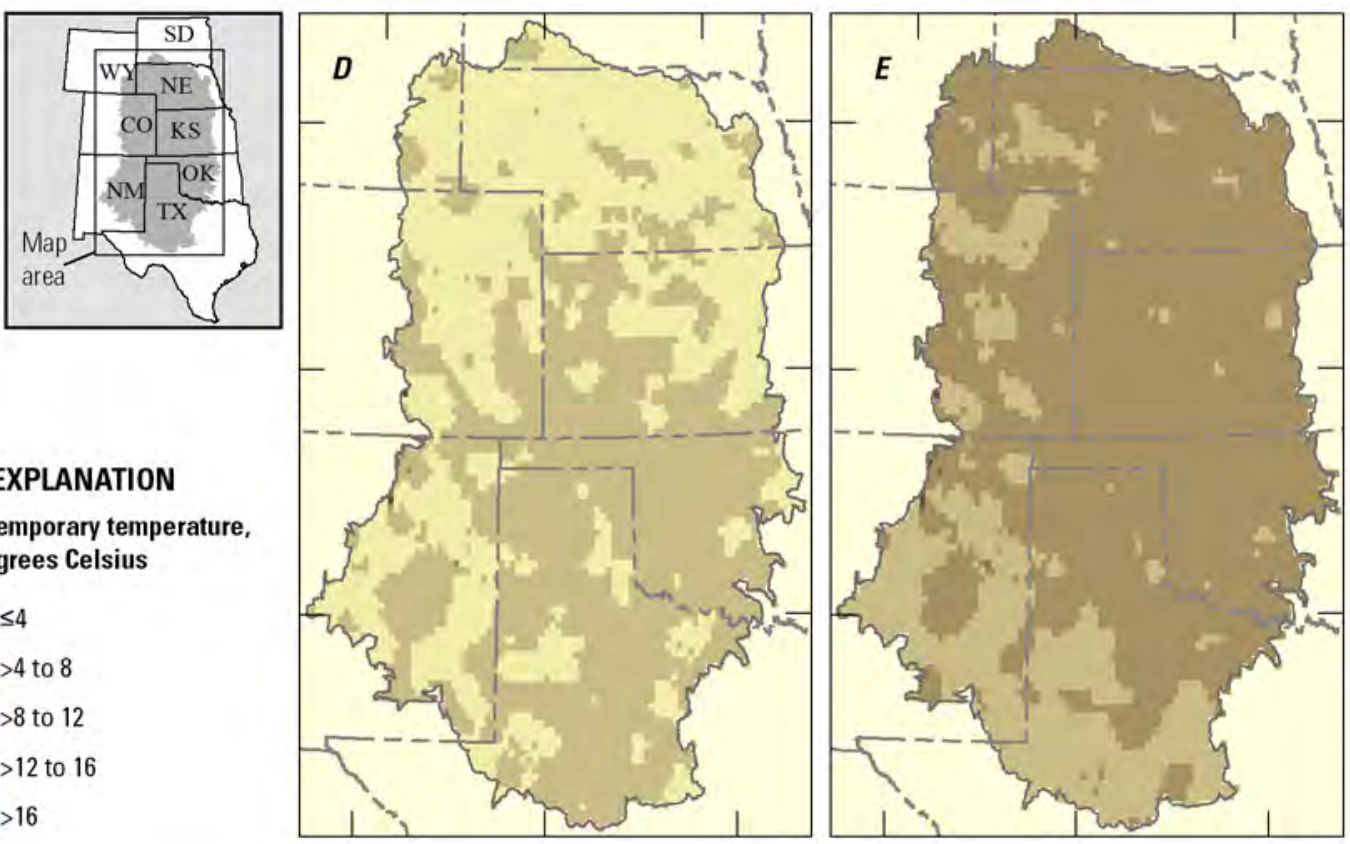

EXPLANATION

A. Contemporary temperature, in degrees Celsius

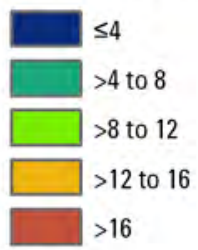

Base map from U.S. Geological Survey National Map, 1:18,883,014 North American Albers Equal Area Conic projection

EXPLANATION

B-E. Projected change in temperature, in degrees Celsius

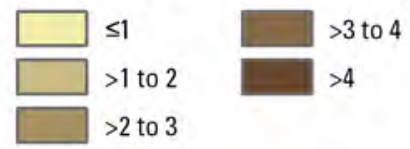

Figure 2. Mean temperature for the contemporary climate and the changes projected for four climate scenarios compared to contemporary temperatures for the Southern Great Plains of the United States. A, Average contemporary annual temperature (1981-2010); projected changes in temperature for 2016-2045 relative to contemporary annual temperatures (A) for: $B$, warm-wet; $C$, hot-wet; $D$, warm-dry; and $E$, hot-dry. See table 1 for the general circulation model used for each climate scenario. 

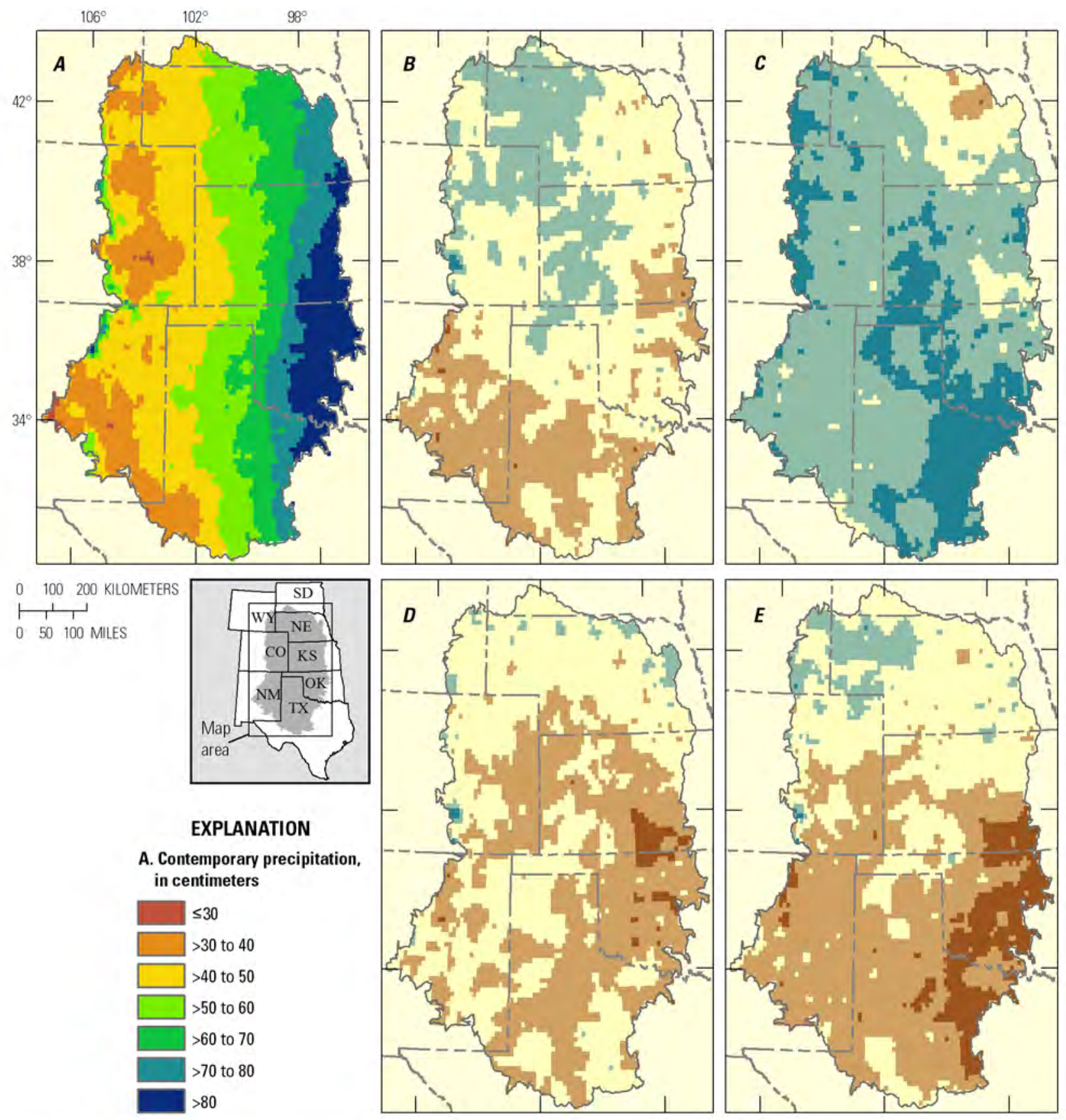

Base map from U.S. Geological Survey National Map,1:18,883,014 North American Albers Equal Area Conic projection

EXPLANATION

North American Datum of 1983 , Central Meridian $-102^{\circ} \mathrm{W}$.

Standard Parallels $20^{\circ} \mathrm{N}$. and $60^{\circ} \mathrm{W}$.

B-E. Projected change in precipitation, in centimeters

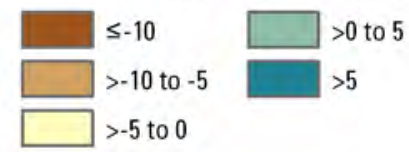

Figure 3. Mean precipitation for the contemporary climate and the changes projected for four climate scenarios compared to contemporary precipitation for the Southern Great Plains of the United States. A, Average contemporary annual precipitation (1981-2010); projected changes in precipitation for 2016-2045 relative to contemporary annual precipitation (A) for: $B$, warm-wet; $C$, hot-wet; $D$, warm-dry; and $E$, hot-dry. See table 1 for the general circulation model used for each climate scenario. 


\section{Grassland Species Productivity Modeling}

\section{Indicator Species}

Two indicator species for each of the four focal grassland communities - semi-desert grasslands, and shortgrass, mixedgrass, and tallgrass prairies - were selected from the species modeled by Epstein and others (1998; table 3). Although most of these species are not restricted to a single community type, they can be useful, in combination, for representing the potential for change in composition affecting key structural features (such as, average grass height) of the focal grassland communities. For this reason, we evaluated each species with respect to the associated grassland community as well as for the entire extent of the SGP.

The models (Epstein and others, 1998) indicated that the species vary from a weak negative to a strong positive correspondence between relative productivity and precipitation (table 3). The models also indicated that productivity for all species was positively associated with temperature. In addition, blue grama and big bluestem productivity had nonlinear relations with temperature, as did sideoats grama with precipitation, as indicated by quadratic terms in the models (table 3 ).

\section{Productivity Models}

To map the bioclimatic conditions suitable for each indicator species, climate and soil texture predictor variables were applied to the models developed by Epstein and others (1998) (table 3) for each cell in the SGP. Relative primary productivity standardizes the data on a scale between 0 and 100, based on the amount of biomass for each species relative to the site total derived from field samples (Epstein and others, 1998). Relative primary productivity is a quantitative index of above ground biomass produced by the species at any given location; larger values indicate greater above ground biomass. For each indicator species, relative primary productivity was estimated for the contemporary climate (hereafter referred to as contemporary productivity) and was predicted for each climate scenario (hereafter referred to predicted productivity) (table 2; figs. 2 and 3) using generalized linear models (GLM) of the relationship between productivity and the predictor variables (table 3). Soil conditions were quantified using raster data $(10 \times 10$-meter $[\mathrm{m}]$ grid) for each soil component (Earth System Science Center, 2016). Soil texture, expressed as the percent of each particle class (for example, sand, silt and clay) by weight in a representative sample of the soil type (Schoeneberger, and others, 2002), was constant in all models, because soils typically change slowly and predicted changes in soil texture were not available.

Table 3. Predictor variables and associated parameters for grassland indicator species used to model relative productivity for the Southern Great Plains of the United States. Models from Epstein and others (1998). Species height data from Natural Resources Conservation Service (2017).

[in., inch; Temp, mean annual temperature; Precip, mean annual precipitation; (Temp) ${ }^{2}$, heading superscript "2" indicates nonlinear response to temperature; (Precip) $)^{2}$, heading superscript "2" indicates nonlinear response to precipitation; - , does not appear in this model.]

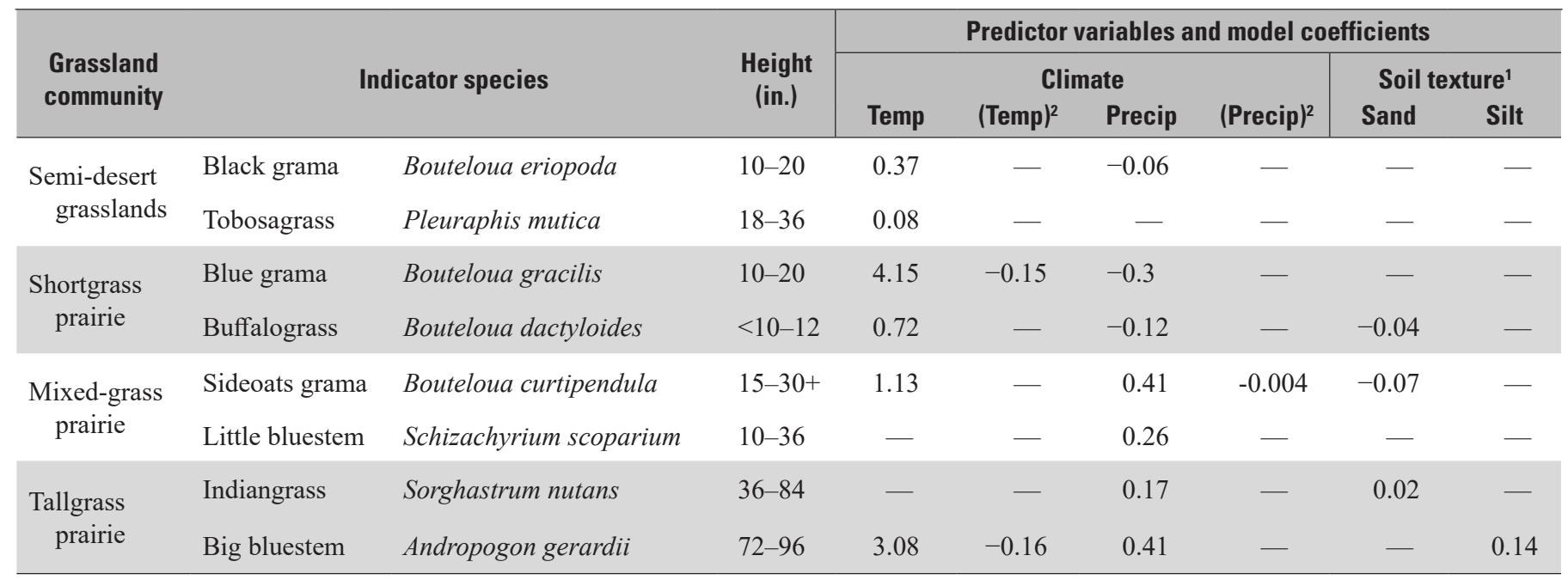

${ }^{1}$ None of the models for the indicator species included clay as a predictor variable. 
The differences between predicted and contemporary productivity (see appendix 1) were used to evaluate the predicted changes in productivity for each indicator species (figs. 4-11). We quantified the magnitude of changes in mean productivity and classified those results using breakpoints between classes corresponding to intervals of one standard deviation in the distribution of predicted change. This classification was used to facilitate interpretation of potential changes in productivity across the SGP and to reduce interpretation errors as a result of uncertainty inherent in model results. To evaluate potential for changes in each focal grassland community, we examined spatial concurrence of predicted changes in productivity among indicator species within the current distribution of the corresponding grassland community (figs. 12-16).

\section{Quantifying Current Land Use}

To evaluate the cumulative effects of development (croplands, roads, energy, minerals, and urban areas) on the capacity of grassland communities to adapt to divergent potential climates, we used the terrestrial development index (TDI) from the Southern Great Plains Rapid Ecoregional Assessment (Reese and others, 2017). The TDI summarizes the surface disturbance footprint from development within a $2.5-\mathrm{km}$ radius (Reese and others, 2017). Scores range from 0 to 100 percent, and low scores (for example, TDI $\leq 5$ percent) indicate relatively undeveloped areas on the landscape (fig. $1 B$ ). The TDI scores for each grassland community, all SGP grasslands combined, and the LCD project area were used as an indicator of development levels (fig. 17).

\section{Results}

The model results presented here depict the potential productivity of the species using the modeled relations between contemporary climate, or climate scenarios, and soil conditions across the entire region. The model results for the contemporary distribution were classified to correspond, approximately, to field observations, but the results of the scenario models were not spatially restricted to current distributions. Thus, the models may depict production potential in areas where the species does not occur, or may not occur in the future, due to land use or dispersal limitations, for example. Providing results across the entire region allows readers to recognize how changes in climate may affect potential suitability for the species across the region without assumptions about where, or how far, a species might disperse.

Although most of the indicator species selected are not restricted to a single grassland community, the greatest contemporary productivity for each species generally corresponded to only one or two community types (figs. 4-11). However, the two indicator species for the mixed-grass prairies are common outside of these communities; sideoats grama is common in shortgrass prairie and little bluestem is common in tallgrass prairie, and the two shortgrass species-blue grama and buffalograss-occur in many communities beyond the shortgrass prairie. 


\section{Semi-Desert Grassland Species}

\section{Tobosagrass}

Contemporary productivity for tobosagrass was greatest in the southernmost SGP (fig. $4 A$ ) generally corresponding to its current distribution, which is largely restricted to semi-desert grasslands (fig. $1 A$ ). Contemporary productivity was greatest within the southernmost extent of the LCD and was generally low throughout much of the LCD. The climate conditions conducive for tobosagrass were predicted to increase throughout the LCD and across the entire SGP for all four climate scenarios, indicating limited sensitivity and potential for adaptive capacity to be high for this species based on these scenarios (fig. $4 B-E$ ).

\section{Black Grama}

Contemporary productivity of black grama was greatest in the southwestern extent of the SGP and the LCD corresponding to its current distribution in semi-desert grasslands (fig. 5A). The climate conditions suitable for black grama were predicted to increase throughout the LCD and SGP for all four climate scenarios (fig. $5 B-E$ ). The regions exhibiting the greatest predicted increase in black grama productivity (fig. 5) corresponded to the greatest projected decreases in precipitation (fig. $3 B-E$ ). The hot-wet scenario showed the lowest predicted increase in productivity compared to the other scenarios. Based on these patterns, sensitivity to the climate scenarios evaluated is expected to be relatively low and potential adaptive capacity to be high for black grama.

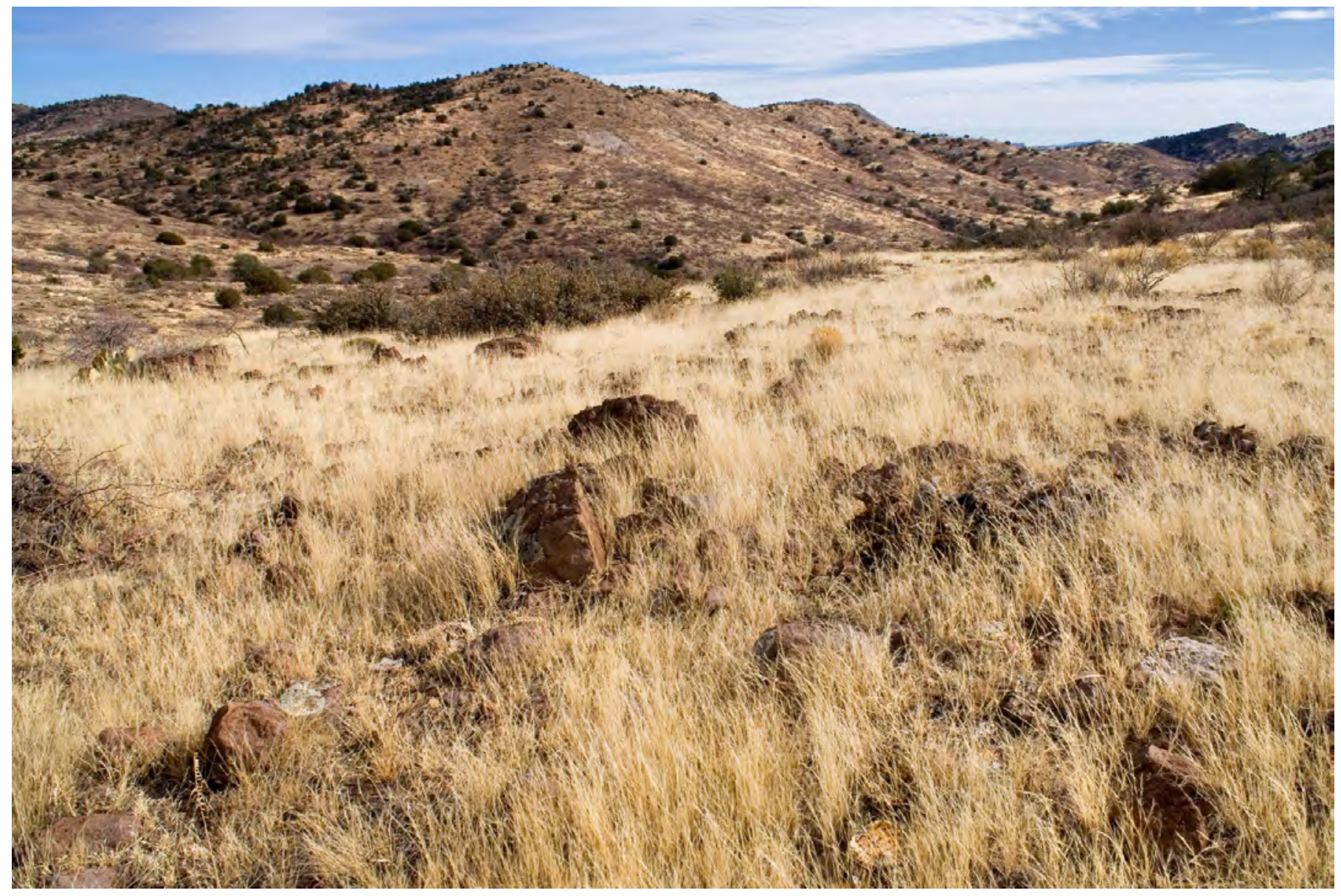



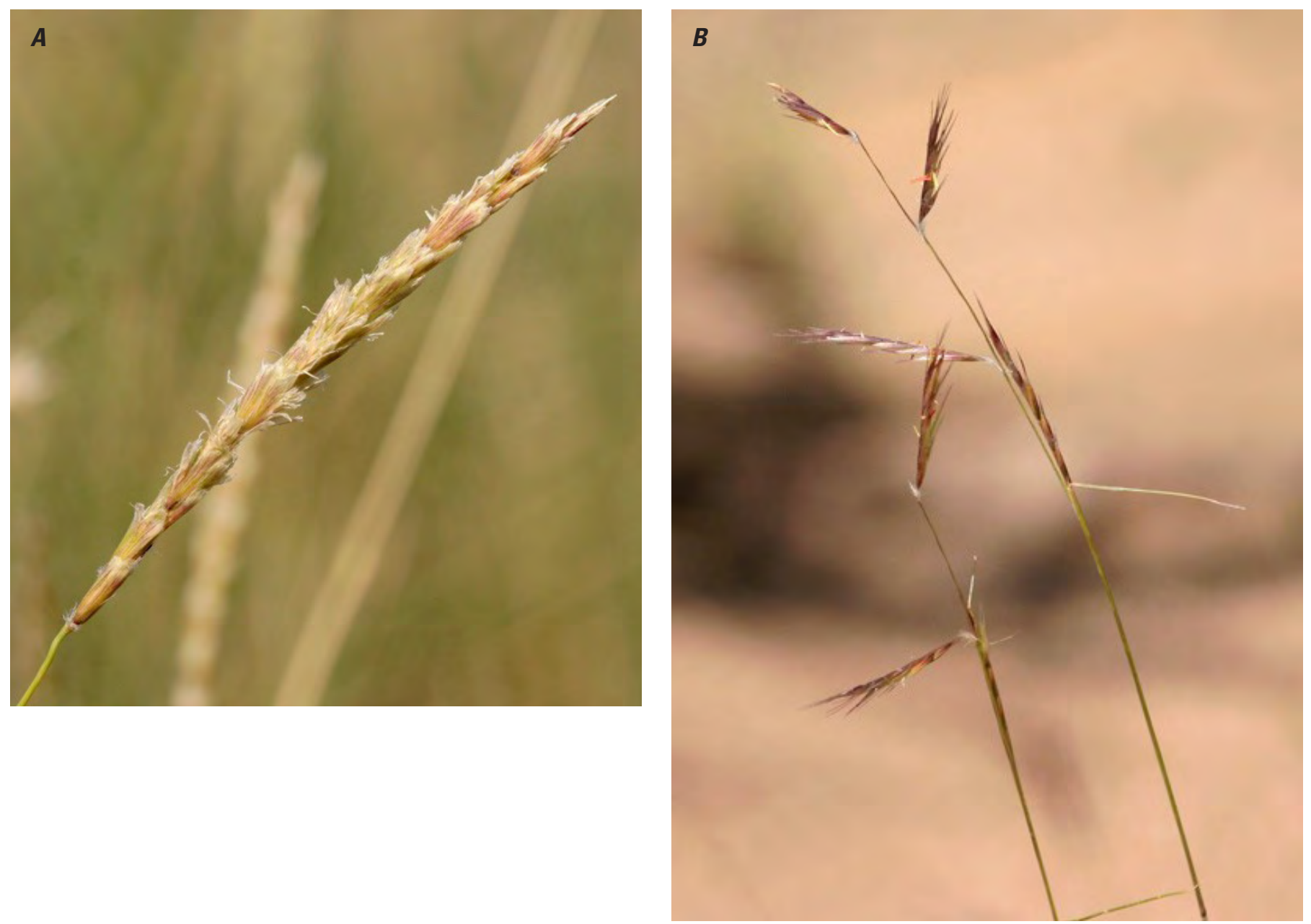

A, Pleuraphis mutica (tobosagrass). Photograph by Patrick J. Alexander. Hosted by the U.S. Department of Agriculture, Natural Resources Conservation Service (NRCS), PLANTS database. B, Bouteloua eriopoda (black grama). Photograph by Patrick J. Alexander. Hosted by the U.S. Department of Agriculture, Natural Resources Conservation Service (NRCS), PLANTS database. Productivity suitable for indicator species for semi-desert grasslands was predicted to expand for all climate scenarios evaluated. 

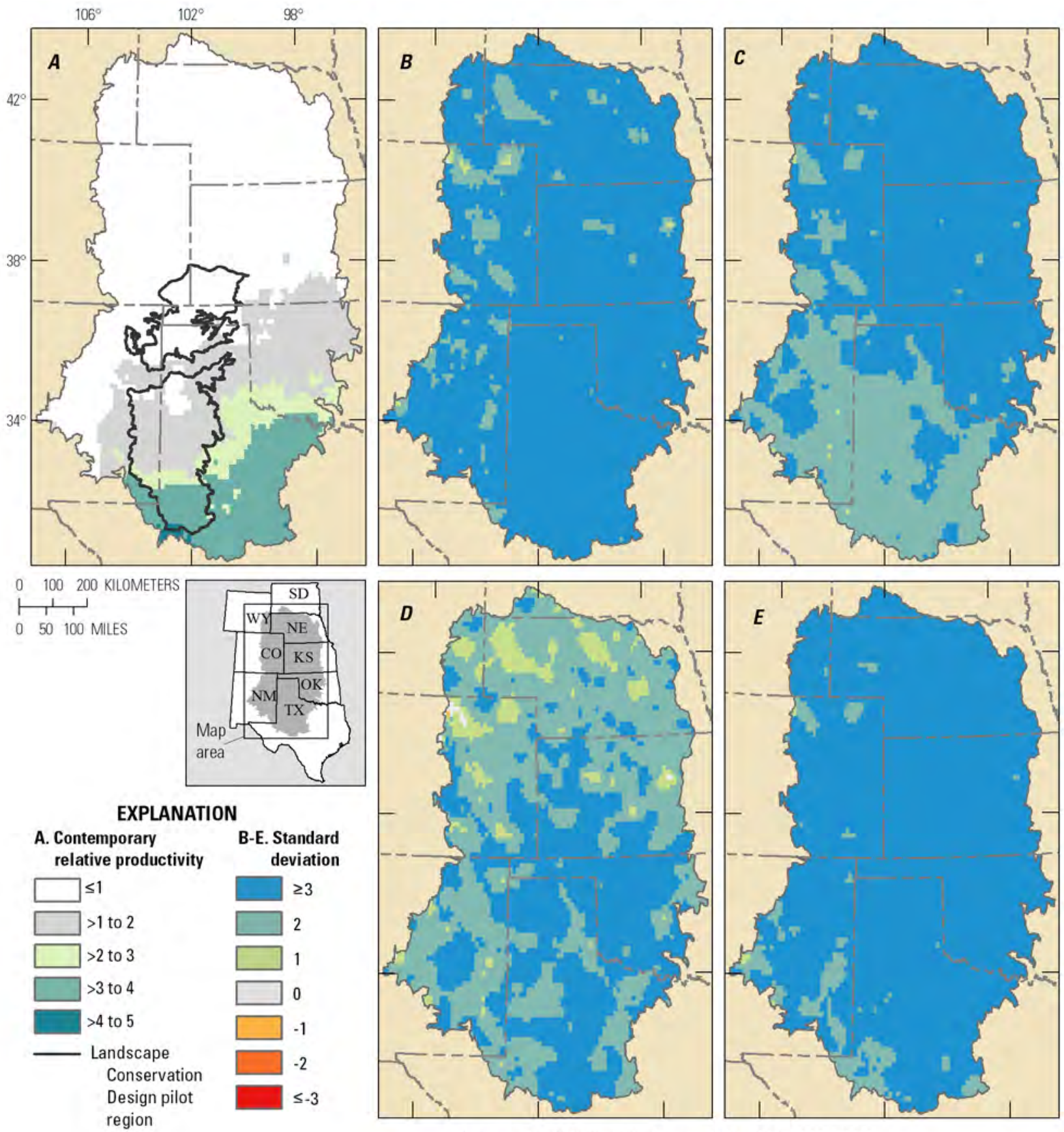

Base map from U.S. Geological Survey, National Map,1:18,883,014

North American Albers Equal Area Conic projection

North American Datum of 1983 , Central Meridian $-102^{\circ}$ W., Standard Parallels $20^{\circ} \mathrm{N}$. and $60^{\circ} \mathrm{W}$.

Figure 4. Difference in the predicted relative productivity of Pleuraphis mutica (tobosagrass) an indicator species for semi-desert grasslands, as modeled using four climate scenarios in the Southern Great Plains of the United States. $A$, Contemporary relative productivity of tobosagrass. Predicted change in relative productivity of tobosagrass for each climate scenario in comparison to contemporary relative productivity for: $B$, warm-wet $C$, hot-wet $D$, warm-dry and $E$, hot-dry conditions. 

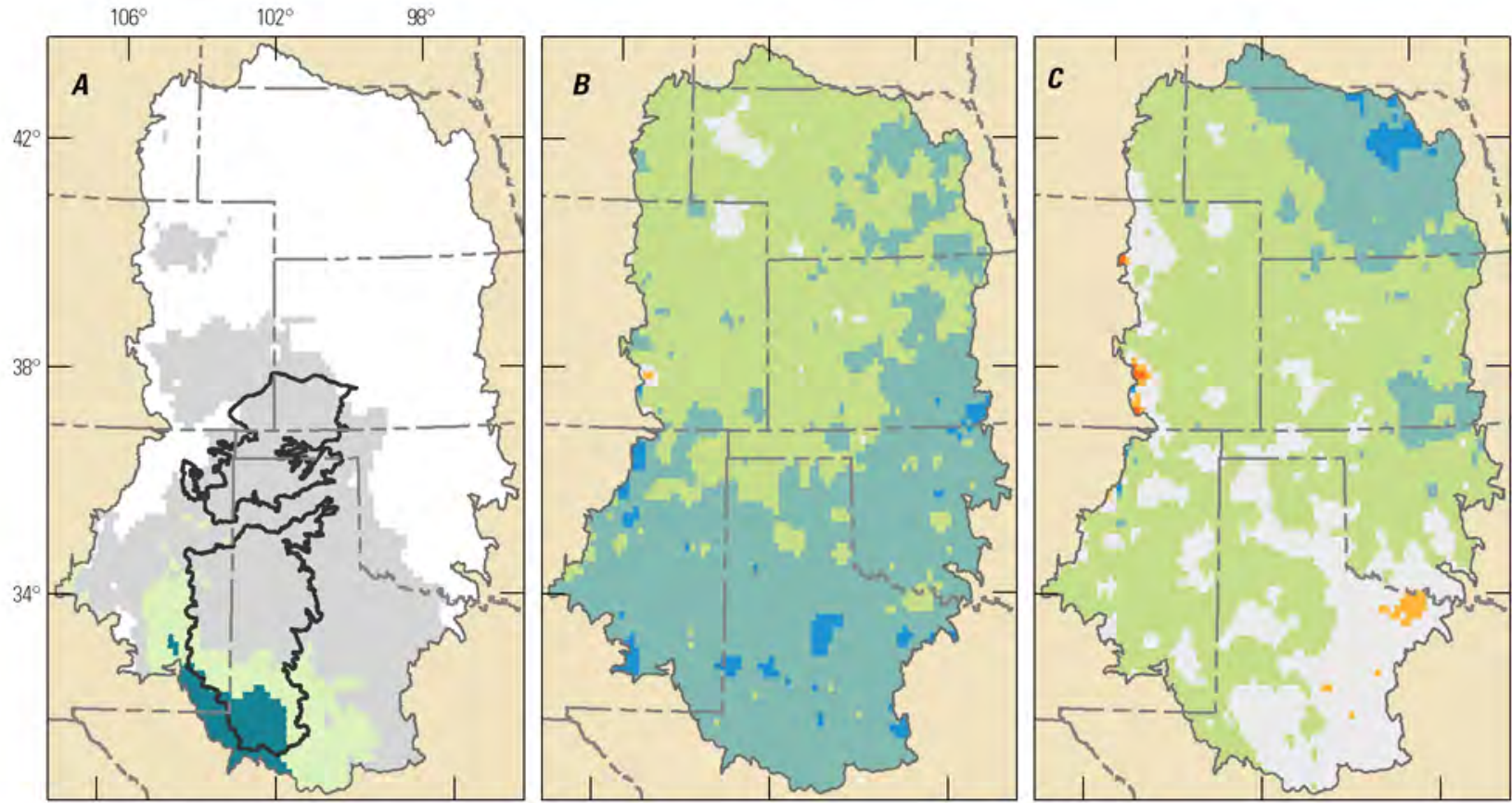

$0 \quad 100200$ KILOMETERS $\longmapsto, 1$,

$0 \quad 50100$ MLLES
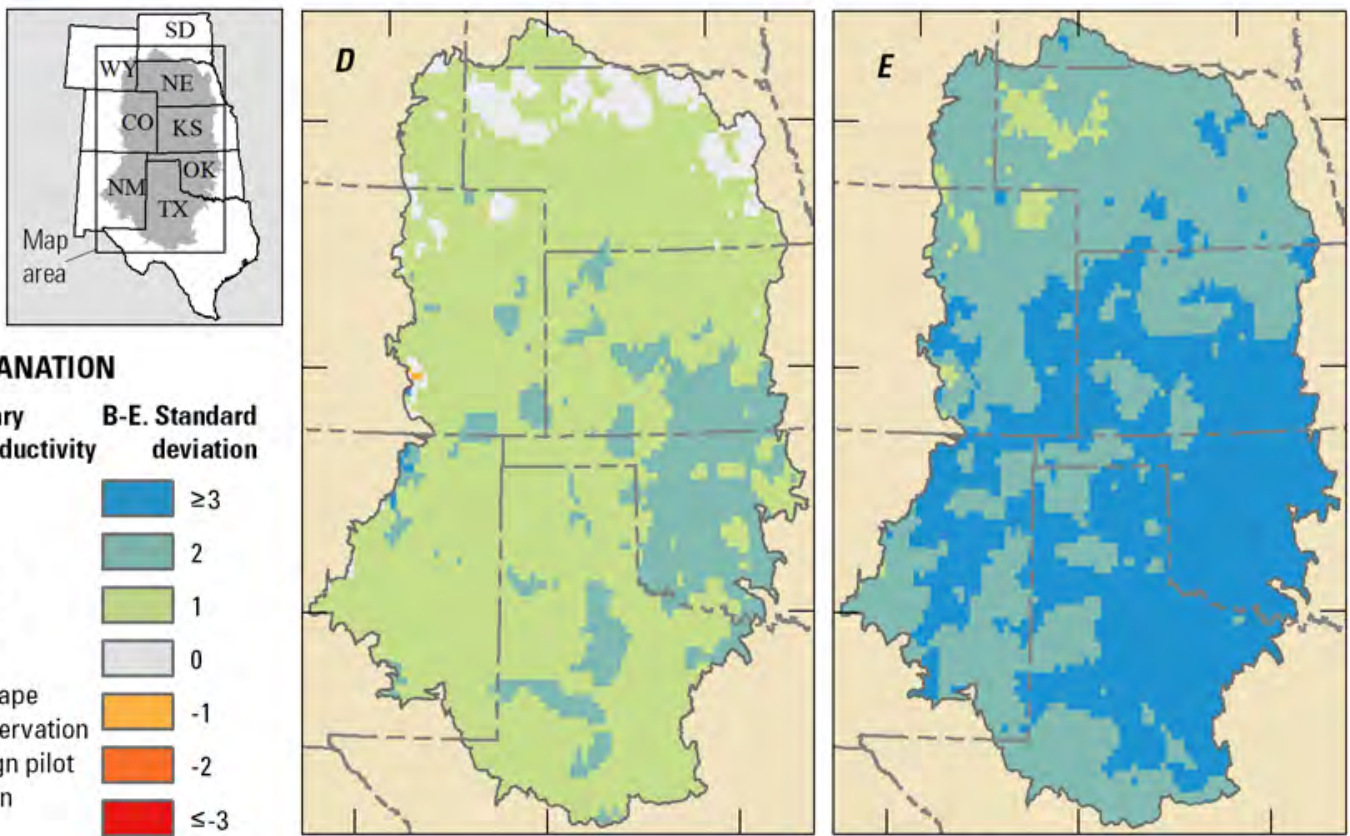

A. Contemporar

B-E. Standard relative productivity

\begin{tabular}{|c|}
\hline$\leq 2$ \\
\hline$>2$ to 4 \\
\hline$>4$ to 6 \\
\hline$>6$ to 9 \\
\hline $\begin{array}{l}\text { Landscape } \\
\text { Conservation }\end{array}$ \\
\hline $\begin{array}{l}\text { Design pilot } \\
\text { region }\end{array}$ \\
\hline
\end{tabular}

Base map from U.S. Geological Survey, National Map, 1:18,883,014

North American Albers Equal Area Conic projection

North American Datum of 1983 , Central Meridian $-102^{\circ}$ W., Standard Parallels $20^{\circ} \mathrm{N}$. and $60^{\circ} \mathrm{W}$.

Figure 5. Difference in the predicted relative productivity of Bouteloua eriopoda (black grama), an indicator species for semi-desert grasslands, as modeled using four climate scenarios in the Southern Great Plains of the United States. $A$, Contemporary relative productivity of black grama. Predicted change in relative productivity of black grama for each climate scenario in comparison to contemporary relative productivity for: $B$, warm-wet; $C$, hot-wet; $D$, warm-dry; and $E$, hot-dry conditions. 


\section{Shortgrass Prairie}

\section{Blue Grama}

Contemporary productivity for blue grama was greatest along the eastern SGP and across the entire LCD (fig. 6A), corresponding to the current distribution of shortgrass prairie (fig. $1 A$ ). The productivity of blue grama was predicted to remain relatively stable or increase within the current distribution of shortgrass prairie for all climate scenarios except the hot-wet scenario (fig. $6 C$ ). For both dry scenarios (fig. $6 D$ and $E$ ), productivity was predicted to increase across the SGP, whereas productivity for both wet scenarios was predicted to remain stable throughout most of the SGP except in the southeastern portions of the SGP where it was projected to decline (fig. $6 B$ and $C$ ). The predicted decline in productivity for the hot-wet scenario falls within the southeast extent of the shortgrass prairie for the SGP and the LCD. Otherwise, the predicted declines in productivity are outside of the current extent of the shortgrass prairie. Sensitivity to the climate scenarios is expected to be relatively low and adaptive capacity relatively high for blue grama, based on these scenarios.

\section{Buffalograss}

Contemporary productivity for buffalograss was greatest in the southern half of the SGP and throughout the LCD, corresponding to the current distribution of shortgrass prairie as well as semi-desert grasslands and southern portions of the mixed-grass prairie (figs. $1 A$ and $7 A$ ). The productivity of buffalograss was predicted to be stable or increase for all four climate scenarios (fig. $7 B-E$ ). Therefore, sensitivity to the four climate scenarios was interpreted to be low and potential for high adaptive capacity for buffalograss across the region.

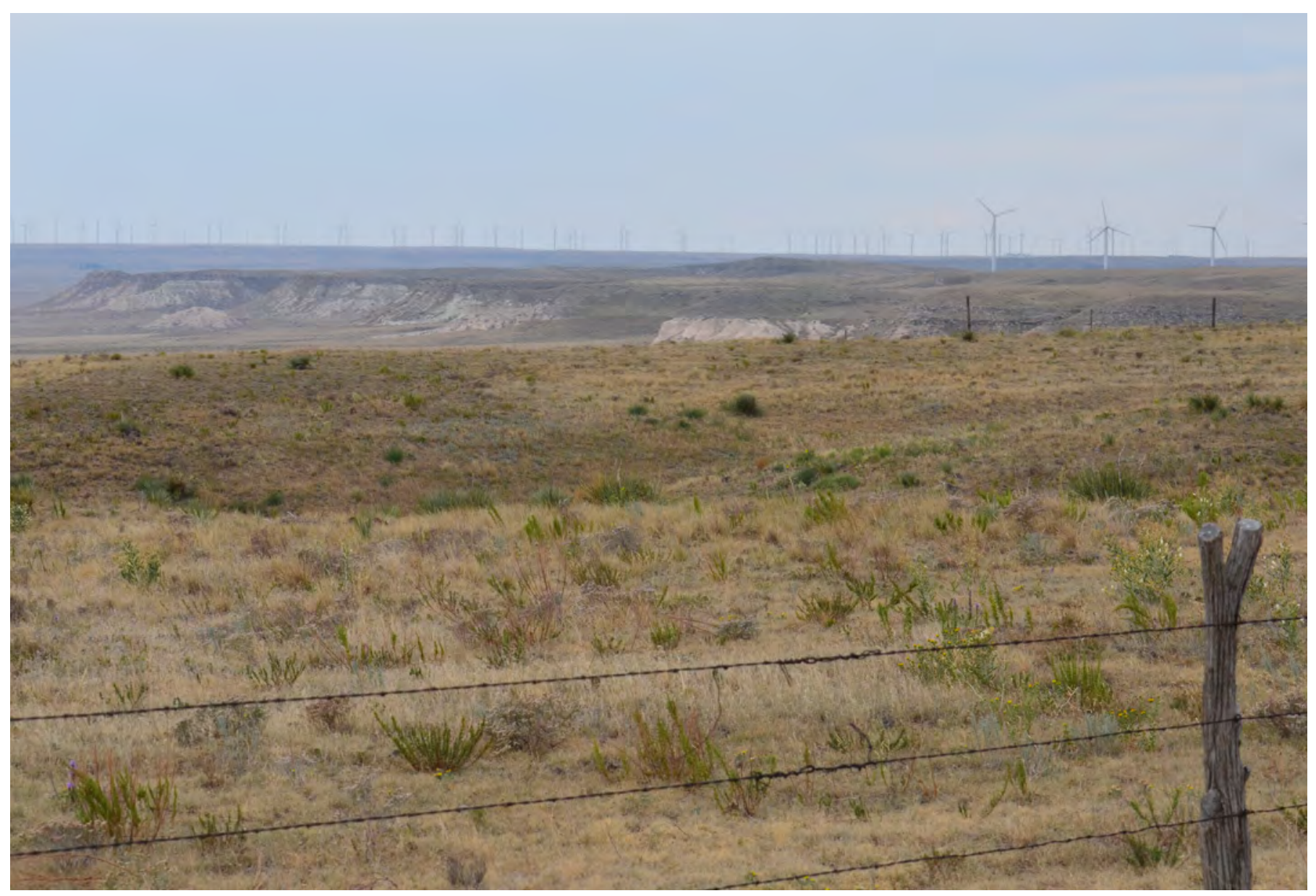

Wind turbines in shortgrass prairie, Pawnee Buttes, Colorado. Photograph by Natasha Carr, U.S. Geological Survey. 

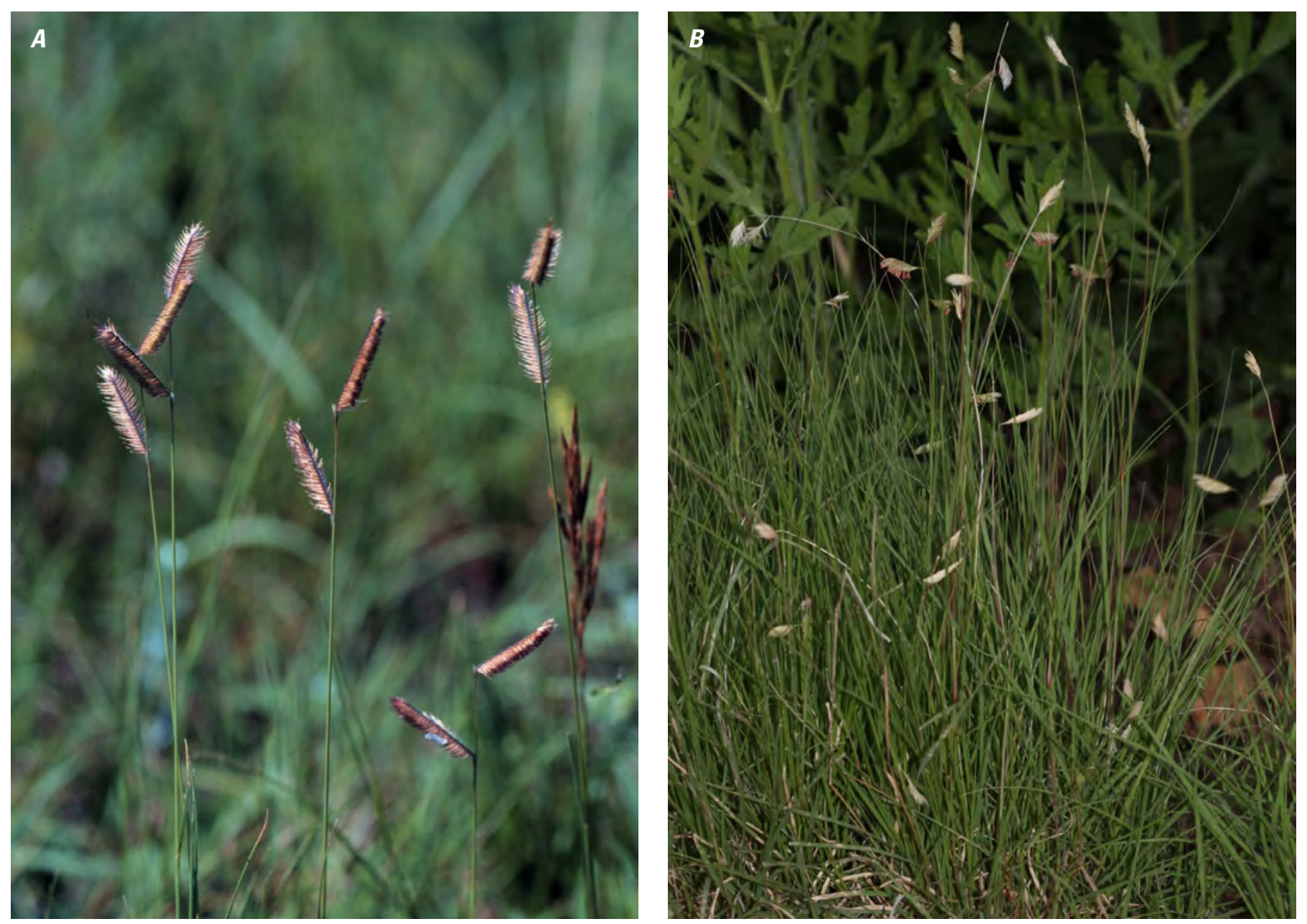

A, Bouteloua gracilis (blue grama). Photograph by Larry Allain, U.S. Geological Survey National Wetlands Research Center. Hosted by the U.S. Department of Agriculture, Natural Resources Conservation Service (NRCS), PLANTS database. B,Bouteloua dactyloides (buffalograss) in Red Butte Garden, Salt Lake City, Utah. Photograph by Andrey Zharkikh, Flickr, July 13, 2011. Productivity suitable for one or both indicator species for shortgrass prairie was predicted to expand for all climate scenarios evaluated. 

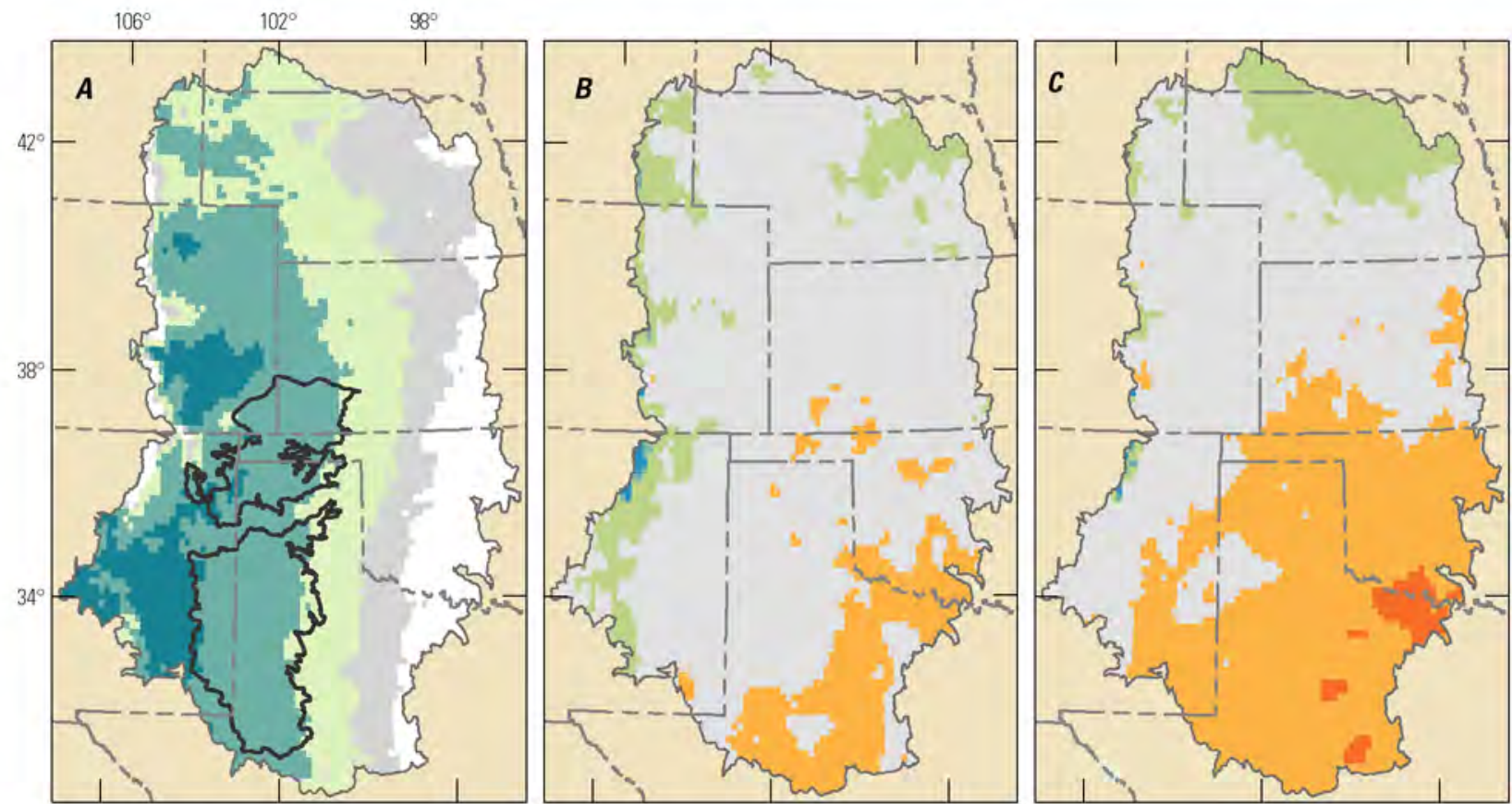

$0 \quad 100200$ KILOMETERS $\longmapsto, 1,1$

$0 \quad 50100$ MILES

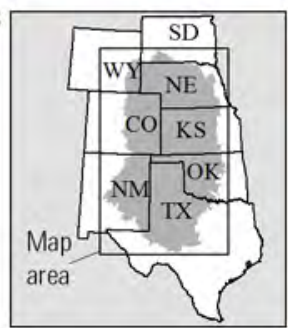

EXPLANATION

A. Contemporary relative productivity

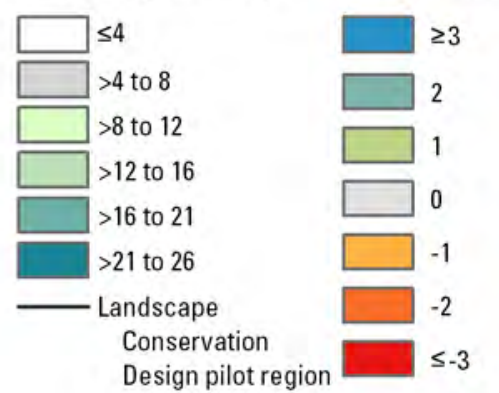

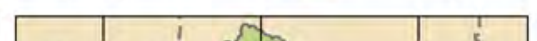
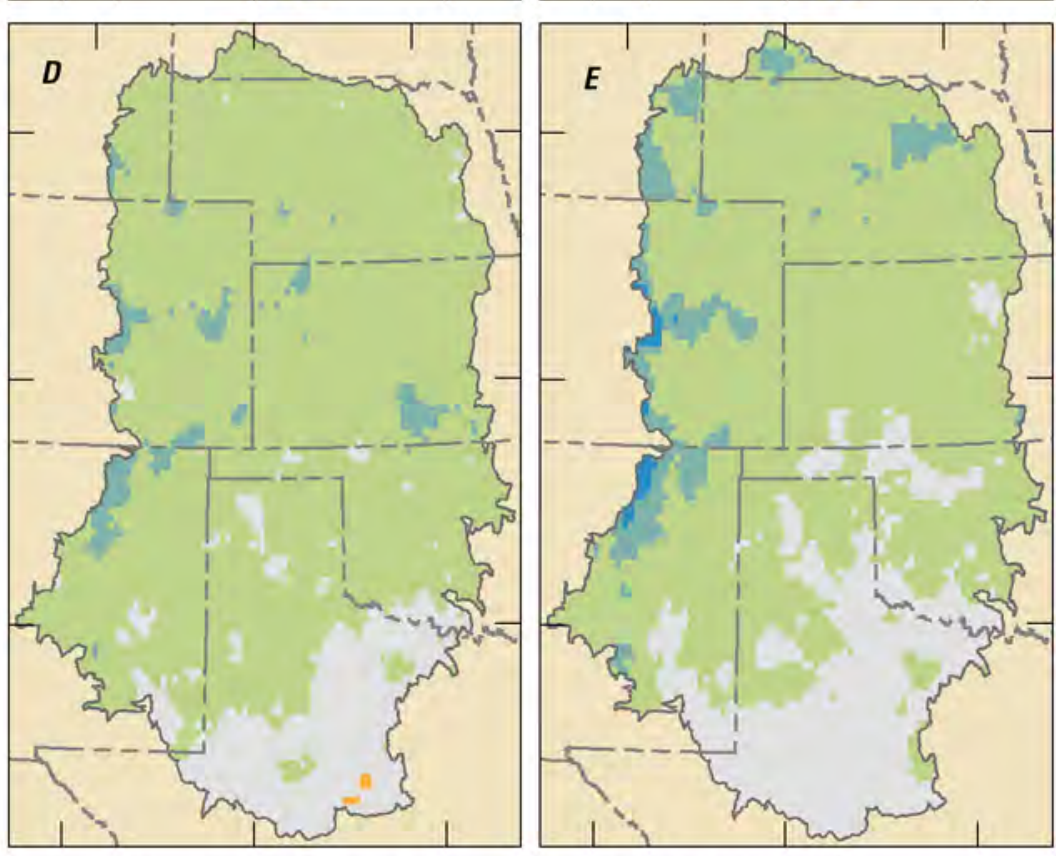

Base map from U.S. Geological Survey, National Map,1:18,883,014 North American Albers Equal Area Conic projection

North American Datum of 1983 , Central Meridian $-102^{\circ}$ W., Standard Parallels $20^{\circ} \mathrm{N}$. and $60^{\circ} \mathrm{W}$.

Figure 6. Difference in the predicted relative productivity of Bouteloua gracilis (blue grama), an indicator species for shortgrass prairie, as modeled using four climate scenarios in the Southern Great Plains of the United States. $A$, Contemporary relative productivity of blue grama. Predicted change in relative productivity of blue grama for each climate scenario in comparison to contemporary relative productivity for: $B$, warm-wet; $C$, hot-wet; $D$, warm-dry; and $E$, hot-dry conditions. 

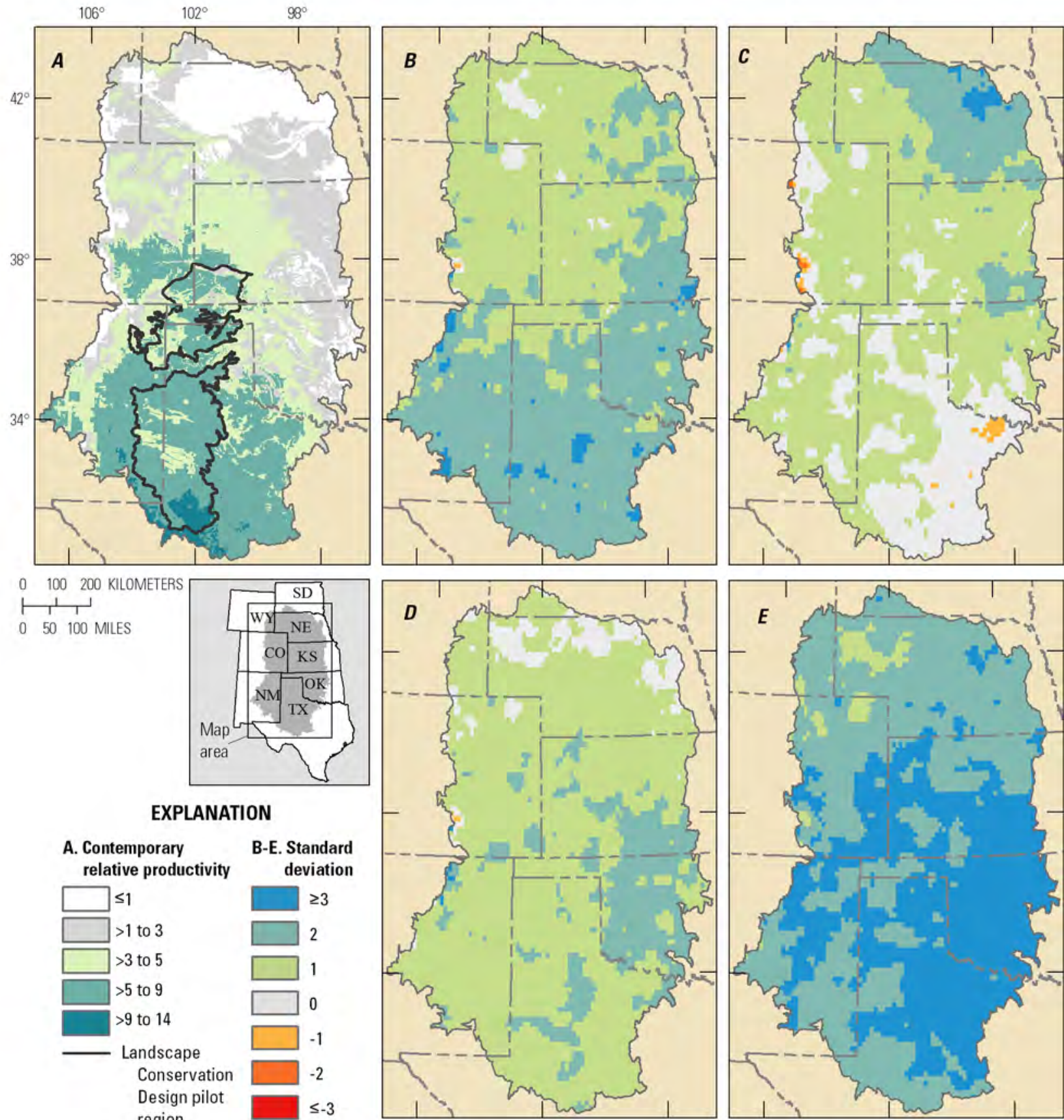

A. Contemporary

EXPLANATION relative productivity

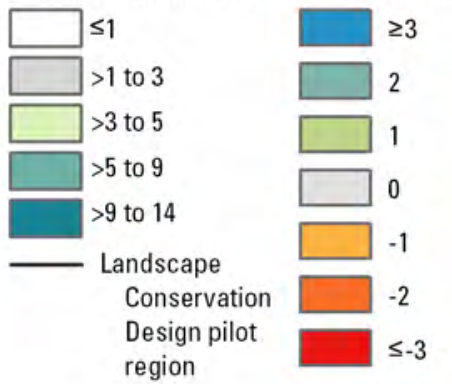
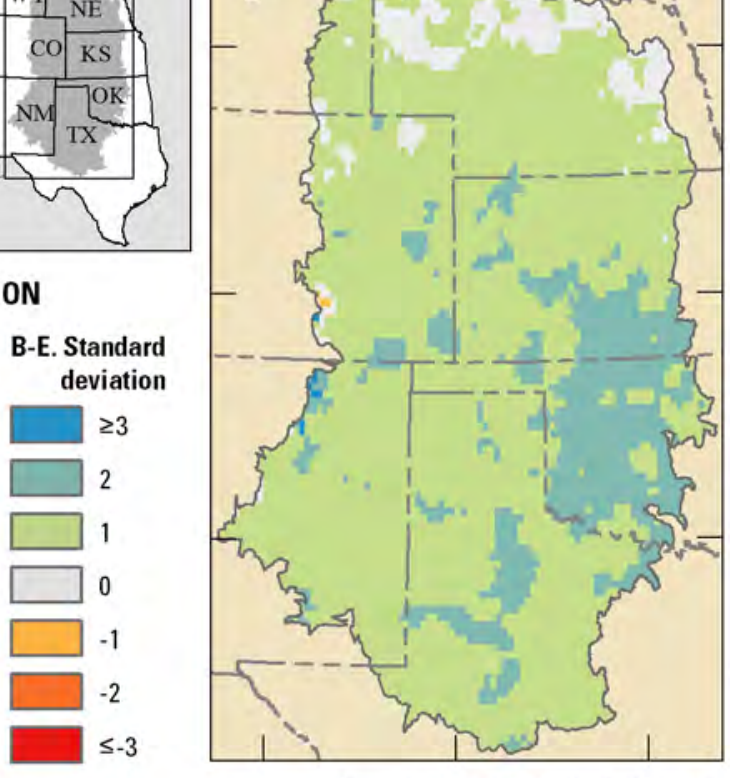

Base map from U.S. Geological Survey, National Map,1:18,883,014 North American Albers Equal Area Conic projection

North American Datum of 1983 , Central Meridian - $102^{\circ}$ W., Standard Parallels $20^{\circ} \mathrm{N}$. and $60^{\circ} \mathrm{W}$.

Figure 7. Difference in the predicted relative productivity of Bouteloua dactyloides (buffalograss), an indicator species for shortgrass prairie, as modeled using four climate scenarios in the Southern Great Plains of the United States. $A$, Contemporary relative productivity of buffalograss. Predicted change in relative productivity of buffalograss for each climate scenario in comparison to contemporary relative productivity for: $B$, warm-wet; $C$, hot-wet; $D$, warm-dry; and $E$, hot-dry conditions. 


\section{Mixed-Grass Prairie}

\section{Sideoats Grama}

Contemporary productivity for sideoats grama was greatest in the southern half of the mixed-grass prairie and across much of the distribution of semi-desert grasslands in the SGP (fig. $8 A$ ). The productivity of sideoats grama was predicted to remain stable throughout the LCD and most of the SGP for all four climate scenarios (fig. $8 B-E$ ). Productivity was predicted to increase in areas outside of the current range of mixed-grass prairie, primarily in areas that were historically tallgrass prairie (fig. 8). These results indicate relatively low sensitivity and adaptive capacity to be moderate for sideoats grama based on the climate scenarios evaluated.

\section{Little Bluestem}

Contemporary productivity for little bluestem was greatest throughout the eastern half of the SGP where little bluestem is most prevalent and was lower in the LCD (fig. 9A). The productivity of little bluestem was predicted to remain stable throughout the northern extent of the current distribution of mixed-grass prairie for all but the warm-dry scenario, in which productivity was predicted to decrease across most of the SGP (fig. $9 B-E$ ). In contrast, productivity was predicted to decrease across much of the southern extent of mixed-grass prairie in all scenarios, except the hot-wet scenario, in which it was predicted to be stable or increase (fig. 9). Because precipitation is the only predictor variable in the little bluestem model, predicted productivity corresponded to the spatial patterning of projected changes in precipitation (fig. 3). Collectively, the models predicted the greatest productivity levels for this species across the eastern side of the SGP where mixed- and tallgrass prairie are most prevalent (figs. 1-6). Depending on precipitation changes, these results indicate moderate sensitivity and relatively limited adaptability of little bluestem to the climate scenarios evaluated, primarily in the southern portions of mixed-grass prairie.

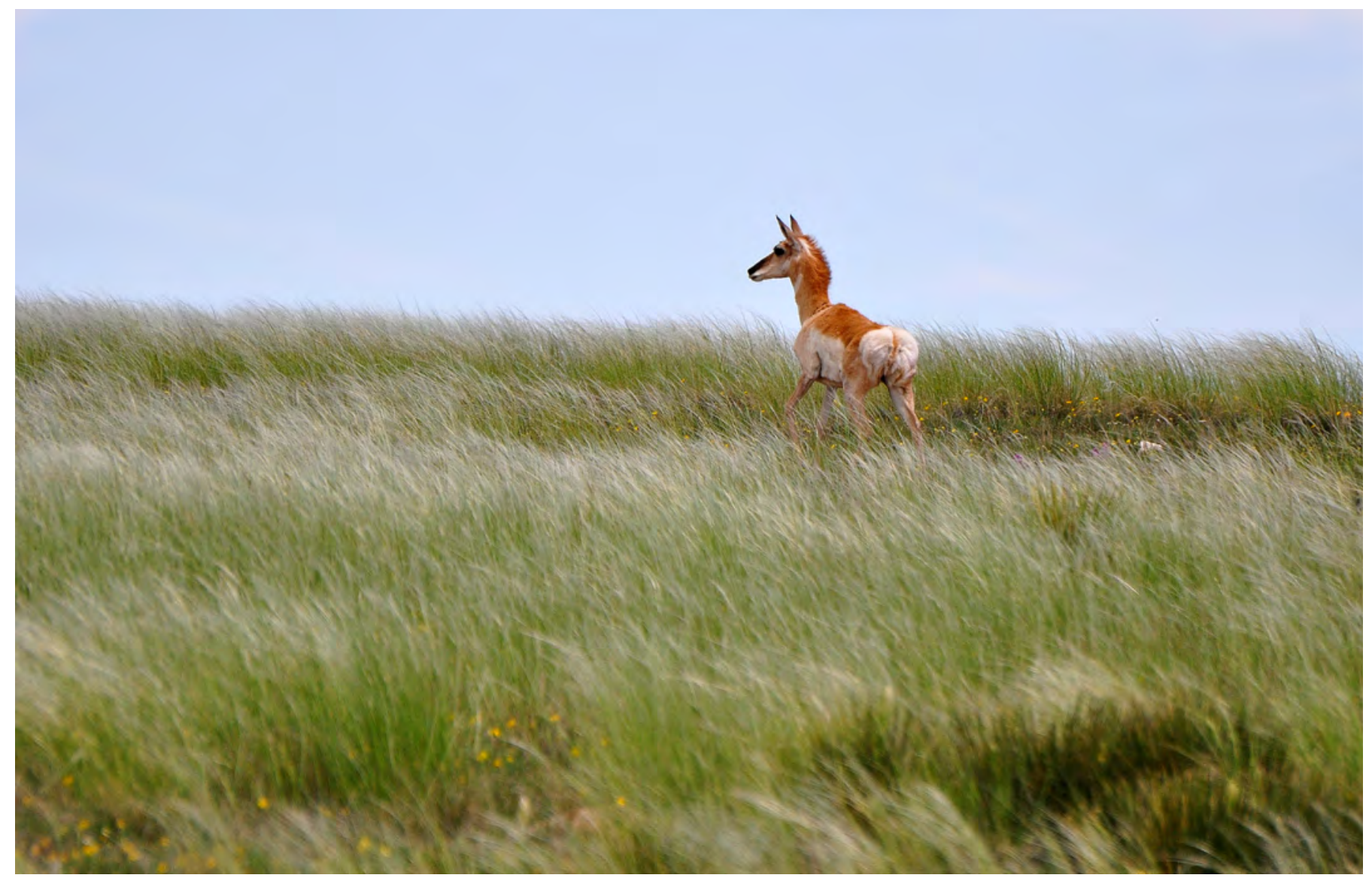

An Antilocapra americana (pronghorn) in Kiowa National Grasslands, New Mexico. The grasslands are an example of a mixed-grass prairie. Photograph by Larry Lamsa, May 29, 2010. 

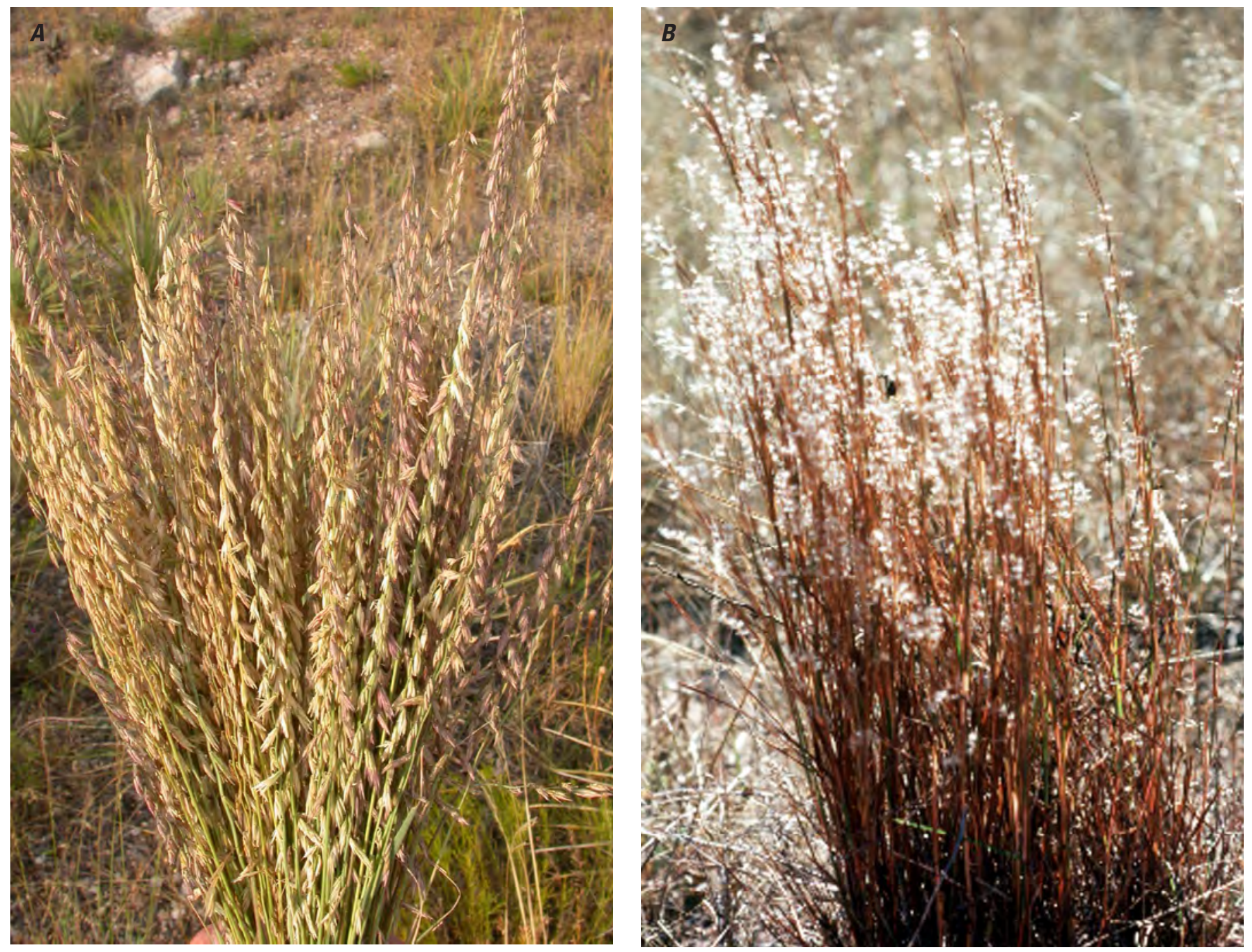

A, Bouteloua curtipendula (sideoats grama). The inflorescence of sideoats gramma comprises many short lateral branches that bear several spikelets on one side (in a secund arraignment). Photograph by Matt Lavin, Flickr, July 29, 2009. Accessed June 11, 2019. B, Schizachyrium scoparium (little bluestem), southern wetland flora. Photograph by L. Glasscock, 1991. Hosted by the U.S. Department of Agriculture, Natural Resources Conservation Service (NRCS), PLANTS database. Productivity suitable for one or both indicator species for mixed-grass prairie was predicted to be stable or increase for wet climate scenarios and stable or decrease for dry climate scenarios evaluated. 

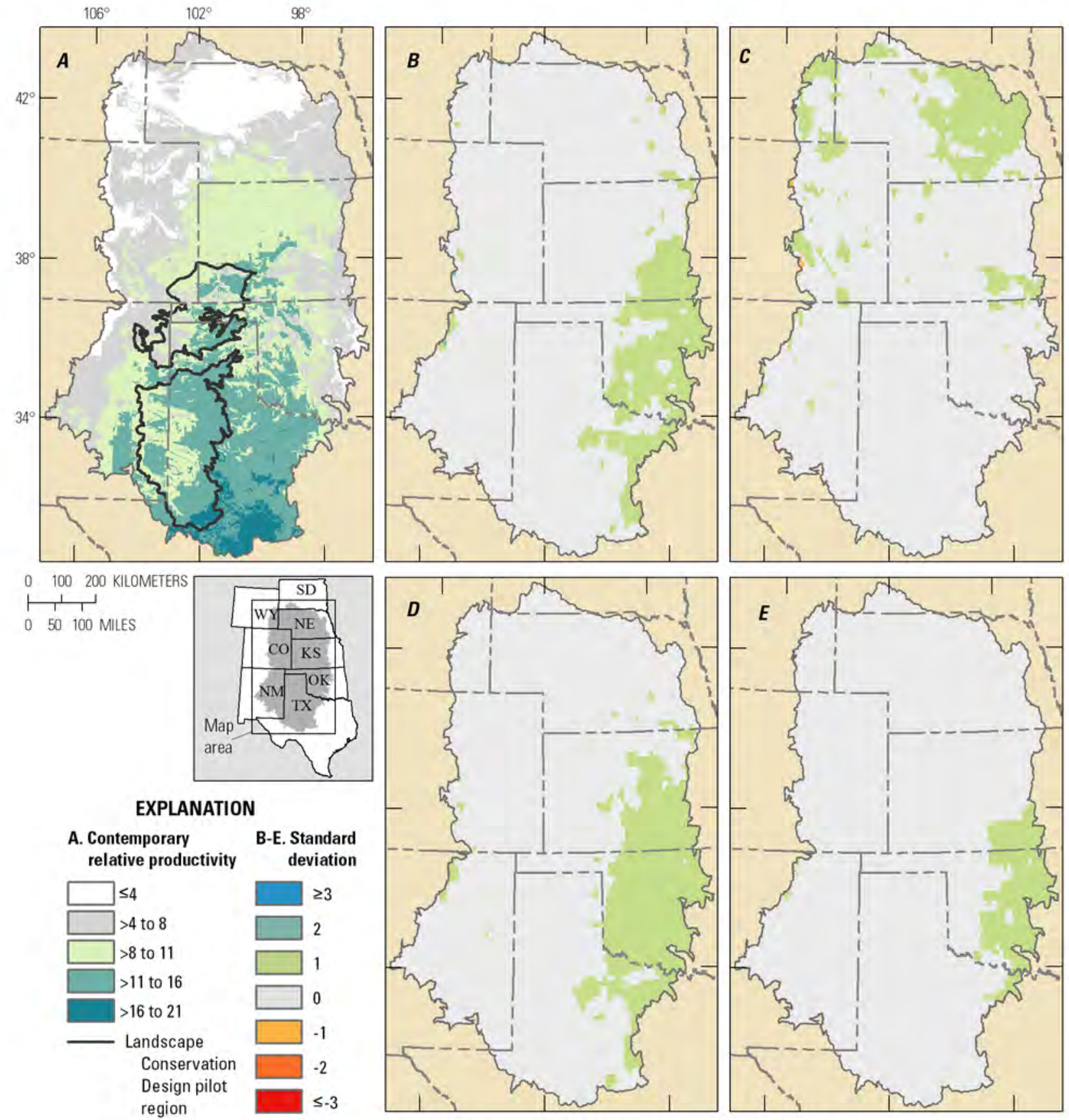

Base map from U.S. Geological Survey, National Map,1:18,883,014

North American Albers Equal Area Conic projection

North American Datum of 1983 , Central Meridian $-102^{\circ}$ W., Standard Parallels $20^{\circ} \mathrm{N}$. and $60^{\circ} \mathrm{W}$.

Figure 8. Difference in the predicted relative productivity of Bouteloua curtipendula (sideoats grama), an indicator species for mixedgrass prairie, as modeled using four climate scenarios in the Southern Great Plains of the United States. $A$, Contemporary relative productivity of sideoats grama. Predicted change in relative productivity of sideoats grama for each climate scenario in comparison to contemporary relative productivity for: $B$, warm-wet; $C$, hot-wet; $D$, warm-dry; and $E$, hot-dry conditions. 

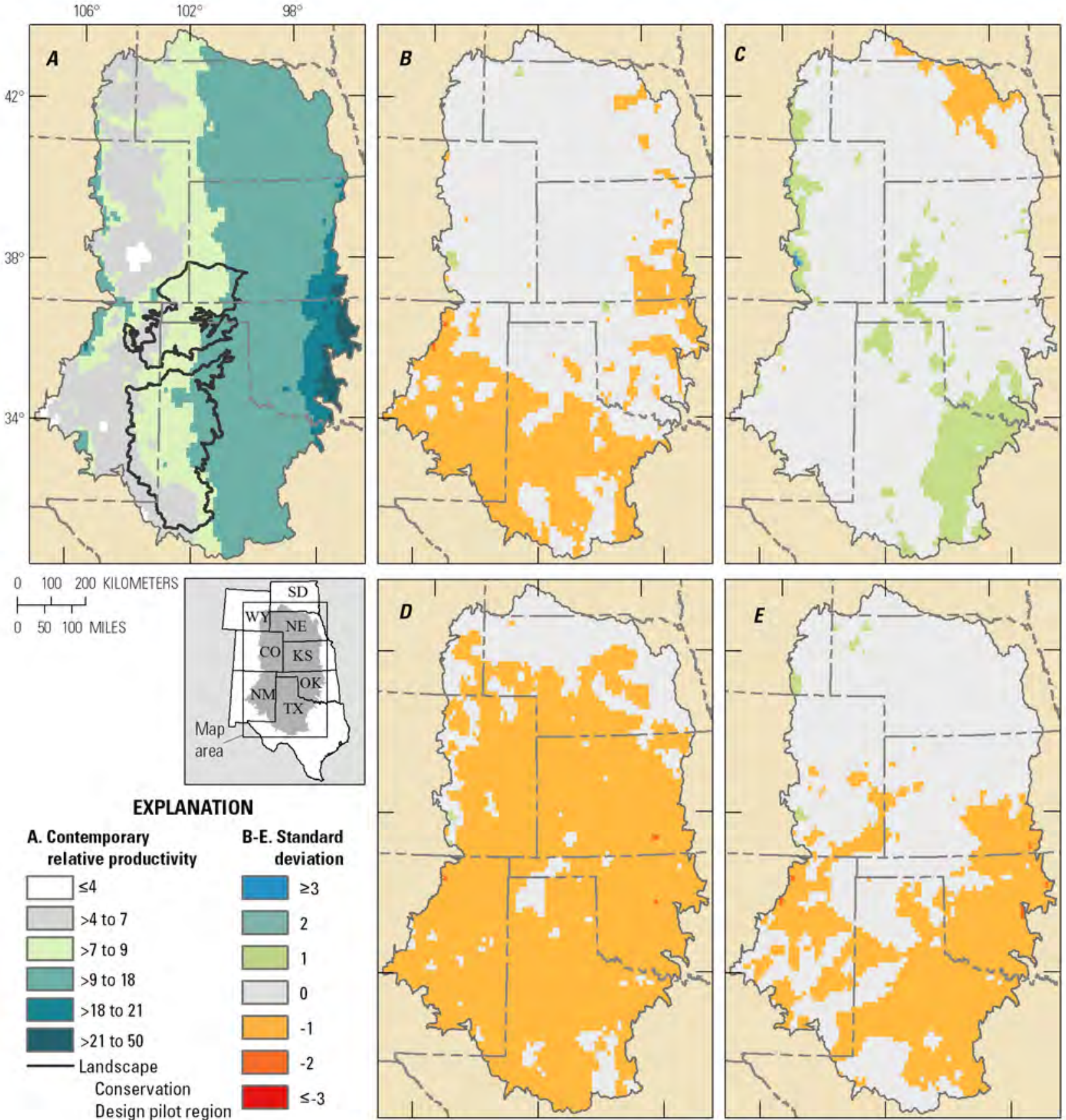

\begin{tabular}{|c|c|}
\hline $\begin{array}{l}\text { A. Contemporary } \\
\text { relative productivity }\end{array}$ & \\
\hline$\leq 4$ & \\
\hline$>4$ to 7 & \\
\hline$>7$ to 9 & \\
\hline$>9$ to 18 & \\
\hline$>18$ to 21 & \\
\hline$>21$ to 50 & \\
\hline Landscape & \\
\hline $\begin{array}{l}\text { Conservation } \\
\text { Design pilot region }\end{array}$ & \\
\hline
\end{tabular}

Base map from U.S. Geological Survey, National Map,1:18,883,014

North American Albers Equal Area Conic projection

North American Datum of 1983 , Central Meridian - $102^{\circ}$ W., Standard Parallels $20^{\circ} \mathrm{N}$. and $60^{\circ} \mathrm{W}$.

Figure 9. Difference in the predicted relative productivity of Schizachyrium scoparium, little bluestem, an indicator species for mixedgrass prairie, as modeled using four climate scenarios in the Southern Great Plains of the United States. A, Contemporary relative productivity of little bluestem. Predicted change in relative productivity of little bluestem for each climate scenario in comparison to contemporary relative productivity for: $B$, warm-wet; $C$, hot-wet; $D$, warm-dry; and $E$, hot-dry conditions. 


\section{Tallgrass Prairie}

\section{Indiangrass}

Contemporary productivity for Indiangrass was greatest along the eastern margins of the SGP, corresponding to the western extent of the tallgrass prairie, and was very low across the LCD (fig. 10A). Productivity was predicted to decrease across the entire distribution of tallgrass prairie in the SGP for both of the dry scenarios (fig. $10 D$ and $E$ ) and the warm-wet scenario (fig. 10B). Only the hot-wet scenario (fig. 10C) exhibited potential for mostly stable or increasing productivity. Because temperature is not included as a predictor variable in the Indiangrass model, predicted productivity corresponded primarily to the spatial patterning of projected changes in precipitation (fig. 3). Results for Indiangrass indicated high sensitivity and low adaptive capacity to all but the hot-wet climate scenario.

\section{Big Bluestem}

Contemporary productivity for big bluestem was greatest along the eastern edge of the SGP within the western extent of the tallgrass prairie and was very low in the LCD (fig. 11A4H). Productivity was predicted to decrease or remain stable across much of the tallgrass prairie for all scenarios (fig. 11). Productivity was predicted to decline across the entire current distribution of tallgrass prairie for both of the dry scenarios (fig. $12 D$ and $E$ ). Declines were less extreme for the wet scenarios, indicating that increasing precipitation could ameliorate the vulnerability of big bluestem to rising temperatures (fig. $11 B$ and $C$ ). Results for big bluestem indicated relatively high sensitivity and low adaptive capacity to all four climate scenarios evaluated.

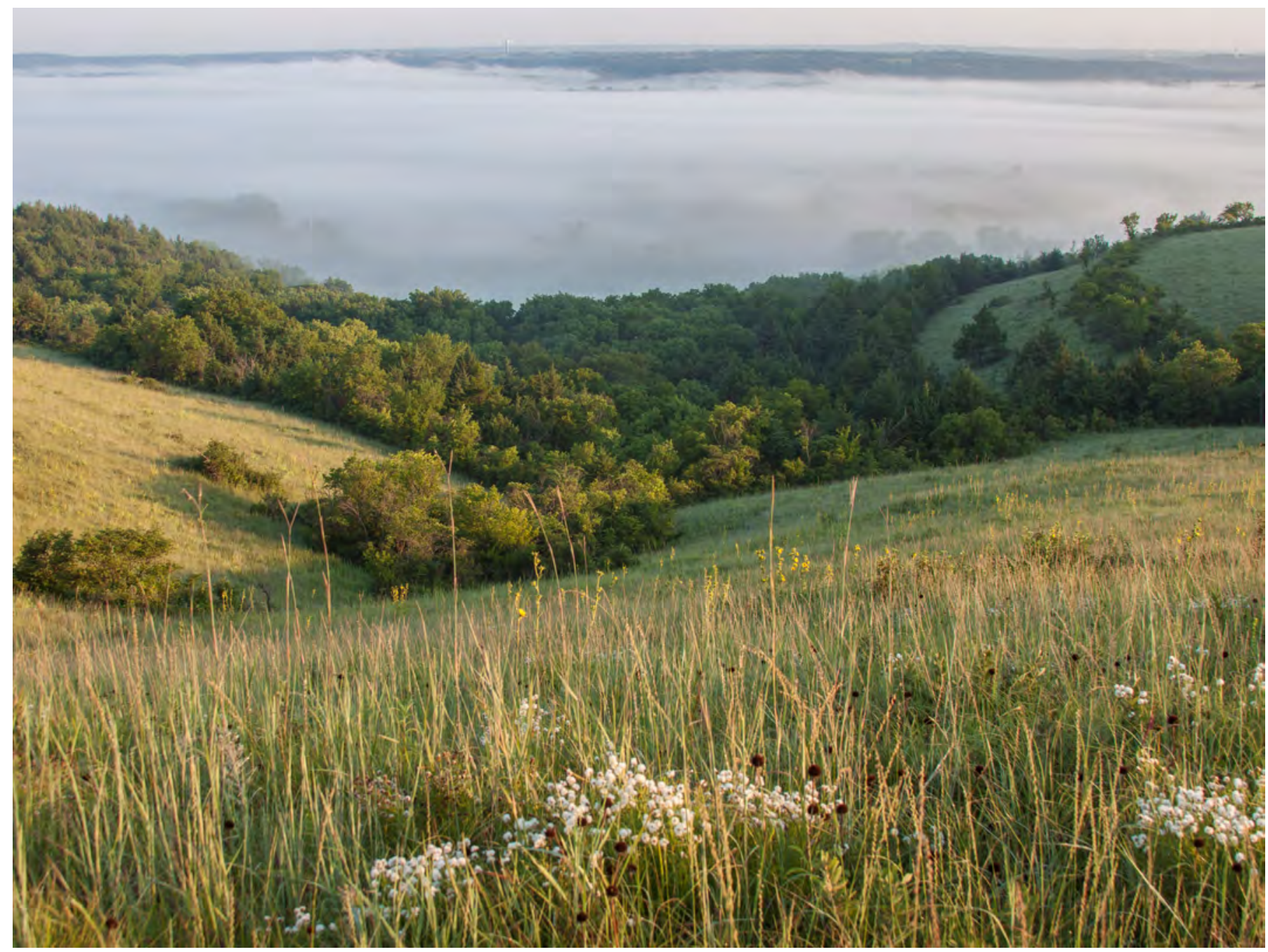



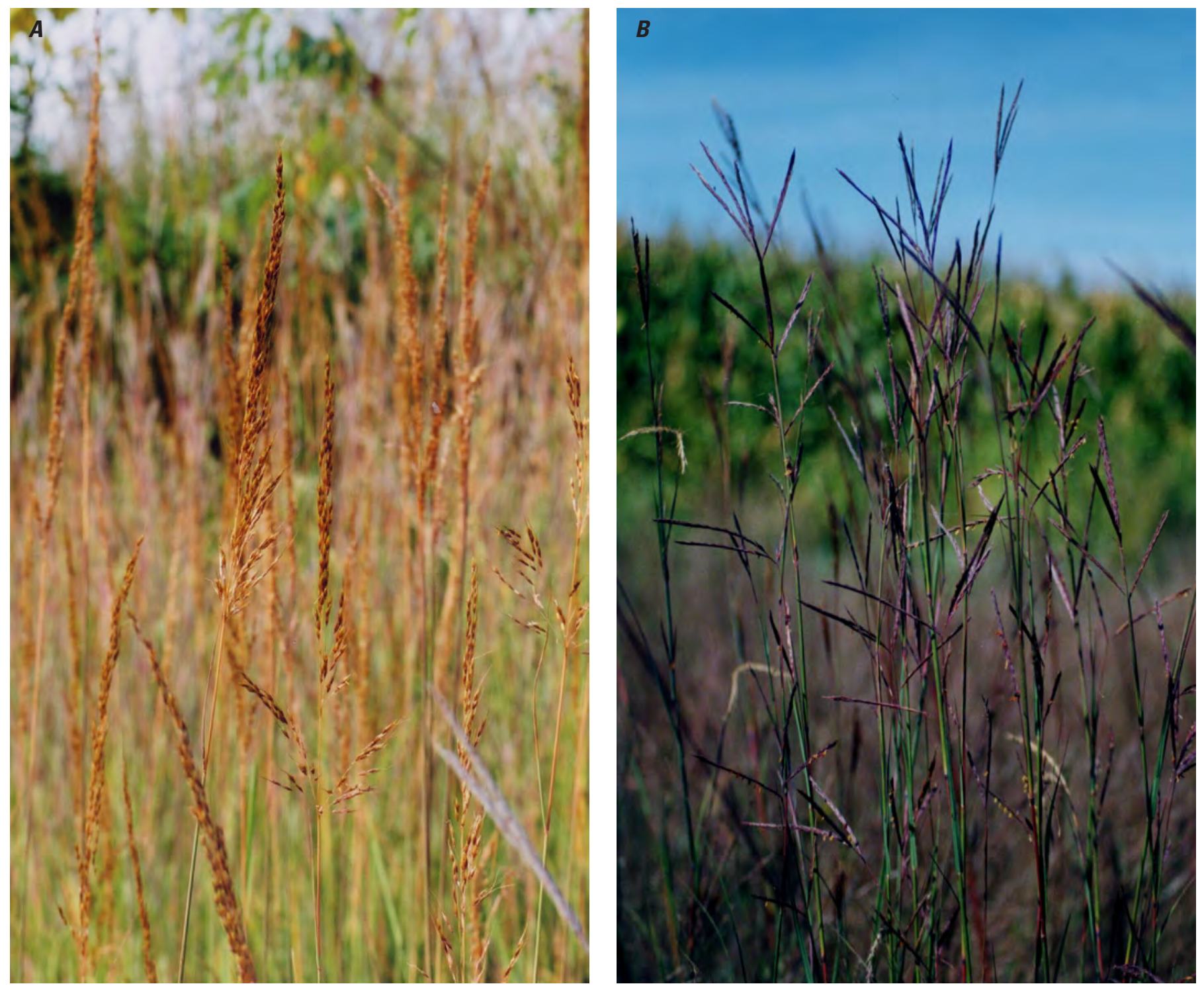

A, Sorghastrum nutans (Indiangrass) in Pigeon Creek Park, lowa. Photograph by Jennifer Anderson, 2002. Hosted by the U.S. Department of Agriculture, Natural Resources Conservation Service (NRCS), PLANTS database, March 11, 2019. B, Andropogon gerardii (big bluestem) in Pigeon Creek Park, lowa. Photograph by Jennifer Anderson, 2002. Hosted by the U.S. Department of Agriculture, Natural Resources Conservation Service (NRCS), PLANTS database. Productivity suitable for both indicator species for tallgrass prairie was predicted to decrease for all climate scenarios evaluated. 

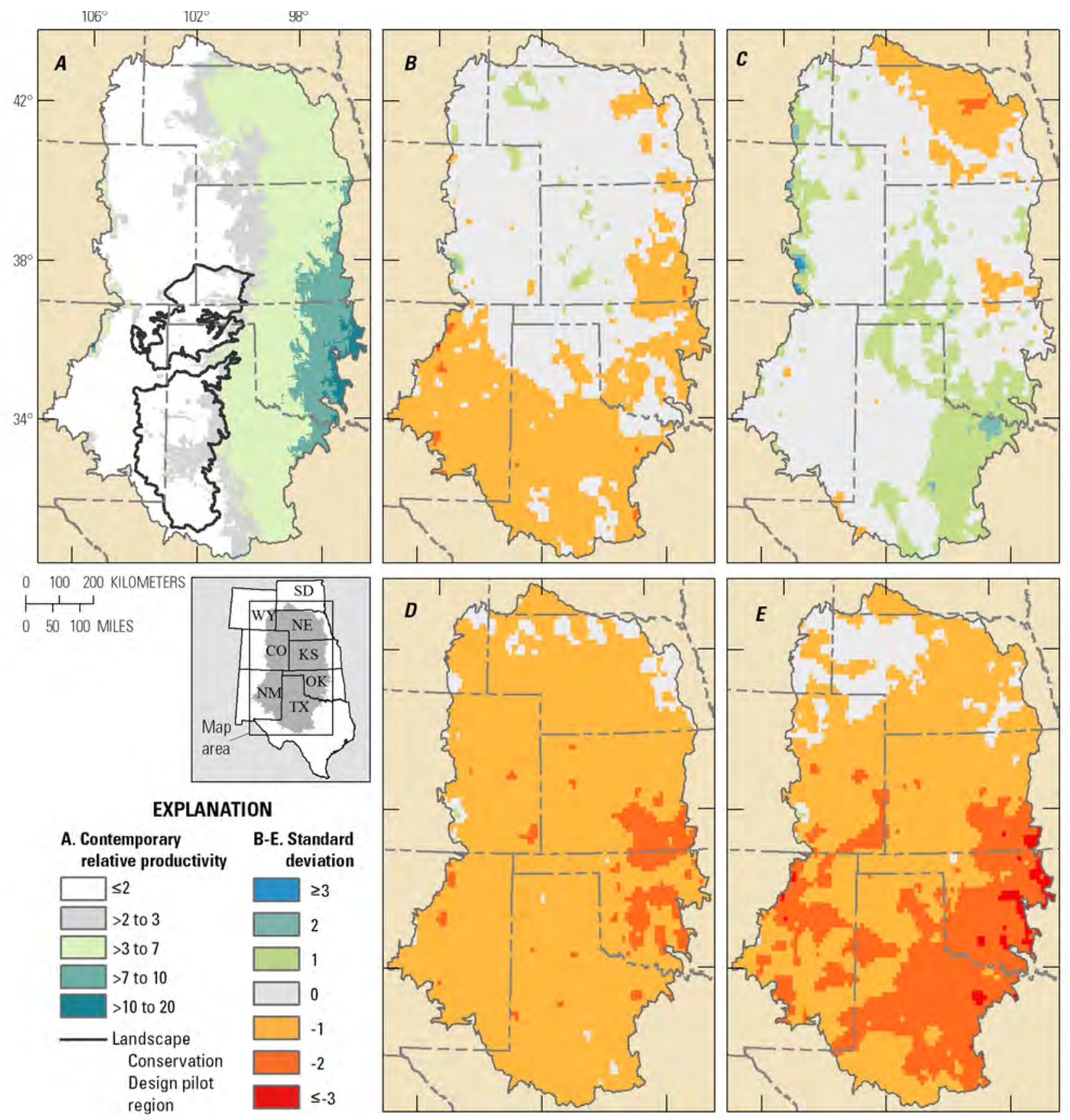

Base map from U.S. Geological Survey, National Map,1:18,883,014

North American Albers Equal Area Conic projection

North American Datum of 1983 , Central Meridian $-102^{\circ}$ W., Standard Parallels $20^{\circ} \mathrm{N}$. and $60^{\circ} \mathrm{W}$.

Figure 10. Difference in the predicted relative productivity of Sorghastrum nutans (Indiangrass), an indicator species for tallgrass prairie, as modeled using four climate scenarios in the Southern Great Plains of the United States. A, Contemporary relative productivity of Indiangrass. Predicted change in relative productivity of Indiangrass for each climate scenario in comparison to contemporary relative productivity for: $B$, warm-wet; $C$, hot-wet; $D$, warm-dry; and $E$, hot-dry conditions. 

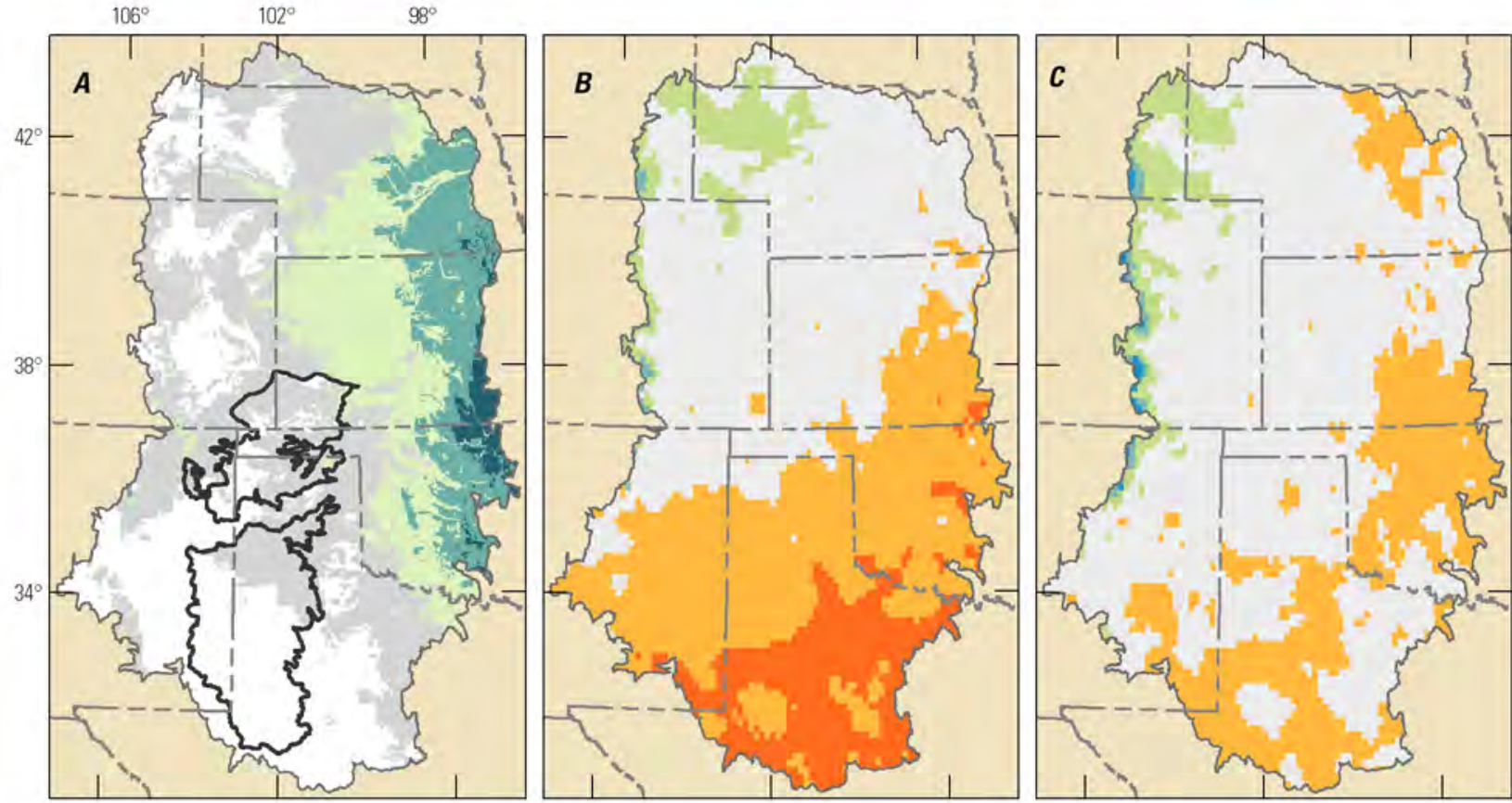

$\overbrace{0}^{0} \underbrace{0}_{0} 100 \quad 200$ KILON
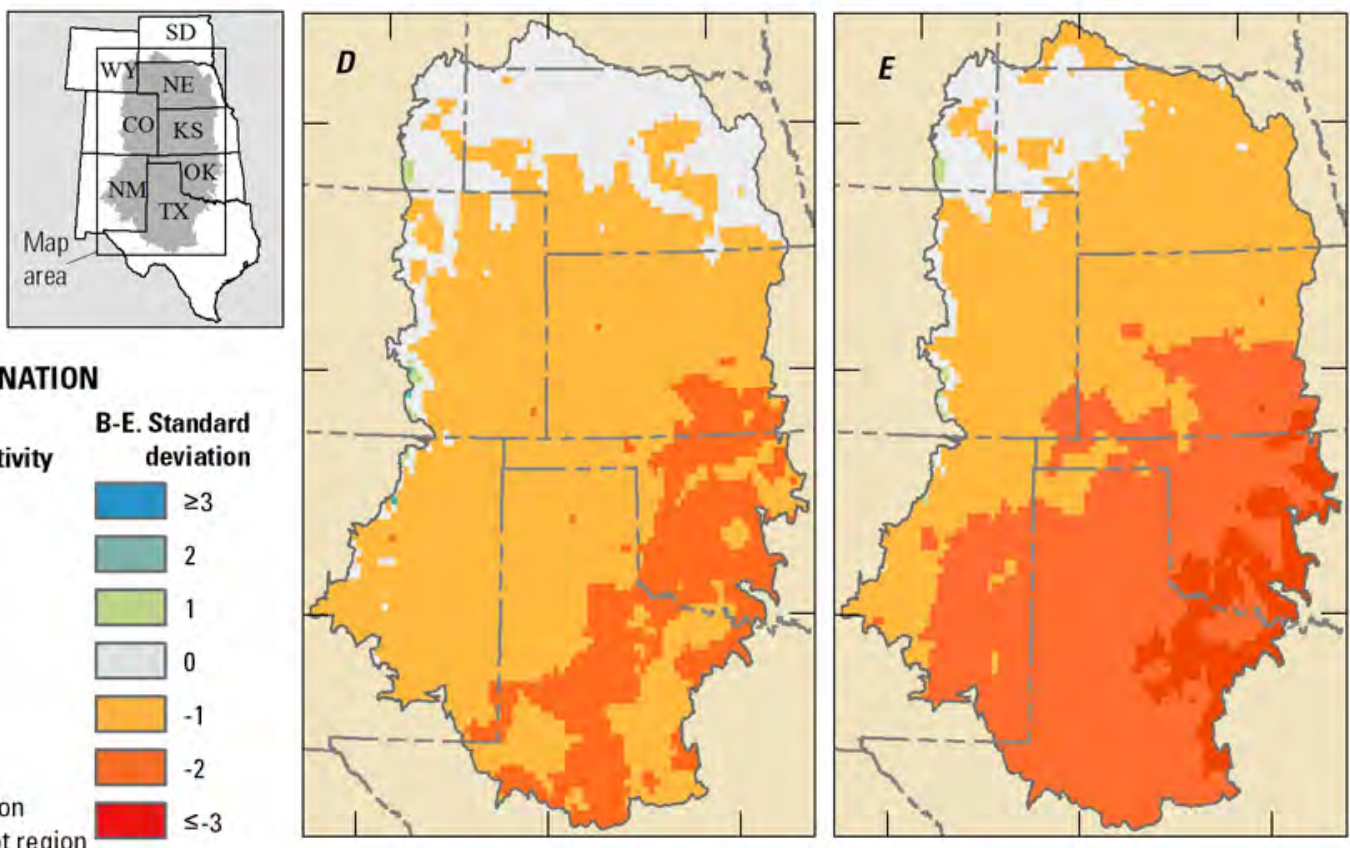

Base map from U.S. Geological Survey, National Map,1:18,883,014

North American Albers Equal Area Conic projection

North American Datum of 1983 , Central Meridian $-102^{\circ}$ W., Standard Parallels $20^{\circ} \mathrm{N}$. and $60^{\circ} \mathrm{W}$.

Figure 11. Difference in the predicted relative productivity of Andropogon gerardii (big bluestem), an indicator species for tallgrass prairie, as modeled using four climate scenarios in the Southern Great Plains of the United States. $A$, Contemporary relative productivity of big bluestem. Predicted change in relative productivity of big bluestem for each climate scenario in comparison to contemporary relative productivity for: $B$, warm-wet; $C$, hot-wet; $D$, warm-dry; and $E$, hot-dry conditions. 


\section{Community-Level Vulnerability to Climate Scenarios}

To evaluate the potential for community-level changes, the spatial concurrence of predicted changes in productivity for both indicator species were evaluated relative to the current distribution of the associated grassland community. Only the hot scenarios were presented as maps (figs. 12-15), because they represent the largest projected changes in temperature and precipitation evaluated (table 2) and therefore provide an indication of areas with the greatest potential vulnerability. Community-level summaries for each climate scenario are summarized in figure 16. Both semi-desert grassland species were predicted to increase in productivity across the current range of this community for all climate scenarios (figs. 12 and 16A). One or both shortgrass prairie species were predicted to increase in productivity across the current range of this community for all scenarios (fig 16B), but the predicted changes for these indicator species were less consistent for the hot-wet scenario especially in southern portions of the current distribution of shortgrass prairie (fig. 13). Both mixed-grass species were predicted to have stable or decreasing productivity for dry scenarios (figs. $14 \mathrm{~A}$ and $16 \mathrm{C}$ ), whereas productivity was predicted to be more stable and increasing in some places for wet scenarios (figs. $14 B$ and 16C). Productivity for both tallgrass species was predicted to exhibit widespread decreases for all scenarios, although the spatial patterns were more mixed for the hot-wet scenario (figs. 15 and 16D). These results reflect the gradient in potential sensitivities and adaptive capacity of these species to increasing temperature and decreasing precipitation among the communities; semi-desert grasslands were predicted to be the least vulnerable and tallgrass prairie the most vulnerable to the climate scenarios evaluated (fig. 16).

\section{Relative and Synergistic Effects of Land Use and Climate Change}

Land use in the SGP has the potential to reduce the capacity of grassland communities to adapt to changing climates. Conversion and fragmentation of grasslands by development vary spatially and by community type (figs. $1 B$ and 17 ). Overall, the lowest levels of development (terrestrial development index [TDI] scores $\leq 5$ ) represents 33 percent of the SGP (fig. 17), but 19 percent of the LCD. Grasslands with the least development are largely restricted to the western and northern portions of the SGP. TDI scores $\leq 5$ represents 75 percent of semi-desert grasslands and 56 percent of shortgrass prairie, whereas it represents 24 percent of mixed-grass prairie and 12 percent of tallgrass prairie. Comparison of these development patterns with the results from the climate scenarios indicates that the species projected to have stable or increased productivity (tobosagrass, black grama, blue grama and buffalograss) are dominant in the communities with the lowest fragmentation from current development, indicating relatively low vulnerability to the climate scenarios evaluated. In contrast, conversion and fragmentation are greatest in the grassland communities occupied by the taller grass species (sideoats grama, little bluestem, Indiangrass and big bluestem), which were also predicted to be most vulnerable to projected climate change, indicating the greater vulnerability of these communities.

\section{Discussion}

Scenario planning is a useful tool for identifying key vulnerabilities of ecological systems to changing climates, informed by the potential outcomes of a set of divergent, plausible, and relevant climate scenarios (National Park Service, 2013; Symstad and others, 2017a, b). One goal of scenario planning is to recognize potential risks and identify opportunities for management despite uncertainty about future conditions or the limitations imposed by constraints, such as changing land-use patterns or feasible management options. The climate scenarios and associated modeled responses do not predict the likelihood of any particular ecological future, but rather represent a set of possible outcomes from an indeterminate set of plausible futures. By evaluating critical, but highly uncertain, drivers of grassland composition and dynamics, scenario planning can be useful for evaluating the robustness of planning and management actions for a diverse set of possible futures in the Southern Great Plains.

The results presented here suggest that current land use patterns, in conjunction with a range of plausible climate projections, create greater vulnerability of mixed-grass and tallgrass prairies of the SGP compared to semi-desert grasslands and shortgrass prairie. For most climate scenarios evaluated, bioclimatic conditions conducive to the taller species (little bluestem, Indiangrass, and big bluestem) were predicted to contract within some or all of the current distribution of mixed-grass and tallgrass prairies within the SGP. An increase in precipitation, however, could potentially offset the negative effects of increasing temperatures as evidenced by higher productivity for the hot-wet scenario compared to the other scenarios. Importantly, the models (Epstein and others, 1998) did not include evapotranspiration as a model predictor, and the interactive effects of temperature and atmospheric conditions with soil moisture budgets could affect availability of water for plants (Chapin and others, 2002). Thus, increased temperatures and other 


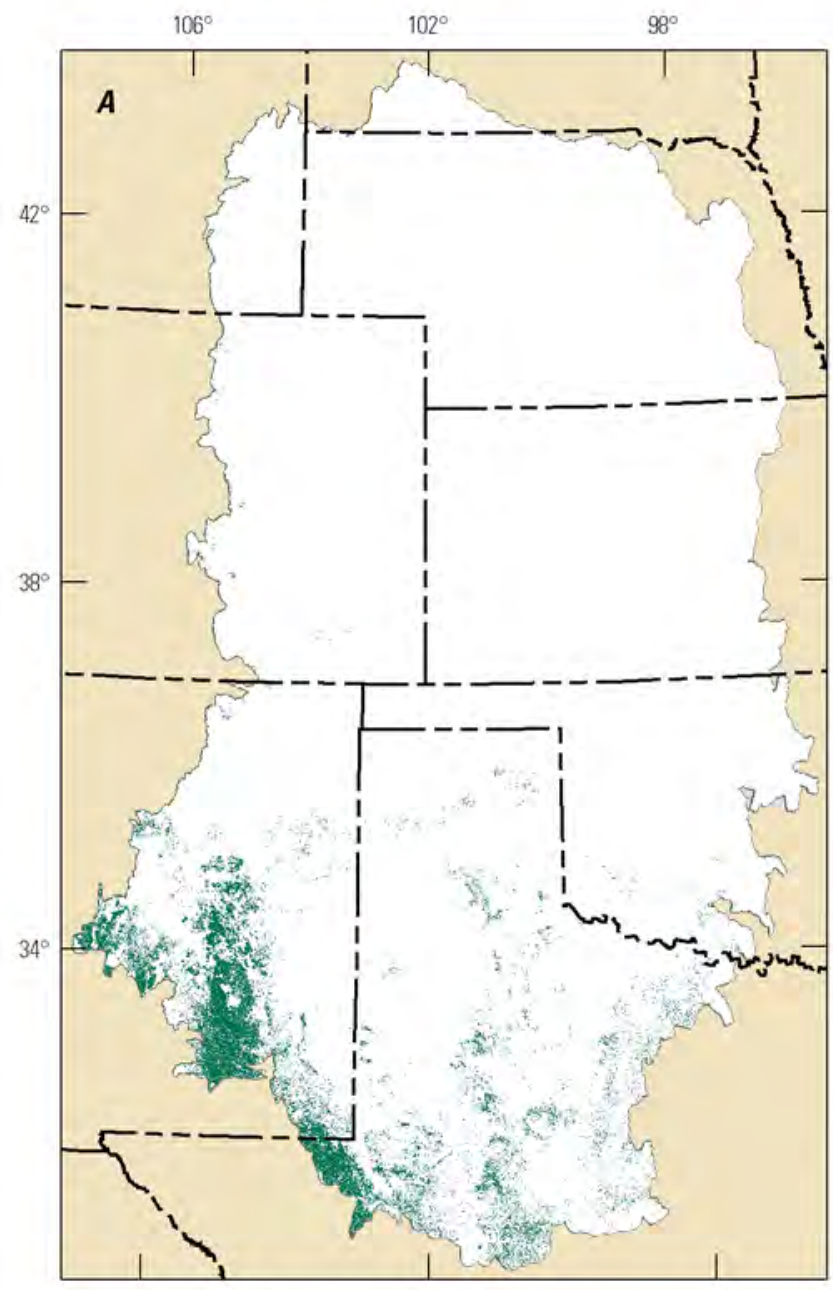

$0 \quad 100 \quad 200$ KILOMETERS
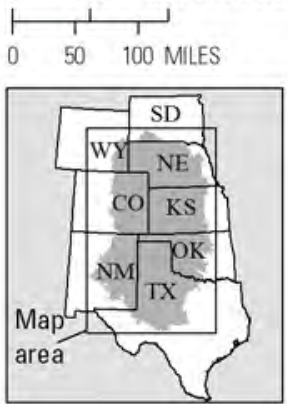

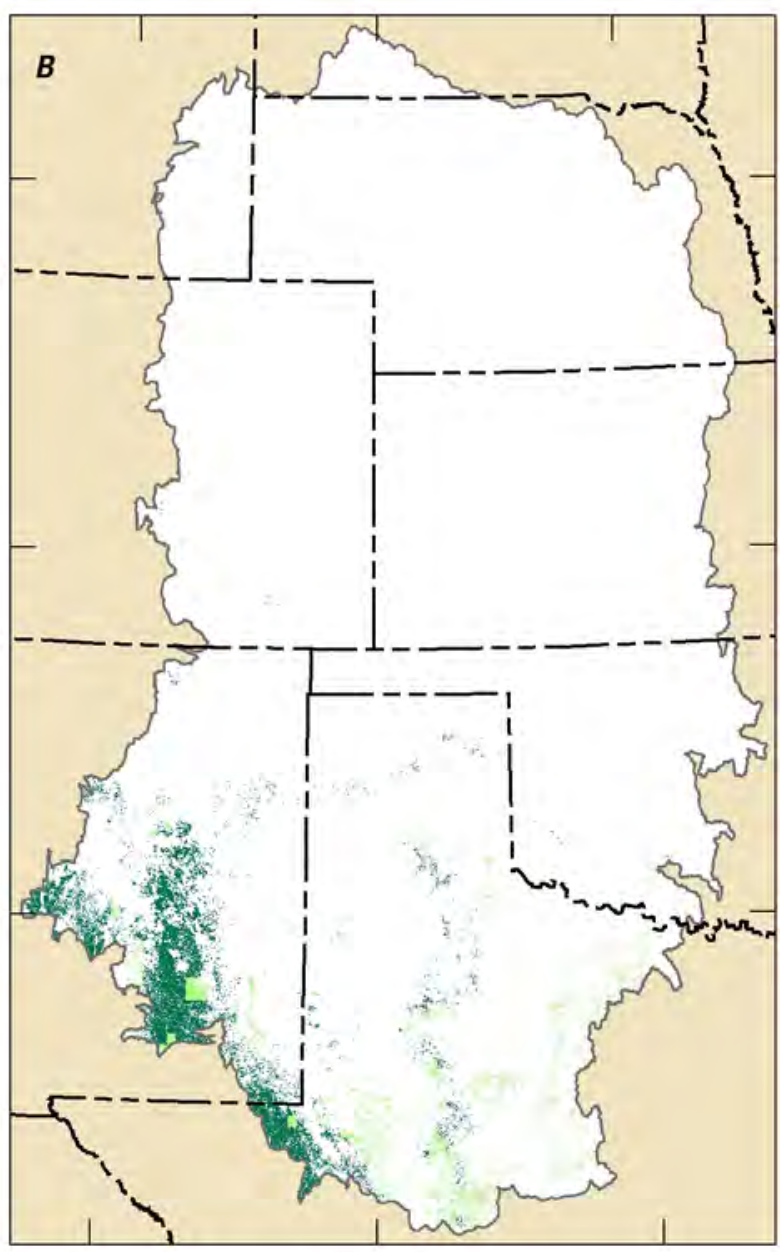

Base map from U.S. Geological Survey National Map,1:12,635,439

North American Albers Equal Area Conic projection North American Datum of 1983

Central Meridian $-102^{\circ} \mathrm{W}$.

Standard Parallels $20^{\circ} \mathrm{N}$. and $60^{\circ} \mathrm{W}$.

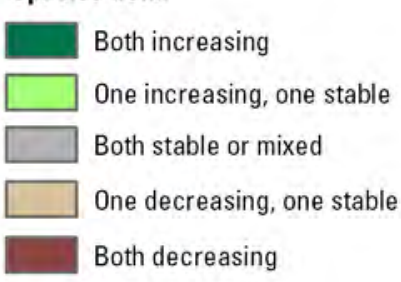

Figure 12. Predicted changes in productivity for Pleuraphis mutica (tobosagrass) and Bouteloua eriopoda (black grama) within the current distribution of semi-desert grasslands in the Southern Great Plains of the United States for $A$, hot-dry; and $B$, hot-wet climate scenarios. Areas without color (white) are outside the current distribution of semi-desert grasslands. 


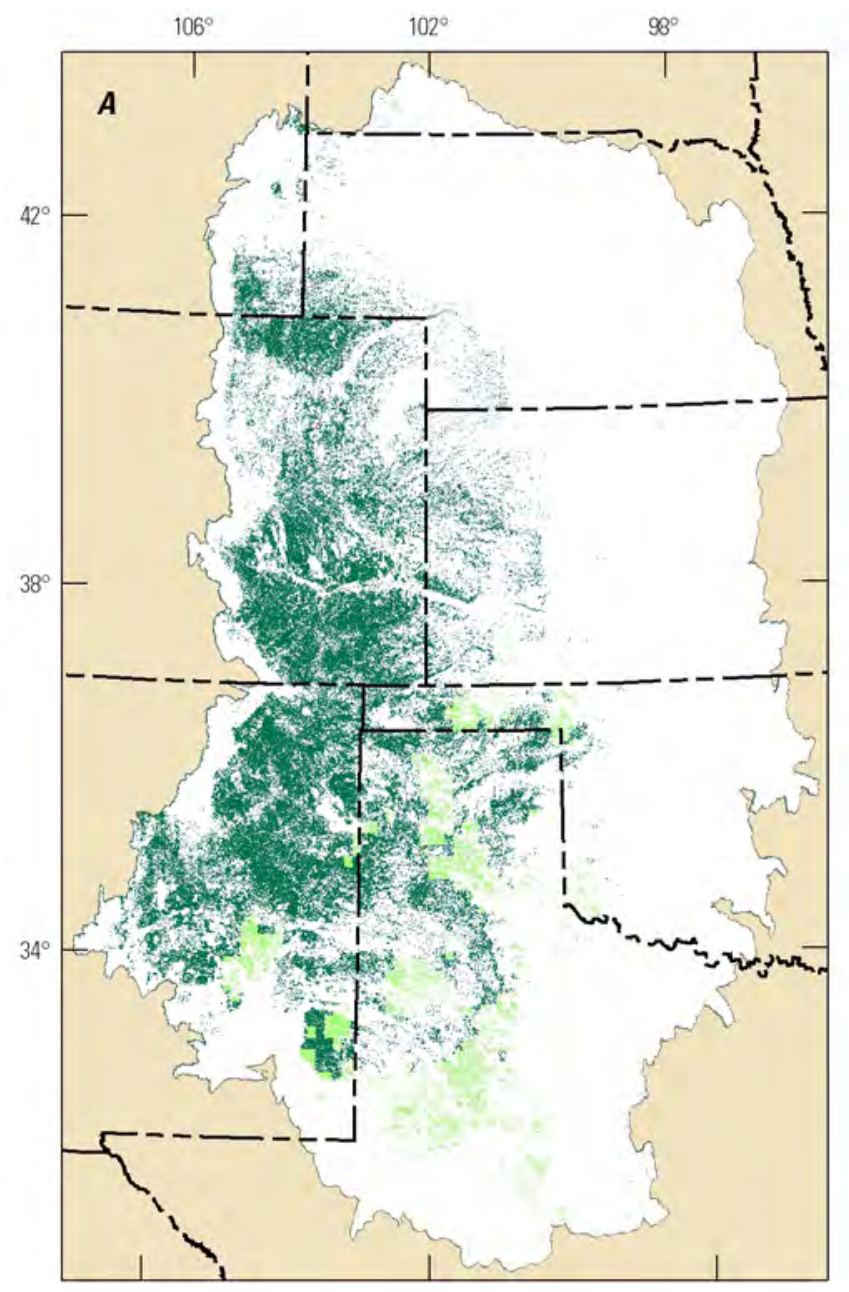

0 $100 \quad 200$ KILOMETERS
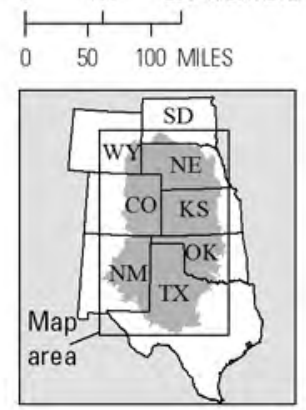

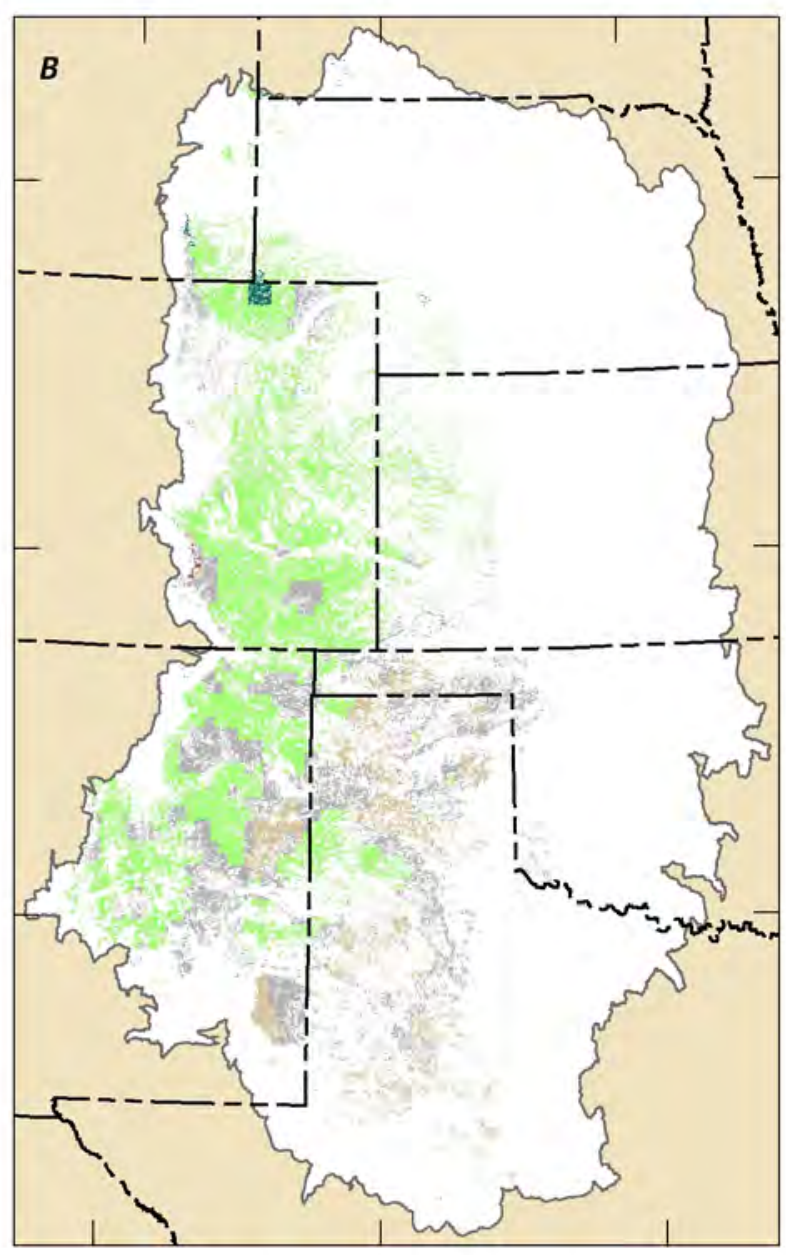

Base map from U.S. Geological Survey National Map, 1:12,635,439

North American Albers Equal Area Conic projection North American Datum of 1983

Central Meridian $-102^{\circ} \mathrm{W}$.

Standard Parallels $20^{\circ} \mathrm{N}$. and $60^{\circ} \mathrm{W}$.
Both increasing

One increasing, one stable

Both stable or mixed

One decreasing, one stable

Both decreasing

Figure 13. Predicted changes in productivity for Bouteloua gracilis (blue grama) and Bouteloua dactyloides (buffalograss) within the current distribution of shortgrass prairie in the Southern Great Plains of the United States for $A$, hot-dry; and $B$, hot-wet climate scenarios. Areas without color (white) are outside the current distribution of shortgrass prairies. 


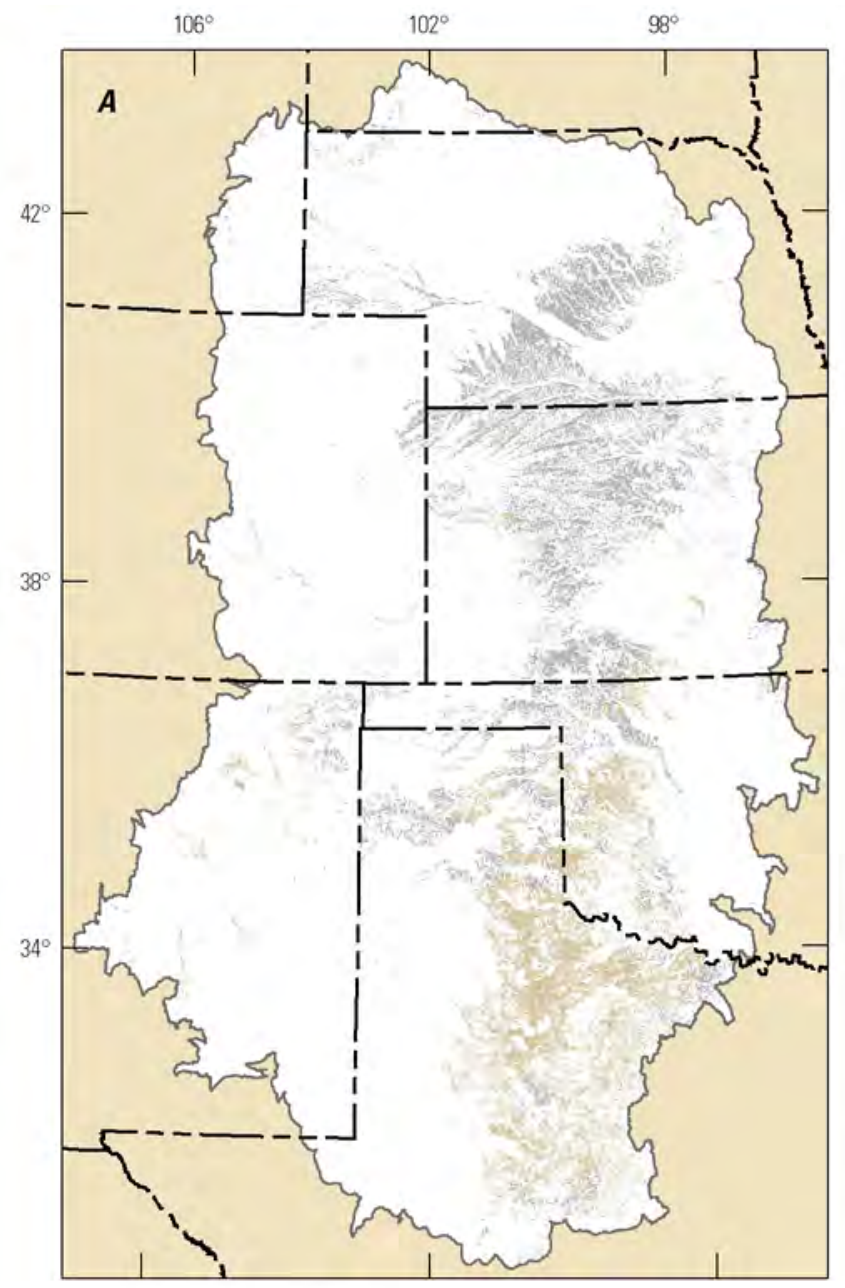

$0 \quad 100 \quad 200$ KILOMETERS
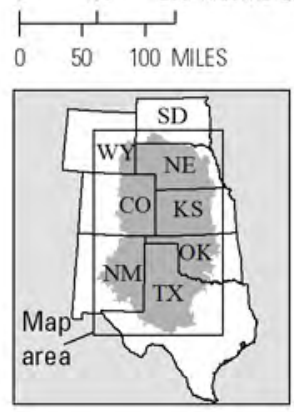

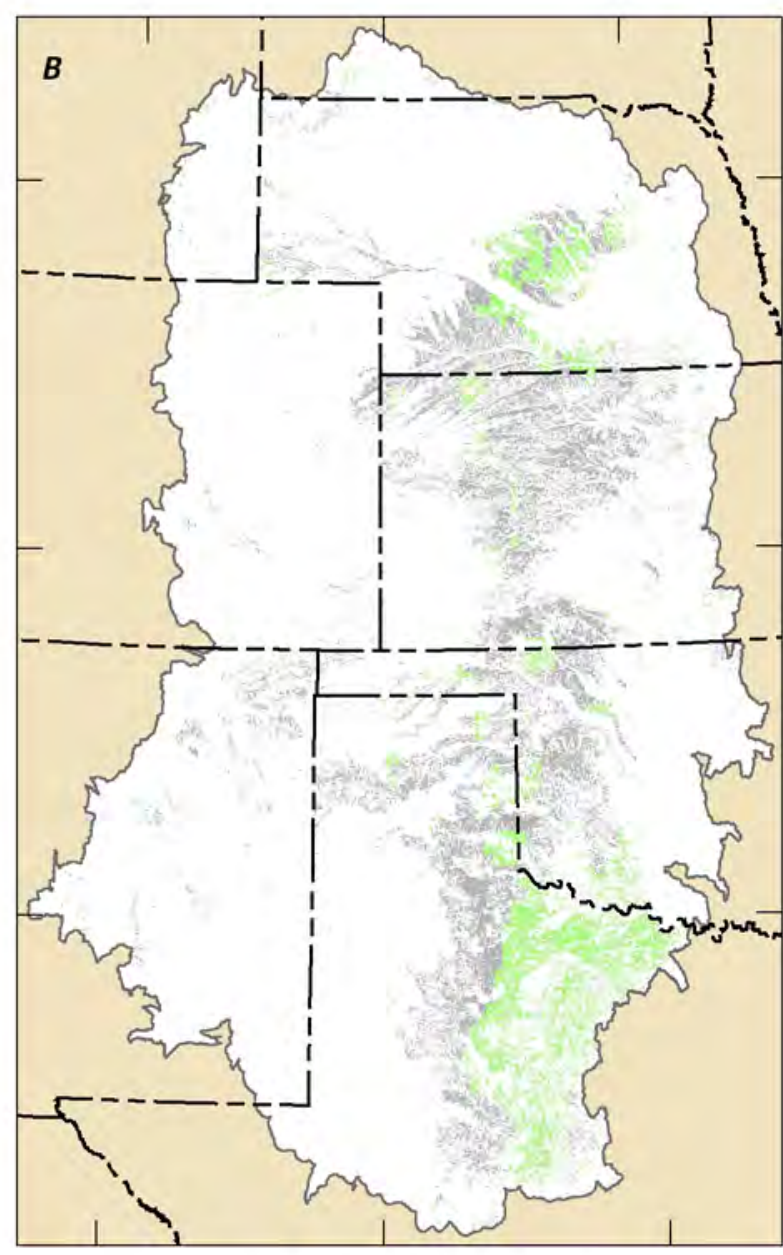

Base map from U.S. Geological Survey National Map,1:12,635,439

North American Albers Equal Area Conic projection North American Datum of 1983

Central Meridian $-102^{\circ} \mathrm{W}$.

Standard Parallels $20^{\circ} \mathrm{N}$. and $60^{\circ} \mathrm{W}$.
Species trend
Both increasing

One increasing, one stable

Both stable or mixed

One decreasing, one stable

Both decreasing

Figure 14. Predicted changes in productivity for Bouteloua curtipendula (sideoats grama) and Schizachyrium scoparium (little bluestem) within the current distribution of mixed-grass prairie in the Southern Great Plains of the United States for $A$, hot-dry; and $B$, hot-wet climate scenarios. Areas without color (white) are outside the current distribution of mixed-grass prairie. 


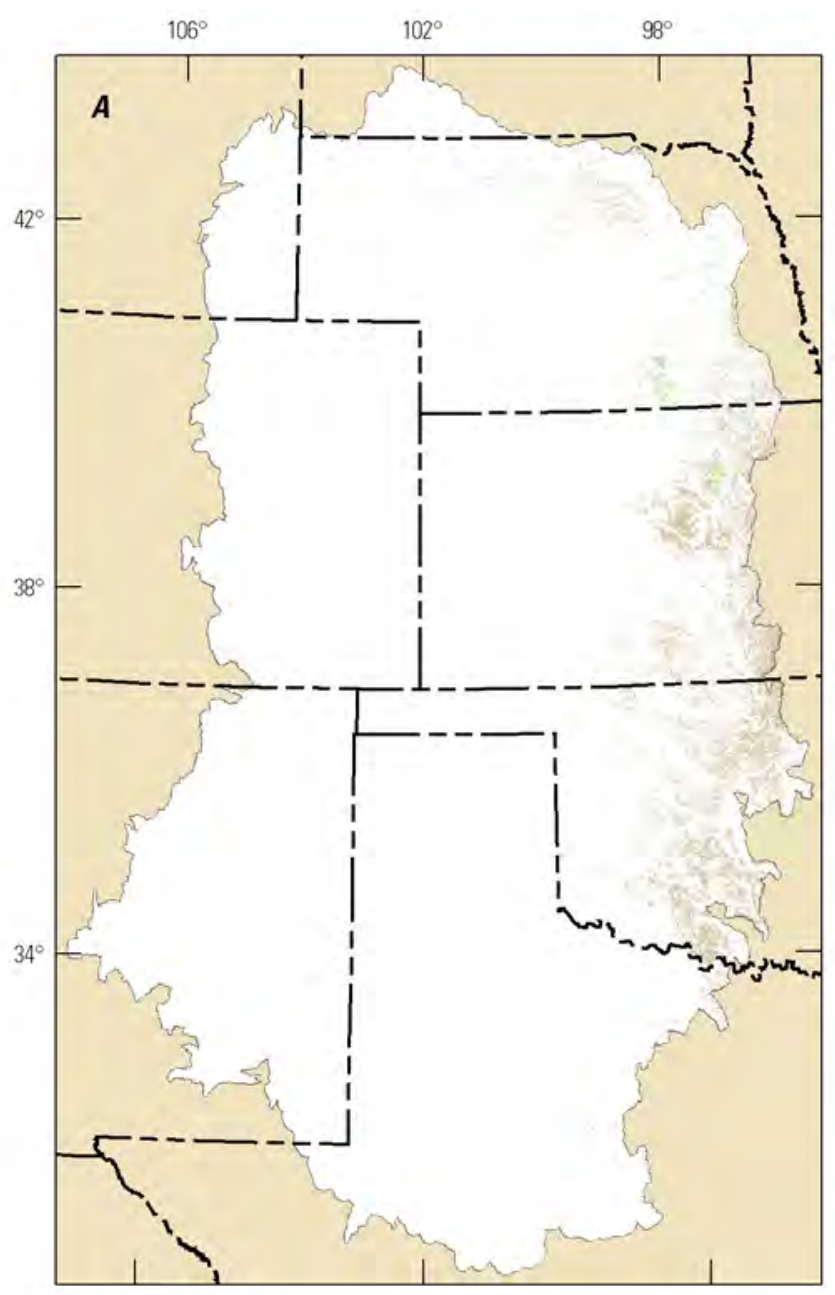

$0 \quad 100 \quad 200$ KILOMETERS
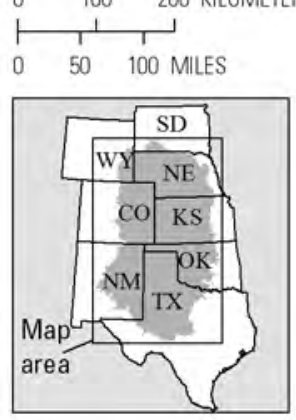

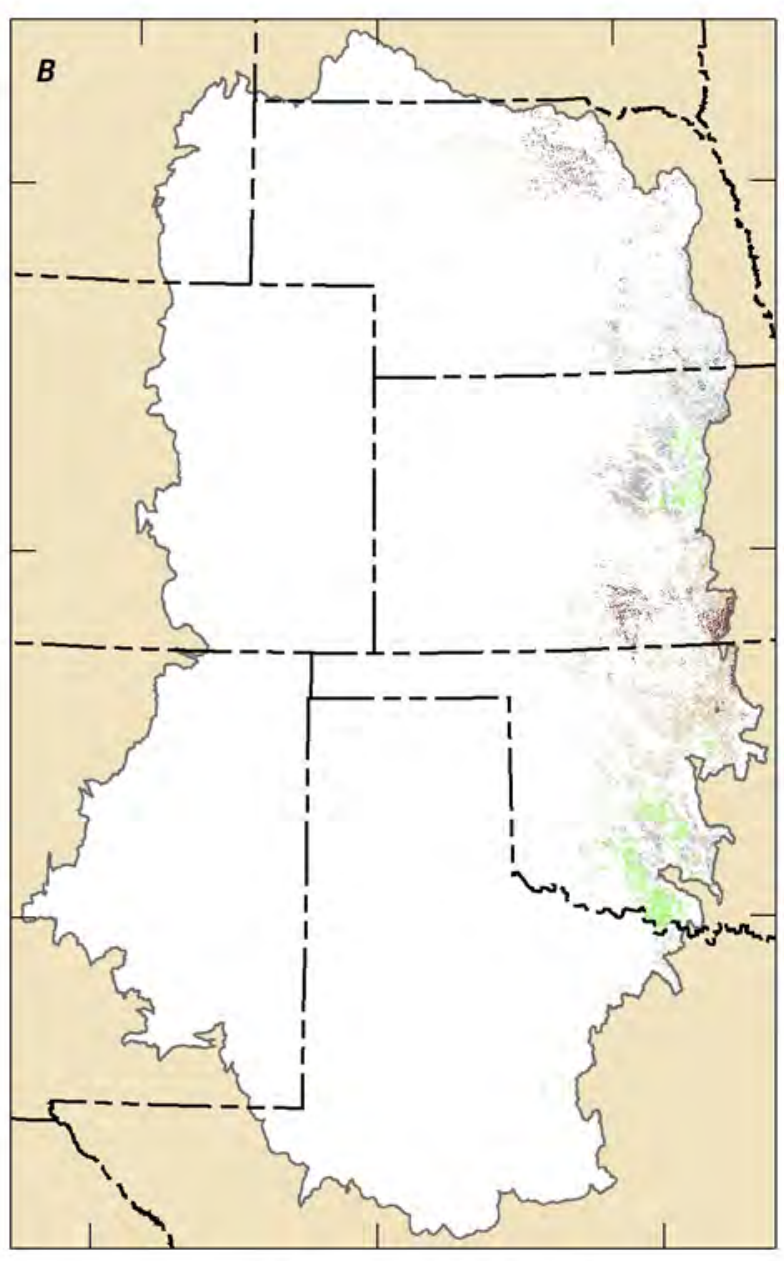

Base map from U.S. Geological Survey National Map, 1:12,635,439

North American Albers Equal Area Conic projection North American Datum of 1983 Central Meridian $-102^{\circ} \mathrm{W}$.

Standard Parallels $20^{\circ} \mathrm{N}$. and $60^{\circ} \mathrm{W}$.
Species trend

Both increasing

One increasing, one stable

Both stable or mixed

One decreasing, one stable

Both decreasing

Figure 15. Predicted changes in productivity for Sorghastrum nutans (Indiangrass) and Andropogon gerardii (big bluestem) within the current distribution of tallgrass prairie in the Southern Great Plains of the United States for $A$, hot-dry; and $B$, hot-wet climate scenarios. Areas without color (white) are outside the current distribution of tallgrass prairie. 
A. Semi-desert grassland species

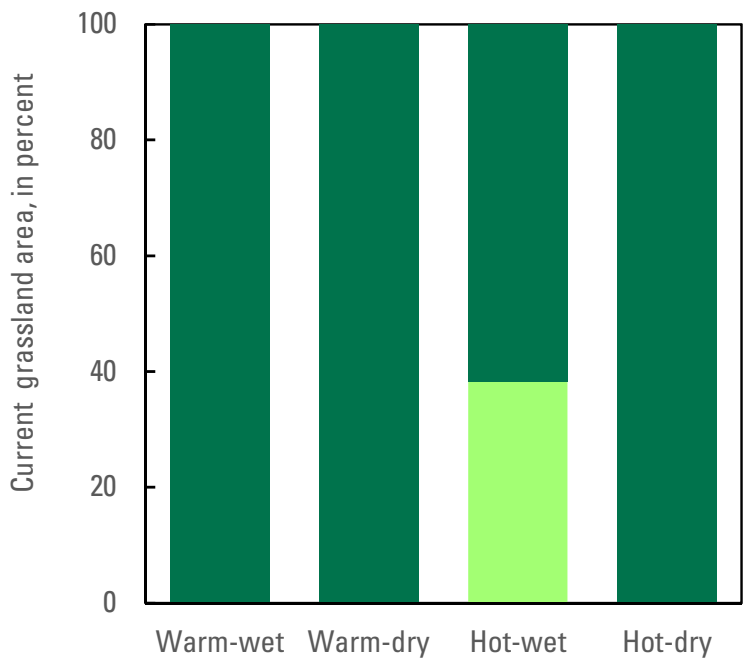

C. Mixed-grass prairie species

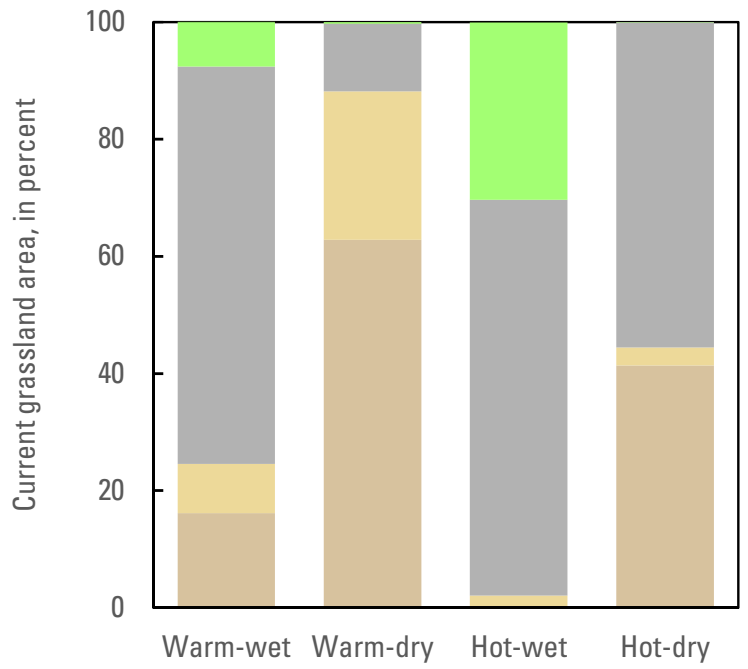

B. Shortgrass prairie species

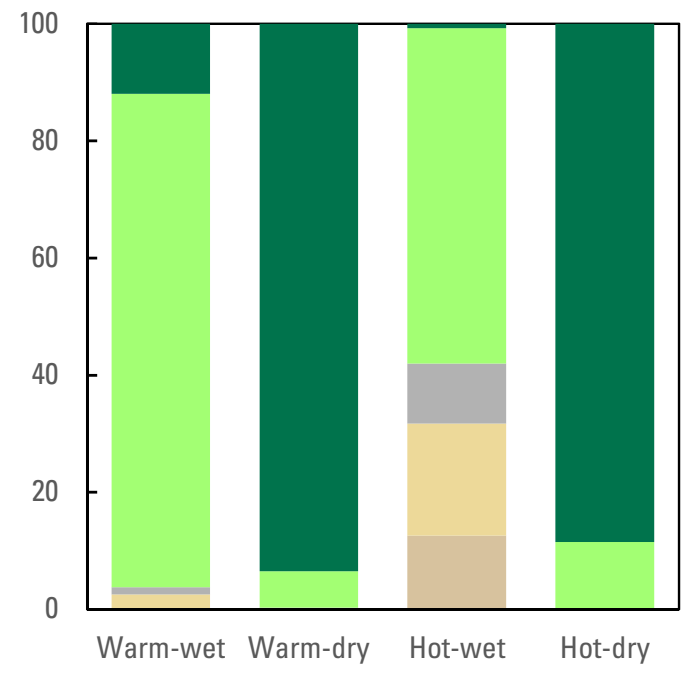

$D$. Tallgrass prairie species

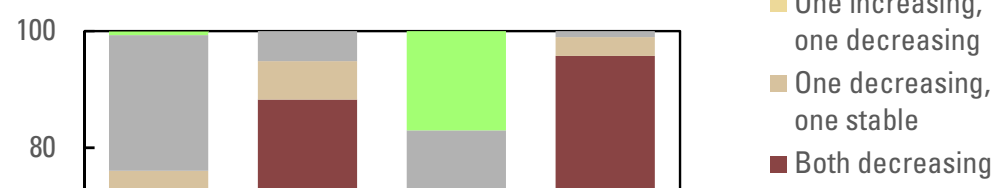

Figure 16. Predicted changes in productivity of two indicator species for each grassland community within the current distribution of the community for each climate scenario in the Southern Great Plains of the United States for $A$, semi-desert grasslands; $B$, shortgrass prairie; $C$, mixed-grass prairie; and $D$, tallgrass prairie. 


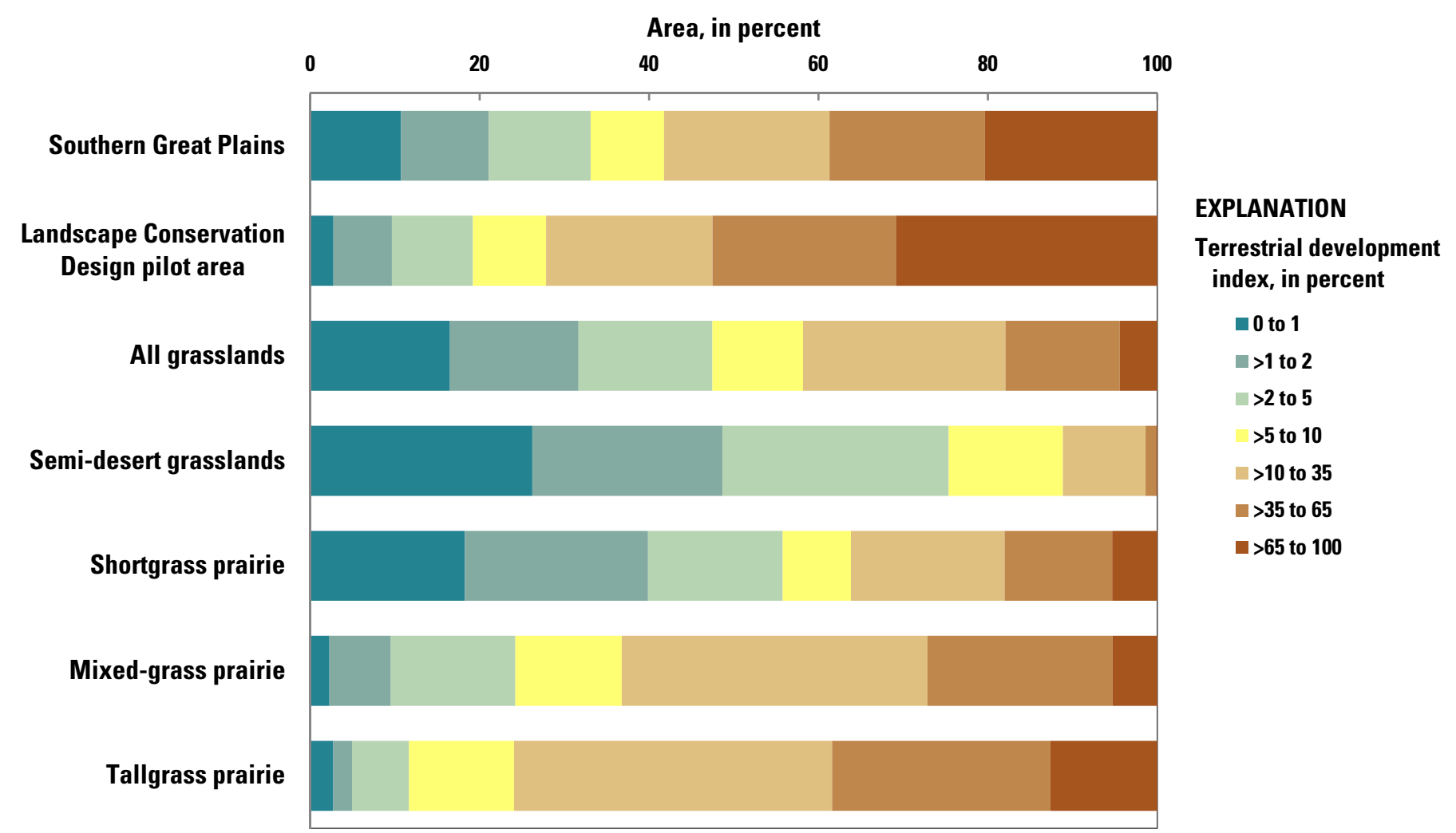

Figure 17. Cumulative effects of development in grassland communities of the Southern Great Plains and the Landscape Conservation Design pilot area. The terrestrial development index (TDI) represents the surface disturbance footprint from development (croplands, roads, energy and minerals, and urban areas) within a 2.5-kilometer $(\mathrm{km})$ radius moving window (Reese and others, 2017). All grasslands includes all grassland communities within the Southern Great Plains (fig. 1A). See figure $1 B$ for the map of TDI for the Southern Great Plains.

atmospheric conditions (such as relative humidity and carbon dioxide $\left[\mathrm{CO}_{2}\right]$ concentration) may offset the effect of precipitation in a manner not accounted for in our models. Compounding the potential effects of greater vulnerability to increasing temperatures coupled with decreasing precipitation, the mixed-grass and tallgrass prairies have been greatly fragmented and converted, primarily by agriculture. These results suggest that the synergistic effects of land use and changing climatic conditions would have the greatest effects on the composition and structure of mixed-grass and tallgrass prairies in the SGP.

In contrast, our results suggest that the climate scenarios evaluated most frequently indicate stable or increasing productivity (low vulnerability) of the indicator species in semi-desert grasslands and shortgrass prairie, as well as sideoats grama in mixedgrass prairie. The only exception was blue grama, for which a decrease in relative productivity was predicted in the southeastern SGP for the wetter scenarios, outside of most areas where it is currently co-dominant. In addition, conversion and fragmentation of semi-desert grasslands and shortgrass prairie was relatively low. The results suggest that many shorter grass species have the potential to maintain their prevalence or possibly expand in response to the climate scenarios evaluated.

The climate of the SGP has been highly variable over time leading to variation in water availability, and because grass species vary in their response to climate cycles, these dynamics contribute to variation in species composition and structural dynamics (Salley and others, 2016). The shorter sod-forming grass species are well-adapted to high temperatures and periodic drought conditions due to physiology that enhances precipitation use efficiency (Sims 1988; Vermeire and others, 2009) and below-ground, versus above-ground, biomass production (Lane and others, 2000). One potential outcome of such variation in drought tolerance is a shift in the diversity of grass heights in mixed-grass prairie towards the shorter grasses if precipitation decreases and (or) drought frequency and duration increases. 


\section{Uncertainty in Future Distribution, Structure, and Composition of Grassland Communities}

Analysis based on scenarios is useful for evaluating the potential effects of possible future climate conditions on the bioclimatic conditions suitable for the indicator grass species, but whether these changes will lead to shifts in abundance, dominance, and distributions of grass species and associated communities cannot be accurately predicted given ecological complexity and uncertainty surrounding future conditions. The diversity of species, and heterogeneity in species composition across the landscape, make interpreting potential changes in the grassland communities challenging when using a few representative species. In addition, the current distributions of shortgrass and mixed-grass prairies are widespread within the SGP, whereas the distributions of semi-desert grasslands and tallgrass prairie are more extensive outside of the SGP (Sims, 1988; Knapp and Seasted, 1998). Consequently, the area of analysis does not fully capture the potential changes in distribution of bioclimatic conditions conducive to indicator species of semi-desert grasslands and tallgrass prairie. Furthermore, there are several aspects of uncertainty and complexity in climate modeling and bioclimatic distribution models that lead to uncertainty in climate projections and the potential responses of biotic communities to a changing climate (for example, see Sofaer and others, 2017). Because of these limitations, it is not valid to use the predictions in productivity provided here to predict precise locations of ecological communities in the future. Rather, the potential for shifts, expansion, or contraction of indicator species based on climate conditions can provide an index of potential changes to the grassland communities that can inform management options. Below, we discuss some of the major sources of uncertainty that are important to consider when applying the results of scenario analysis to management decisions.

Although considerable progress has been made in GCMs for modeling precipitation, uncertainty remains in projections of the amount and regional distribution of precipitation, in particular the frequency and magnitude of drought (Randall and others, 2007) and this uncertainty can influence the model results presented here (Wiens and others, 2009). This underscores the challenges in predicting the productivity and distribution of grass species, which vary considerably in their capacity to withstand and recover from drought (Ban and others, 2014; Liu and others, 2017). Our results demonstrated the capacity of precipitation to either exacerbate or ameliorate the potential effects of increasing temperatures on the direction and magnitude of change in the predicted productivity for several grass species in the SGP.

The bioclimatic models based on climate and soils do not address the potential consequences of increasing $\mathrm{CO}_{2}$ and biotic interactions for the productivity, abundance and distribution of grass species. The concentration of atmospheric $\mathrm{CO}_{2}$ is associated with water-use and nutrient-use efficiency of grasses and increased concentration of $\mathrm{CO}_{2}$ in the atmosphere can affect the productivity and competitive abilities of grass species (Wullschleger and others, 2001; Dijkstra and others, 2010; Zelikova and others, 2014). Likewise, the effects of climate on shrub species that are currently of management concern in the SGP can alter the structure and function of grassland communities. For example, the response of sagebrush and sand shinnery oak to changing climates can affect the composition and structure of sand prairie communities, which provide crucial habitat for the Tympanuchus pallidicinctus (lesser prairie chicken). Similarly, the ongoing expansion of Prosopis glandulosa (honey mesquite) into semi-desert grasslands and mixed-grass prairies and the expansion of Juniperus virginiana (eastern redcedar) into tall and mixed-grass communities could compound the vulnerability of prairie grasslands particularly if conditions suitable for these species expand. Both species can negatively affect grass production (Wilson and others, 2001; Fredrickson and others, 2006; Ansley and others, 2013), and honey mesquite is resistant and resilient to drought because of its laterally extensive and deep root structure (Wilson and others, 2001). In addition, herbivory can play a major role in determining how changing bioclimatic conditions influence the structure and composition of grassland communities (for example see, Bush and Van Auken, 2010). Biotic interactions can also be affected by future land uses including land management practices such as grazing and fire (Milchunas and others, 1989; LeCain and others, 2012).

Despite the uncertainty associated with climate and bioclimatic modeling, the vulnerability gradients for each community were generally consistent across the climate scenarios evaluated (fig. 16), with the exception of the hot-wet scenario. For the shorter grass species, the magnitude and prevalence of the predicted changes in productivity varied along a continuum, with the greatest potential changes predicted for both indicator species of the semi-desert grasslands and stable or limited increases in productivity for sideoats grama. Likewise, the potential contraction of suitable bioclimate conditions for taller grass species was less for little bluestem and greater for big bluestem and Indiangrass. The hot-wet scenario was an exception to this pattern-it suggested greater stability for the taller grasses than other scenarios. The projected effects of different climate scenarios were generally consistent within the four different communities, with only a few exceptions, suggesting that the overall predicted outcomes may not be particularly sensitive to the particular scenario selected (fig. 16). This suggests that management actions designed to offset these vulnerabilities would be robust to the selection of climate scenarios. 


\section{Management Implications}

Given the limited distribution and potential for changes in species' productivity in mixed-grass and tallgrass prairies of the SGP based on current patterns of land use, and the small amount of public and protected lands in these communities, there are limited management opportunities to promote resistance and resilience to changing climates. Understanding of the distribution of habitat availability and ecological conditions across the landscape could be used to guide management of public and private lands. The Conservation Reserve Program (CRP; NRCS, 2018) may provide a viable strategy for providing incentives to private land owners to plant native species in agricultural lands. If a set of criteria was developed to prioritize lands based on ecological potential and the landscape context of public and private lands in this region, enhancement of the size and connectivity of mixed-grass and tallgrass prairie may be accomplished. An incentive program could then use recommendations of species composition and location based on landscape assessment to guide habitat restoration. Based on potential for changes in the suitable climatic conditions, recommendations of species composition and restoration goals that reflect climate trends may be warranted. In addition, recommended native seed mixtures could be developed and tied to incentives to encourage the use of such seed mixes on public and private lands.

\section{Potential Implications for Landscape Conservation Design}

The Great Plains LCD area is primarily short-grass prairie intermixed with extensive sand prairie (including sand sagebrush and shinnery oak), and semi-desert grasslands (fig $1 A$ and table 1). The spatial extent of the LCD facilitates a specific landscape application of the results of the scenario analysis. The predicted increase in productivity of blue grama and buffalograss (shortgrass prairie) for most of the scenarios evaluated indicate the potential for resilience and resistance of the shortgrass prairie within the LCD area. In contrast, decreased production of big bluestem and Indiangrass, and sustained or increased production from short- and mid-height grasses could cause a shift in composition and structure in the sand prairie communities. Production of sideoats grama, however, was not predicted to change for any scenarios within the LCD area, and this result, coupled with local importance, suggests that production of sideoats grama could offset changes in other species. Furthermore, the potential for increased productivity of black grama and tobosagrass could result in expansion of the semi-desert grasslands. The LCD area is along the eastern extent of the shortgrass prairie where development levels in this community are relatively high (fig. 1B). In conjunction with information on land use (figs. $1 B$ and 17), results from the climate scenarios suggest potential opportunities for conservation and habitat management within the LCD area in the future.

\section{Conclusions}

The modeled scenarios presented here provide insights into the possible implications of four divergent but plausible future climate scenarios for changes in relative productivity of species across the region. The results of the scenario analysis indicate relatively low vulnerability for semi-desert grasslands and shortgrass prairie compared to mixed-grass and tallgrass prairie. Vulnerability of tallgrass prairie is relatively high because of the potential sensitivity of indicator species to the climate scenarios evaluated, as well as reduced adaptive capacity resulting from conversion by agriculture. Private-lands conservation programs, such as the Conservation Reserve Program, may play an important role in the management and conservation of mixed-grass and tallgrass prairies by addressing potential changes in productivity of some species, and addressing the landscape distribution of plant communities. The results of our analysis could be helpful for prioritizing locations and species composition for habitat management on private lands, for example through the CRP, and public lands that could enhance the connectivity of prairie grasslands, and supplement current conservation areas. 


\section{References Cited}

Ansley, R.J., Mirik, M., Heaton, C.B., and Wu, X.B., 2013, Woody cover and grass production in a mesquite savanna: Geospatial relationships and precipitation: Rangeland Ecology and Management, v. 66, p. 621-633.

Ban, N., Schmidli, J., and Schär, C., 2014, Evaluation of the convection-resolving regional climate modeling approach in decade-long simulations: Journal of Geophysical Research-Atmospheres: v. 119, p. 7889-7907, accessed October 2017, at https://doi.org/10.1002/2014JD021478.

Barnes, P.W. and Harrison, A.T., 1982, Species distribution and community organization in a Nebraska Sandhills mixed prairie as influences by plant/soil-water relationships: Oecologia, v. 52, p. 192-201. [Also available at https://ink.springer.com/ article/10.1007/BF00363836.]

Bartuszevige, A.M., Taylor, K., Daniels, A., Carter, M.F., 2016, Landscape design-Integrating ecological, social, and economic considerations into conservation planning: Wildlife Society Bulletin, v. 40, p. 411-422, accessed July 2017, at https://doi.org/10.1002/wsb.683.

Berg, W.A., Bradford, J.A., and Sims, P.L., 1997, Long-term soil nitrogen and vegetation change on sandhill rangeland: Journal of Range Management, v. 50, p. 482-486. [Also available at https://www.jstor.org/stable/4003702.]

Briggs, J.M. and Knapp, A.K., 1995, Interannual variability in primary production in tallgrass prairie-Climate, soil-moisture, topographic position, and fire as determinants of aboveground biomass: American Journal of Botany, v. 82, p. 1024-1030. [Also available at https://doi.org/10.1002/j.1537-2197.1995.tb11567.x.]

Broska, J., 2013, Great Plains LCC_-Landscape Conservation Design Pilot: U.S. Fish and Wildlife Service, Great Plains Landscape Conservation Cooperative, accessed March 2017, at https://www.sciencebase.gov/catalog/item/53ac958be4b0dad35f8e8d64.

Bush, J.K. and VanAuken, O.W., 2010, Competition between Schizachyrium scoparium and Buchloë dactyloides-The role of soil nutrients: Journal of Arid Environments, v. 74, p. 49-53. [Also available at https://doi.org/10.1016/j.jaridenv.2009.07.012.]

Chapin, F.S., Matson, P.A. and Mooney, H.A., 2002, Terrestrial water and energy balance. chap, 4 of Principles of Terrestrial Ecosystem Ecology: Springer Science+Business Media, Inc., New York, p. 71-96.

Collier, M., and Uhe, P., 2012, CMIP5 datasets from the ACCESS1.0 and ACCESS1.3 coupled climate models: Centre for Australian Weather and Climate Research Technical Report no. 059, 25 p. [Also available at http://citeseerx.ist.psu.edu/viewdoc/ download?doi=10.1.1.710.4998\&rep=rep1\&type=pdf.]

Connor, R., Seidl, A., Van Tassell, L., and Wilkins, N., 2001, United States grasslands and related resources-An economic and biological trends assessment: Texas A\&M, Natural Resources Institute, College Station, Tex., 170 p. [Also available at https://irnr.tamu.edu/ publications/research-reports/2001/united-states-grasslands-and-related-resources-an-economic-and-biological-trends-assessment.]

Coupled Model Intercomparison Project [CMIP5], 2013, The CMIP5 multi-model ensemble: World Climate Research Programme, Phase 5, accessed December 2015, at https://esgf-node.llnl.gov/search/cmip5/.

Dijkstra, F.A., Blumenthal, D.M., Morgan, J.A., LeCain, D.R., and Follett, R.F., 2010, Elevated $\mathrm{CO}_{2}$ effects on semi-arid grassland plants in relation to water availability and competition: Functional Ecology, v. 24, p. 1152-1161. [Also available at https://doi.org/10.1111/j.1365-2435.2010.01717.x.]

Earth System Science Center, 2016, Soil information for environmental modeling and ecosystem management—University Park, Penn., CONUS-Soil, Data Coverages, Soil Texture Class: College of Earth and Mineral Sciences, Pennsylvania State University, accessed January 2016, at http://www.soilinfo.psu.edu/index.cgi?soil_data\&conus\&data_cov\&fract\&datasets\&alb.

Epstein, H.E., Lauenroth, W.K., Burke, I.C. and Coffin, D.P., 1998, Regional productivities of plant species in the Great Plains of the United States: Plant Ecology, v. 134, p. 173-195. [Also available at https://link.springer.com/article/10.1023/A:1009732800810.]

Fisichelli, N.A., Schuurman, G.W., Hoffman, C.H., 2016, Is "resilience" malaptive? Towards an accurate lexicon for climate change adaptation: Environmental Management v. 57, p. 753-758, accessed August 2018, at https://link.springer.com/article/10.1007/ s00267-015-0650-6.

Fredrickson, E.L., Estell, R.E., Laliberte, A., and Anderson, D.M., 2006, Mesquite recruitment in the Chihuahuan desert—Historic and prehistoric patterns with long-term impacts: Journal of Arid Environments, v. 65, p. 285-295. [Also available at https://doi. org/10.1016/j.jaridenv.2005.10.019.] 
Freeman, C.C. 1998, The flora of Konza prairie-A historical review and contemporary patterns, in Knapp, A.K., Briggs, J.M., Harnett, D.C. and Collins, S.L., eds., Grassland dynamics: New York, Oxford University Press, p. 69-80.

Gillen, R.L. and Sims, P.L., 2004, Stocking rate, precipitation and herbage production on sage sagebrush-grassland: Journal of Range Management, v. 57, p. 148-152. [Also available at https://www.jstor.org/stable/4003912.]

Gross, J.E., Woodley, S., Welling, L.A., and Watson J.E.M., eds., 2016, Assessing climate change vulnerability and risk, chap. 4 of Adapting to climate change - Guidance for protected area managers and planners: International Union for the Conservation of Nature and Natural Resources [IUCN], Best Practice Protected Area Guidelines Series, no. 24, Gland Switzerland, xviii + 129 p. [Also available at: https://portals.iucn.org/library/sites/library/files/documents/PAG-024.pdf.]

Gonzalez, P., Neilson, R.P., Lenihan, J.M., and Drapek, R.J., 2010, Global patterns in the vulnerability of ecosystems to vegetation shifts due to climate change: Global Ecology and Biogeography v. 19, p. 755-768. [Also available at https://doi.org/10.1111/j.1466-8238.2010.00558.x.]

Great Plains Landscape Conservation Cooperative, 2011, Great Plains Landscape Conservation Cooperative Charter: U.S. Fish and Wildlife Service, accessed Oct. 2017, at https:/greatplainslcc.org/resource/great-plains-lcc-charter.

Harrell, W.C., Fuhlendorf, S.D., and Bidwell, T.G., 2001, Effects of prescribed fire on sand shinnery oak communities: Journal of Range Management, v. 54, p. 685-690. [Also available at https://www.jstor.org/stable/4003672.]

Hayden, B.P., 1998, Regional climate and distribution of tallgrass prairie, in Knapp, A.K., Briggs, J.M., Harnett, D.C., and Collins, S.L., eds., Grassland dynamics-Long-term ecological research in tallgrass prairie, Long-term ecological research network series: New York, Oxford University Press, Inc., p. 19-34.

Heikkinen, R.K., Luoto, M., Araújo, M.B., Virkkala, R., Thuiller, W., and Sykes, M.T., 2006, Methods and uncertainties in bioclimatic envelope modelling under climate change: Progress in Physical Geography, v. 30, p. 751-777. [Also available at https://doi.org/10.1177/0309133306071957.]

Knapp, A.K., and Seasedt, T.R., 1998, Introduction—Grasslands, Konza prairie and long-term ecological research, in Knapp, A.K. Briggs, J.M., Harnett, D.C., and Collins, S.L., eds., Grassland dynamics-Long-term ecological research in tallgrass prairie, Long-term ecological research network series: New York, Oxford University Press, p. 3-18.

Lane, D.R., Coffin, D.P., and Lauenroth, W.K., 2000, Changes in grassland canopy structure across a precipitation gradient: Journal of Vegetation Science, v. 11, p. 359-368. [Also available at https://doi.org/10.2307/3236628.]

Lauenroth, W.K., Schlaepfer, D.R. and Bradford, J.B., 2014. Ecohydrology of dry regions-Storage versus pulse soil water dynamics: Ecosystems, v. 17, p. 1469-1479. [Also available at https://link.springer.com/article/10.1007/s10021-014-9808-y.]

LeCain, D.R., Morgan, J.A., Hutchinson, G.L., Reeder, J.D., and Dijkstra, F.A., 2012, Interactions between elevated atmospheric $\mathrm{CO}_{2}$ and defoliation on North American rangeland plant species at low and high N availability: Grass and Forage Science: v. 67, p. 350-360. [Also available at https://doi.org/10.1111/j.1365-2494.2011.00847.x.]

Liu, C., Ikeda, K., Rasmussen, R., Barlage, M., Newman, A.J., Prein, A.F., Chen, F., Chen, L., Clark, M., Dai, A., Dudhia, J., Eidhammer, T., Gochis, D., Gutmann, E., Kurkute, S., Li, Y., Thompson, G., and Yates, D., 2017, Continental-scale convection-permitting modeling of the current and future climate of North America: Climate Dynamics, v. 49, p. 71-95, accessed October 2017, at https://link.springer.com/article/10.1007/s00382-016-3327-9.

Manier, D.J., Carr, N.B., Reese, G.C., and Burris, L.E., 2019, Potential productivity and change estimates for eight grassland species to evaluate vulnerability to climate change in the southern Great Plains: U.S. Geological Survey data release, https:// doi.org/10.5066/P9DGJHEP.

Martinson, E.J., Eddy, Z.B., Commerford, J.L., Blevins, E., Rolfsmeier, S.J., and McLauchlan, K.K., 2011, Biogeographic distributions of selected North American grassland plant species: Physical Geography, v. 32, p. 583-602. [Also available at https://doi.org/10.2747/0272-3646.32.6.583.]

Maurer, E.P., Wood, A.W., Adam, J.C., Lettenmaier, D.P., and Nijssen, B., 2002, A long-term hydrologically based dataset of land surface fluxes and states for the conterminous United States: Journal of Climate, v. 15, p. 3237-3251. [Also available at https://doi.org/10.1175/1520-0442(2002)015<3237:ALTHBD>2.0.CO;2.] 
Milchunas, D.G., Lauenroth, W.K., Chapman, P.L., and Kazempour, M.K., 1989, Effects of grazing, topography, and precipitation on the structure of a semiarid grassland: Vegetatio, v. 80, p. 11-23. [Also available at https://link.springer.com/article/10.1007/BF00049137.]

Miller, B.W., Symstad, A.J., Frid, L., Fisichelli, N. A., and Schuurman, G.W., 2017, Co-producing simulation models to inform resource management-A case study from southwest South Dakota: Ecosphere v. 8, no. 12, e02020, accessed October 2018, at https://esajournals.onlinelibrary.wiley.com/doi/pdf/10.1002/ecs2.2020.

National Park Service, 2013, Using scenarios to explore climate change-A handbook for practitioners: Fort Collins, Colo., National Park Service Climate Change Response Program, 57 p., accessed July 2015, at https://www.nps.gov/subjects/ climatechange/upload/CCScenariosHandbookJuly2013.pdf.

Natural Resources Conservation Service (NRCS), 2016, Ecological Site Inventory System (ESIS): U.S. Department of Agriculture, Natural Resources Conservation Service, accessed December 2016, at https://esi.sc.egov.usda.gov/ESI_Rangeland/frmPlantSpecies.aspx.

Natural Resources Conservation Service (NRCS), 2017, Plant Fact Sheets: U.S. Department of Agriculture, Natural Resources Conservation Service, accessed September 2017, at https://plants.usda.gov.

Natural Resources Conservation Service (NRCS), 2018, Conservation Reserve Program: U.S. Department of Agriculture, Natural Resources Conservation Service, accessed January 2018, at https:/www.nrcs.usda.gov/wps/portal/nrcs/detail/national/ programs/?cid=stelprdb1041269.

Neale, R.B., Chen, C., Gettelman, A., Lauritzen, P.H., Park, S., Williamson, D.L., Conley, A.J., Garcia, R., Kinnison, D., Lamarque, J.-F., Marsh, D., Mills, M., Smith, A.K., Tilmes, S., Vitt, F., Morrison, H., Cameron-Smith, P., Collins, W.D., Iacono, M.J., Easter, R.C., Ghan, S.J., Liu, X., Rasch, P.J., and Taylor, M.A., 2012, Description of the NCAR Community Atmosphere Model (CAM 5.0) - National Center for Atmospheric Research Technical Note: National Center for Atmospheric Research, NCAR/TN-486+STR, 274 p. [Also available at http://www.cesm.ucar.edu/models/cesm1.0/cam/docs/description/ cam5_desc.pdf.]

Oklahoma Department of Wildlife Conservation, 2016, Oklahoma current vegetation mapping: Oklahoma Department of Wildlife Conservation, Oklahoma Biological Survey and University of Missouri Resource Assessment Partnership, accessed September 2016, at https://morap.missouri.edu/index.php/oklahoma-current-vegetation-mapping/.

Omernik, J.M., 1987, Ecoregions of the conterminous United States: Annals of the Association of American Geographers v. 77, no. 1, p. 118-125. [Also available at https://doi.org/10.1111/j.1467-8306.1987.tb00149.x.]

Pearson, R.G., and Dawson, T.P., 2003, Predicting the impacts of climate change on the distribution of species-Are bioclimatic envelope models useful?: Global Ecology and Biogeography, 12, p. 361-371. [Also available at https://doi.org/10.1046/ j.1466-822X.2003.00042.x.]

Peterson, G.D., Cumming, G.S. and Carpenter, S.R., 2003, Scenario Planning-A tool for conservation in an uncertain world: Conservation Biology, v. 17, p. 358-366. [Also available at https://doi.org/10.1046/j.1523-1739.2003.01491.x.]

Porensky, L.M., Derner, J.D., Augustine, D.J., and Milchunas, D.G., 2017, Plant community composition after 75 yr of sustained grazing intensity treatments in shortgrass steppe: Rangeland Ecology and Management, v. 70, p. 456-464, accessed October 2017, at https://doi.org/10.1016/j.rama.2016.12.001.

Randall, D.A., Wood, R.A., Bony, S., Colman, R., Fichefet, T., Fyfe, J., Kattsov, V., Pitman, A., Shukla, J., Srinivasan, J., Stouffer, R.J., Sumi, A., and Taylor, K.E., 2007, Climate models and their evaluation, chap. 8, of Solomon, S., Quin, D., Manning, M., Chen, Z., Marquis, M., Averyt, K.B., Tignor, M.M.B., and Miller, H.L., Jr., eds., Climate change 2007-The Physical Science Basis, Contribution of Working Group I to the fourth assessment report of the Intergovernmental Panel on Climate Change: Cambridge, U.K., and New York, Cambridge University Press, p. 589-662.

Reese, G.C., Burris, L., Carr, N.B., Leinwand, I.I.F., and Melcher, C.P., 2017, Southern Great Plains rapid ecoregional assessment, volume I-Ecological communities: U.S. Geological Survey Open-File Report 2017-1100, 129 p., accessed December 2017, at https://doi.org/10.3133/ofr20171100.

Salley, S.W., Sleezer, R.O., Bergstrom, R.M., Martin, P.H., and Kelly, E.F., 2016, A long-term analysis of the historical dry boundary for the Great Plains of North America-Implications of climate variability and climatic change on temporal and spatial patterns in soil moisture: Geoderma, v. 274, p. 104-113, accessed March 2017, at https://doi.org/10.1016/j.geoderma.2016.03.020. 
Schmidt, G.A., Kelley, M., Nazarenko, L., Ruedy, R., Russell, G.L., Aleinov, I., Bauer, M., Bauer, S.E., Bhat, M.K., Bleck, R., Canuto, V., Chen, Y.-H., Cheng, Y., Clune, T.L., Del Genio, A., de Fainchtein, R., Faluvegi, G., Hansen, J.E., Healy, R.J., Kiang, N.Y., Koch, D., Lacis, A.A., LeGrande, A.N., Lerner, J., Lo, K.K., Matthews, E.E., Menon, S., Miller, R.L., Oinas, V., Oloso, A.O., Perlwitz, J.P., Puma, M.J., Putman, W.M., Rind, D., Romanou, A., Sato, M., Shindell, D.T., Sun, S., Syed, R.A., Tausnev, N., Tsigaridis, K., Unger, N., Voulgarakis, A., Yao, M.-S., and Zhang, J., 2014, Configuration and assessment of the GISS ModelE2 contributions to the CMIP5 archive: Journal of Advances in Modeling Earth Systems, 6, no. 1, p. 141-184, accessed January 2017, at https://doi.org/10.1002/2013MS000265.

Schoeneberger, P.J., Wysocki, D.A, Benham, E.C., and Broderson, W.D., eds., 2002, Field book for describing and sampling soils, ver. 2: Lincoln, Neb., Natural Resources Conservation Service, National Soil Survey Center, 220 p.

Sims, P.L., 1988, Grasslands, chap. 9 of Barbour, M.G., and Billings, W.D., eds., North American terrestrial vegetation: New York, Cambridge University Press, p. 265-286.

Singh, J.S., Milchunas, D.G., and Lauenroth, W.K., 1998, Soil water dynamics and vegetation patterns in a semiarid grassland: Plant Ecology, v. 134, p. 77-89. [Also available at https://link.springer.com/article/10.1023/A:1009769620488.]

Sofaer, H.R., Barsugli, J.J., Jarnevich, C.S., Abatzoglou, J.T., Talbert, M.K., Miller, B.W., and Morisette, J.T., 2017, Designing ecological climate change impact assessments to reflect key climatic drivers: Global Change Biology, v. 23, p. 2537-2553. [Also available at https://doi.org/10.1111/gcb.13653.]

Sohl, T.L., Dornbierer, J.M, Wika, S., Sayler, K., and Quenzer, R., 2017, Parcels versus pixels-Modeling agricultural land use across broad geographic regions using parcel-based field boundaries. Journal of Land Use Science 12(4): 197-217, accessed February 2018, at https://doi.org/10.1080/1747423X.2017.1340525.

Symstad, A.J., Fisichelli, N.A., Miller, B.W., Rowland, E., Schuurman, G.W., 2017a, Multiple methods for multiple futuresIntegrating qualitative scenario planning and quantitative simulation modeling for natural resource decision making: Climate Risk Management, v. 17, p. 78-91, accessed October 2017, at https://doi.org/10.1016/j.crm.2017.07.002.

Symstad, A.J., B.W. Miller, J.M. Friedman, N.A. Fisichelli, A.J. Ray, Rowland, E., and Schuurman, G.W., 2017b, Model-based scenario planning to inform climate change adaptation in the northern Great Plains-Final report: U.S. Geological Survey Open File Report 2017-1129, 22 p., accessed October 2017, at: https://doi.org/10.3133/ofr20171129.

Texas Parks and Wildlife, 2016, Ecological mapping systems: Landscape Ecology Program, accessed September 2016, at https://tpwd.texas.gov/landwater/land/programs/landscape-ecology/ems/.]

Vermeire, L.T., Heitschmidt, R.K., and Rinella, M.J., 2009, Primary productivity and precipitation use efficiency in mixed-grass prairie-A comparison of northern and southern U.S. sites: Rangeland Ecology and Management, v. 62, p. 230-239. [Also available at https://doi.org/10.2111/07-140R2.1.]

Watanabe, S., Hajima, T., Sudo, K., Nagashima, T., Takemura, T., Okajima, H., Nozawa, T., Kawase, H., Abe, M., Yokohata, T., Ise, T., Sato, H., Kato, E., Takata, K., Emori, S., and Kawamiya, M., 2011, MIROC-ESM 2010-Model description and basic results of CMIP5-20c3m experiments: Geoscientific Model Development, v. 4, p. 845-872. [Also available at https://www.geosci-model-dev.net/4/845/2011/.]

Weaver, J.E., Albertson, F.W., Allred, B.W., and Heerwagen, A., 1956, Grasslands of the Great Plains- Their nature and use: Lincoln, Neb., Digital Commons, University of Nebraska, Paper 14. [Also available at http://digitalcommons.unl.edu/agronweaver/14.]

Wiens, J.A., Stralberg, D., Jongsomjit, D., Howell, C.A., and Snyder, M.A., 2009, Niches, models, and climate change-Assessing the assumptions and uncertainties, November 17, 2009, in Proceedings: National Academy of Sciences of the United States, v. 106, p. 19729-19736. [Also available at https://doi.org/10.1073/pnas.0901639106.]

Wilson, T.B., Webb, R.H., and Thompson, T.L., 2001, Mechanisms of range expansion and removal of mesquite in desert grasslands of the southwestern United States: Ogden, Utah, U.S. Department of Agriculture, Forest Service, Rocky Mountain Research Station, General Technical Report, RMRS-GTR-81, 23 p.

Wullschleger, S.D., Tschaplinski, T.J., and Norby, R.J., 2002, Plant water relations at elevated $\mathrm{CO}_{2}$ - Implications for water-limited environments: Plant Cell and Environment: v. 25, p. 319-331. [Also available at https://doi.org/10.1046/j.1365-3040.2002.00796.x.]

Zelikova, T.J., Blumenthal, D.M., Williams, D.G., Souza, L., LeCain, D.R., Morgan, J., and Pendall, E., 2014, Long-term exposure to elevated $\mathrm{CO}_{2}$ enhances plant community stability by suppressing dominant plant species in a mixed-grass prairie, October 28, 2014, Proceedings: National Academy of Sciences of the United States, v. 111, p. 15456-15461. [Also available at https://doi.org/10.1073/pnas.1414659111.] 


\section{Appendix 1. Classified Relative Production Estimates}

To facilitate comparisons among models, relative production estimates were classified into bins. Thresholds for displaying species productivity were established by comparing modeled outputs for the contemporary climate (1981-2010) with field observations from ecological mapping (Texas Parks and Wildlife, 2016; Oklahoma Department of Wildlife Conservation, 2016), field measurements of production Natural Resource Conservation Service [NCRS], 2016), current distribution maps (NRCS, 2017) and the estimated historical distribution of grassland communities (Reese and others, 2016). To establish thresholds in distributions of productivity that correspond to the current distribution of indicator species, we compared model results to independent observations and defined class breakpoints such that classes of the modeled productivity estimates closely corresponded to species occurrences. Thus, areas with greatest potential relative productivity of each species are mapped as green and are assumed to represent greater potential for occurrence (figs. A1.1 to A1.8). Areas with very low potential productivity are mapped as grey and are assumed to represent lower likelihood of occurrence (figs. A1.1 to A1.8). We determined these classes using the models of contemporary productivity and retained the class boundaries for scenario projections to maintain consistency and facilitate comparisons. However, grasslands without the species may occur within predicted suitable areas, and areas outside the predicted suitability may include the species. The limitations in these delineations occur because models reflect the potential productivity based on soil maps and modeled climate conditions, thus model results should not be used to infer presence or abundance of the modeled species in all areas with potential (shades of green in figs. A1.1 to A1.8). Comparisons among model results are useful for considering the implications of climate scenarios. 

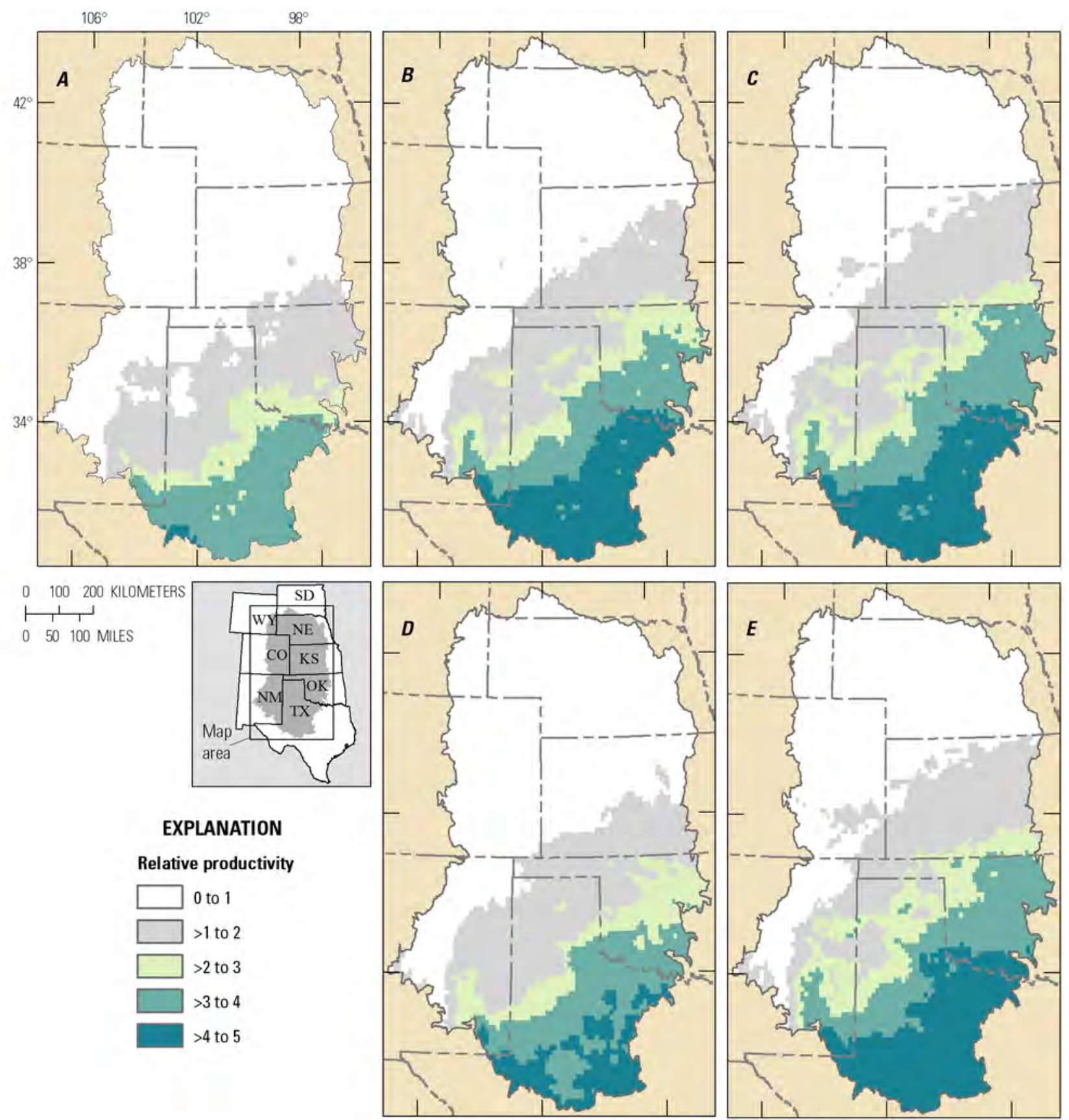

\section{EXPLANATION}

Relative productivity

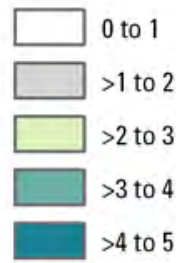

Base map from U.S. Geological Survey, National Map,1:18,883,014 North American Albers Equal Area Conic projection North American Datum of 1983 , Central Meridian - $102^{\circ}$ W., Standard Parallels $20^{\circ} \mathrm{N}$. and $60^{\circ} \mathrm{W}$.

Figure A1.1. Current and predicted relative productivity of Pleuraphis mutica (tobosagrass) using four climate scenarios in the Southern Great Plains of the United States. A, Relative productivity (RP), estimated for contemporary (1981-2010) climatic conditions and predicted relative productivity (scenario forecasts) for: $B$, warm-wet; $C$, hot-wet; $D$, warm-dry; $E$, hot-dry. $\mathrm{RP}=0.08$ (Temp)-0.58, (table 3 ), where Temp is mean annual temperature in degrees Celsius, calculated from 30-year records (contemporary) or simulated conditions (general circulation models [GCM] results). 

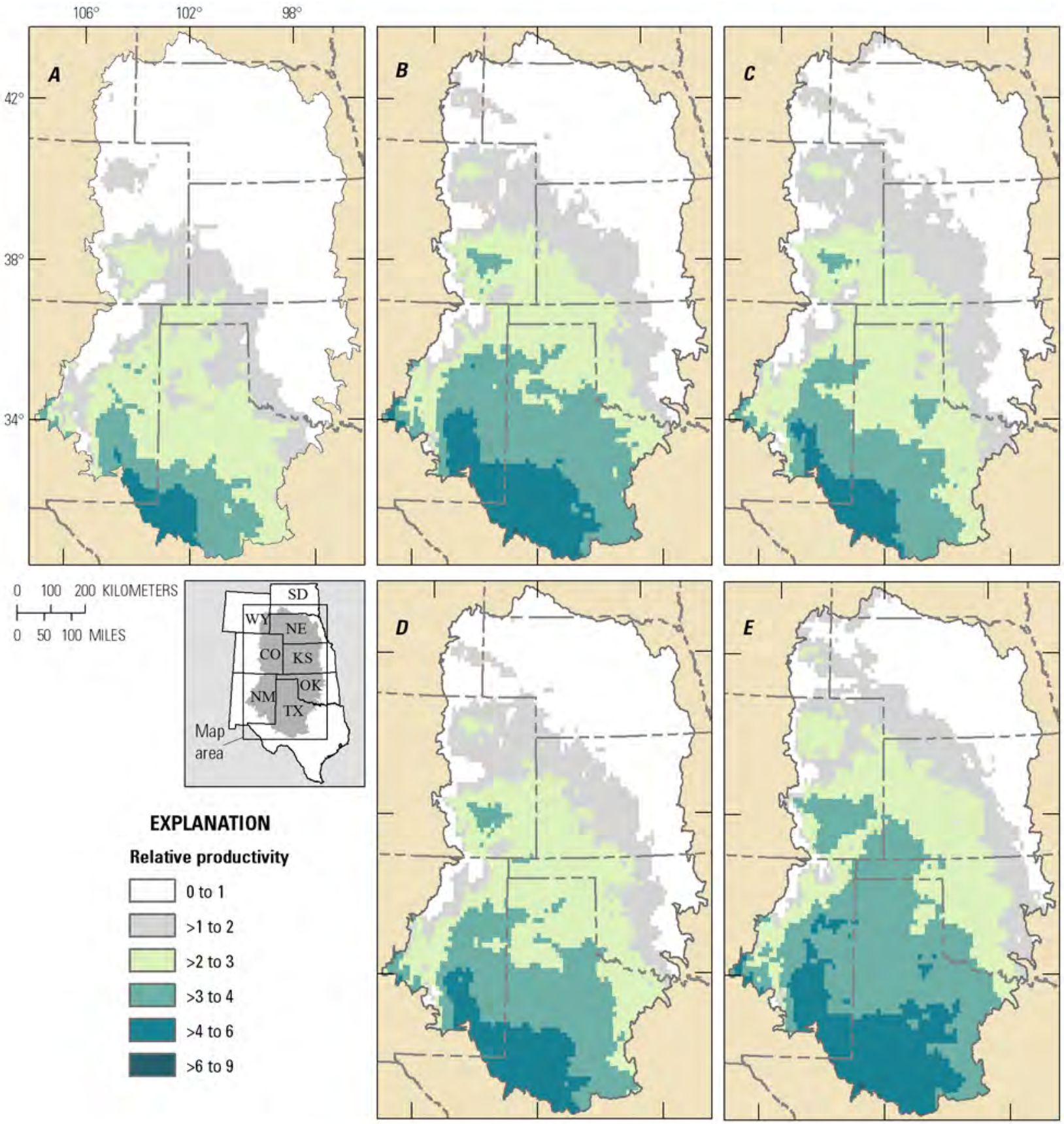

EXPLANATION

Relative productivity

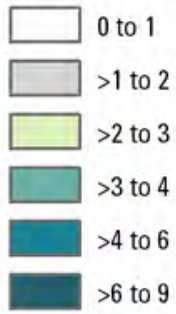

Base map from U.S. Geological Survey, National Map,1:18,883,014

North American Albers Equal Area Conic projection

North American Datum of 1983 , Central Meridian $-102^{\circ}$ W., Standard Parallels $20^{\circ} \mathrm{N}$. and $60^{\circ}$ W.

Figure A1.2. Current and predicted relative productivity of Bouteloua eriopoda (black grama) using four climate scenarios in the Southern Great Plains of the United States. A, Relative productivity (RP) estimated for contemporary (1981-2010) climatic conditions and predicted relative productivity (scenario forecasts) for: $B$, warm-wet; $C$, hot-wet; $D$, warm-dry; $E$, hot-dry. $\mathrm{RP}=0.37$ (Temp)-0.06(Precip)+0.24, (table 3), where Temp is mean annual temperature in degrees Celsius, and Precip is mean annual precipitation in centimeters, calculated from 30 -year records (contemporary) or simulated conditions (general circulation models [GCM] results). 

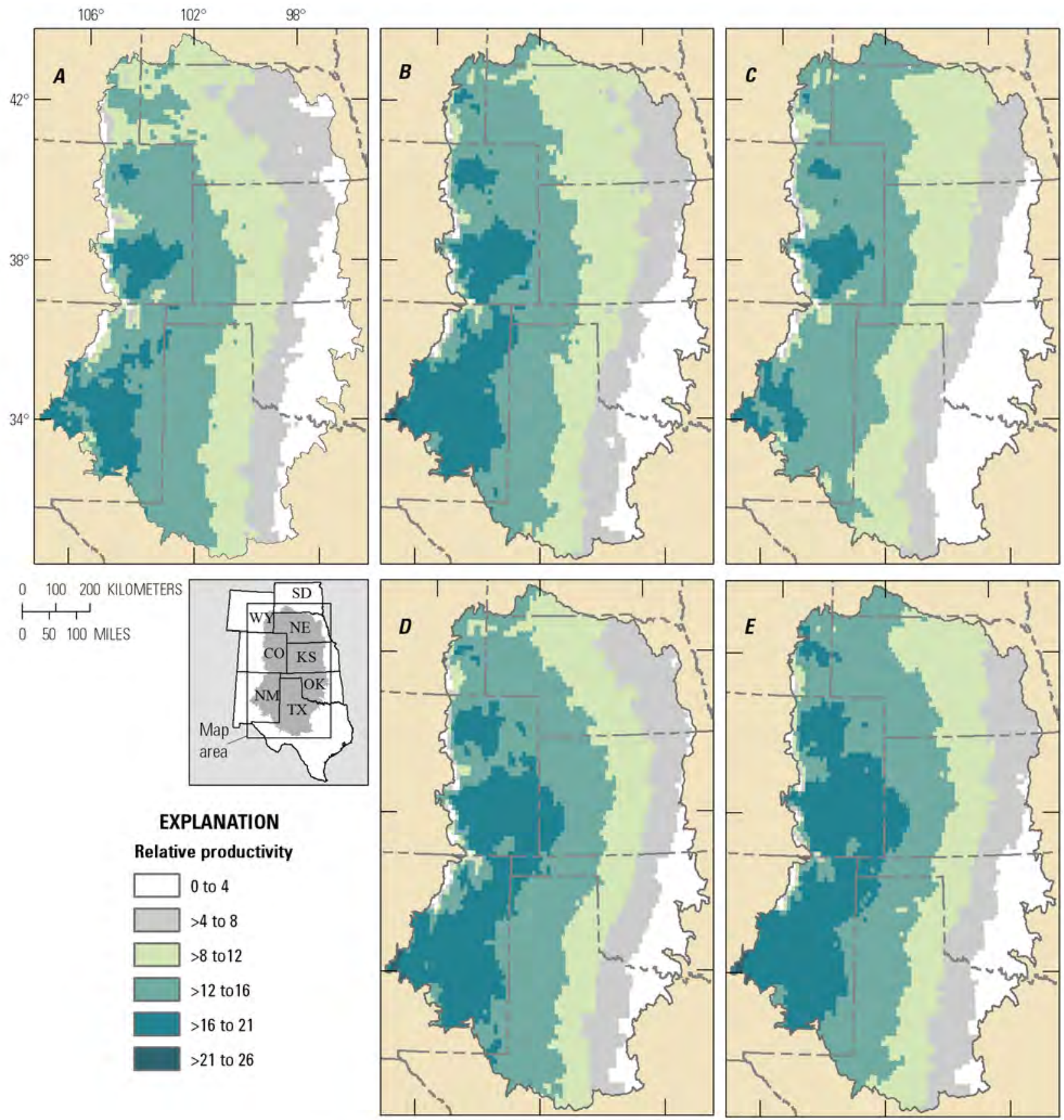

Base map from U.S. Geological Survey, National Map,1:18,883,014

North American Albers Equal Area Conic projection

North American Datum of 1983 , Central Meridian $-102^{\circ}$ W., Standard Parallels $20^{\circ} \mathrm{N}$. and $60^{\circ} \mathrm{W}$.

Figure A1.3. Contemporary and predicted relative productivity of Bouteloua gracilis (blue grama) using four climate scenarios in the Southern Great Plains of the United States. $A$, Relative productivity (RP) estimated for contemporary (1981-2010) climatic conditions and predicted relative productivity (scenario forecasts) for: $B$, warm-wet; $C$, hot-wet; $D$, warm-dry; $E$, hot-dry. $\mathrm{RP}=4.15$ (Temp)-0.3 Precip) $-0.15(\text { Temp })^{2}+0.08$, (table 3 ), where Temp is mean annual temperature in degrees Celsius, and Precip is mean annual precipitation in centimeters, calculated from 30-year records (contemporary) or simulated conditions (general circulation models [GCM] results). 

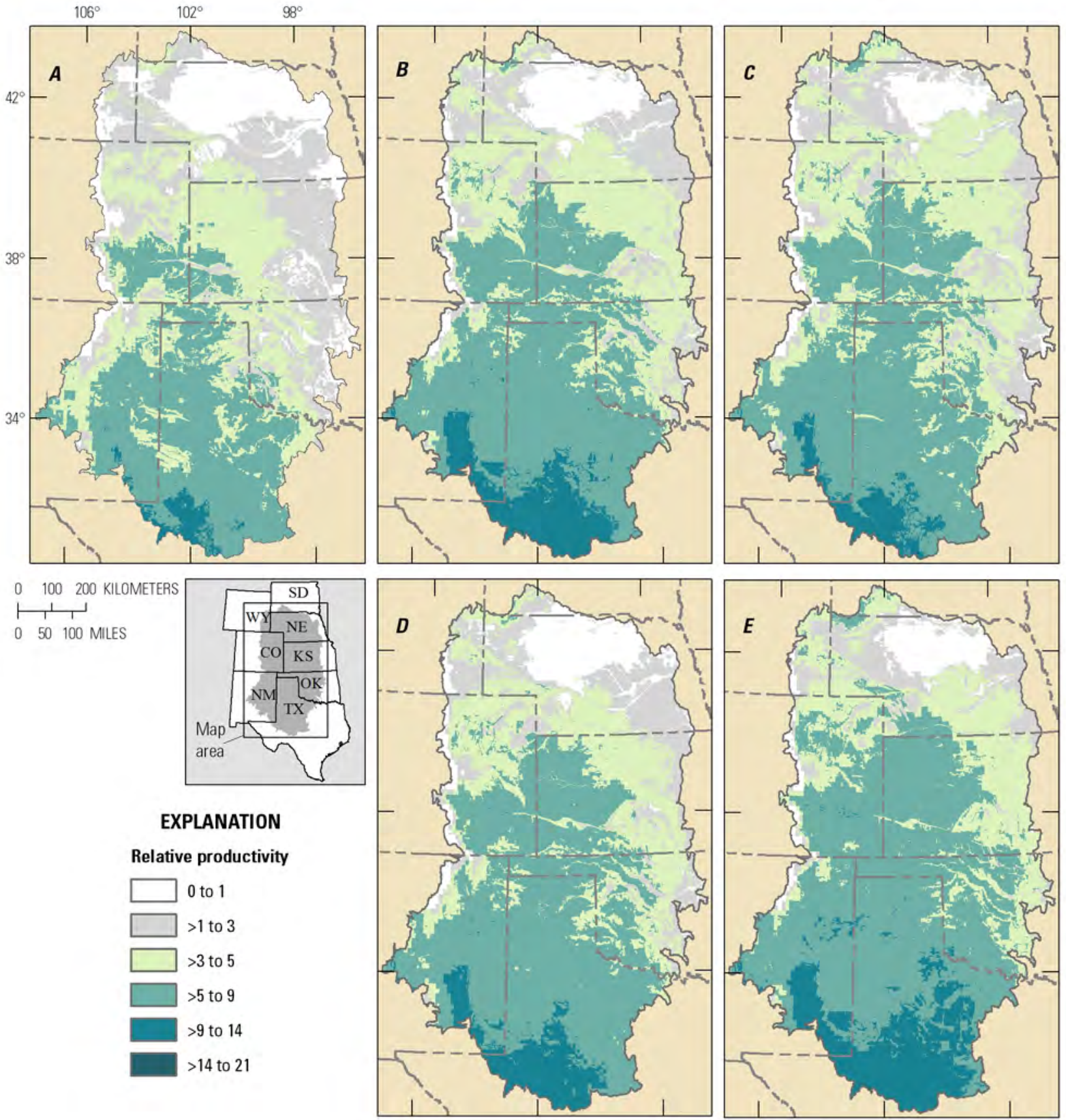

Base map from U.S. Geological Survey, National Map,1:18,883,014

North American Albers Equal Area Conic projection

North American Datum of 1983 , Central Meridian - $102^{\circ}$ W., Standard Parallels $20^{\circ} \mathrm{N}$. and $60^{\circ} \mathrm{W}$.

Figure A1.4. Contemporary and predicted relative productivity of Bouteloua dactyloides (buffalograss) using four climate scenarios in the Southern Great Plains of the United States. A, Relative productivity (RP) estimated for contemporary (1981-2010) climatic conditions and predicted relative productivity (scenario forecasts) for: $B$, warm-wet; $C$, hot-wet; $D$, warm-dry; $E$, hot-dry. $R P=0.72$ (Temp)-0.12 (Precip) -0.04 (Sand) +3.08 , (table 3 ), where Temp is mean annual temperature in degrees Celsius, and Precip is mean annual precipitation in centimeters, calculated from 30-year records (contemporary) or simulated conditions (general circulation models [GCM] results); sand, percent sand in the surface soil attributes. 

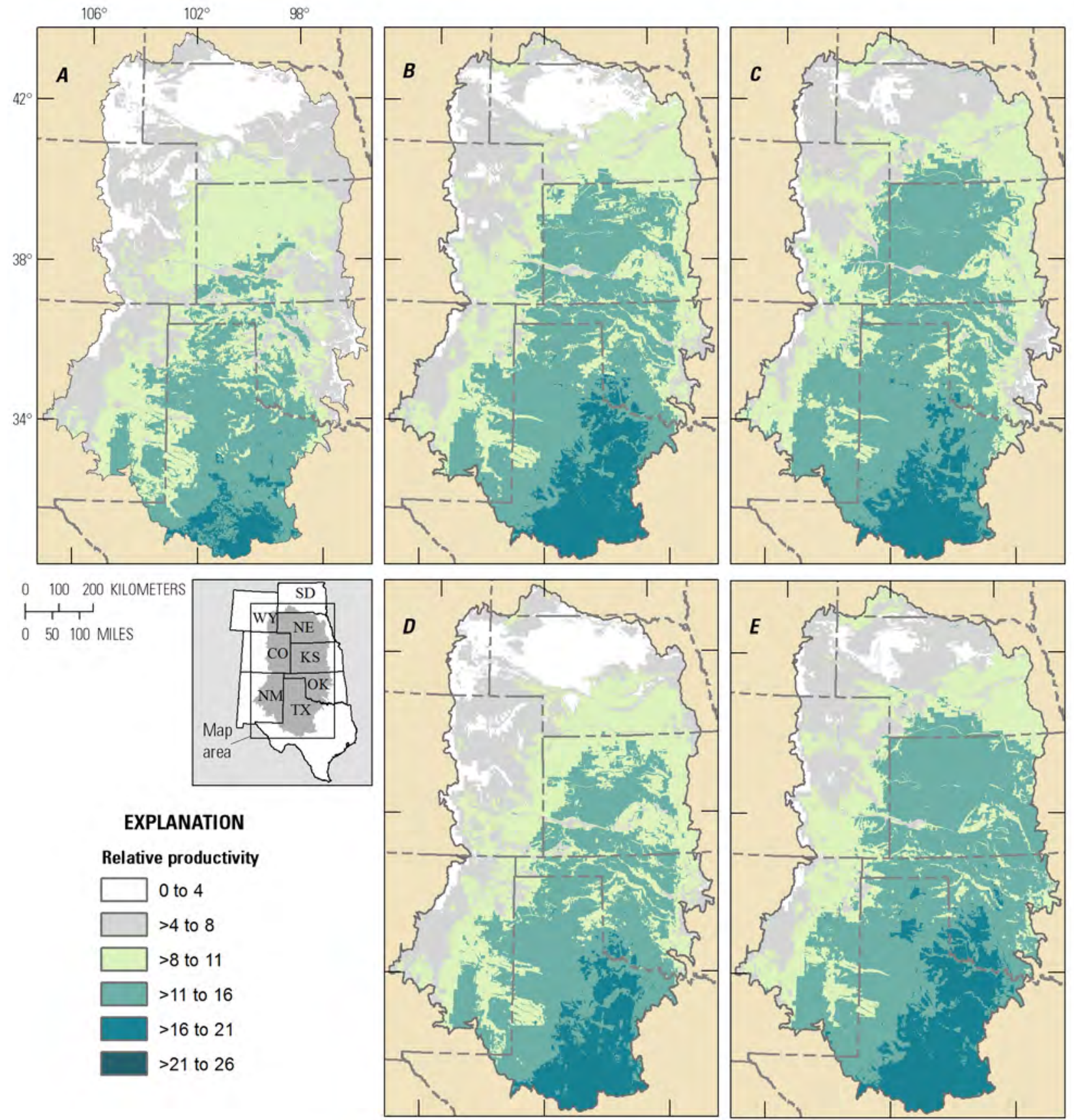

\section{EXPLANATION}

Relative productivity

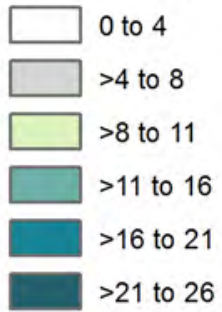

Base map from U.S. Geological Survey, National Map,1:18,883,014

North American Albers Equal Area Conic projection

North American Datum of 1983 , Central Meridian $-102^{\circ}$ W., Standard Parallels $20^{\circ} \mathrm{N}$. and $60^{\circ} \mathrm{W}$.

Figure A1.5. Contemporary and predicted relative productivity of Bouteloua curtipendula (sideoats grama) using four climate scenarios in the Southern Great Plains of the United States. A, Relative productivity (RP) estimated for contemporary (1981-2010) climatic conditions and predicted relative productivity (scenario forecasts) for: $B$, warm-wet; $C$, hot-wet; $D$, warm-dry; $E$, hot-dry. $\mathrm{RP}=1.13$ (Temp)+0.41(Precip)-0.004(Precip) ${ }^{2}-0.07$ (Sand)-12.3, (table 3), where Temp is mean annual temperature in degrees Celsius, and Precip is mean annual precipitation in centimeters, calculated from 30-year records (contemporary) or simulated conditions (general circulation Model [GCM] results); sand, percent sand in the surface soil attributes. 

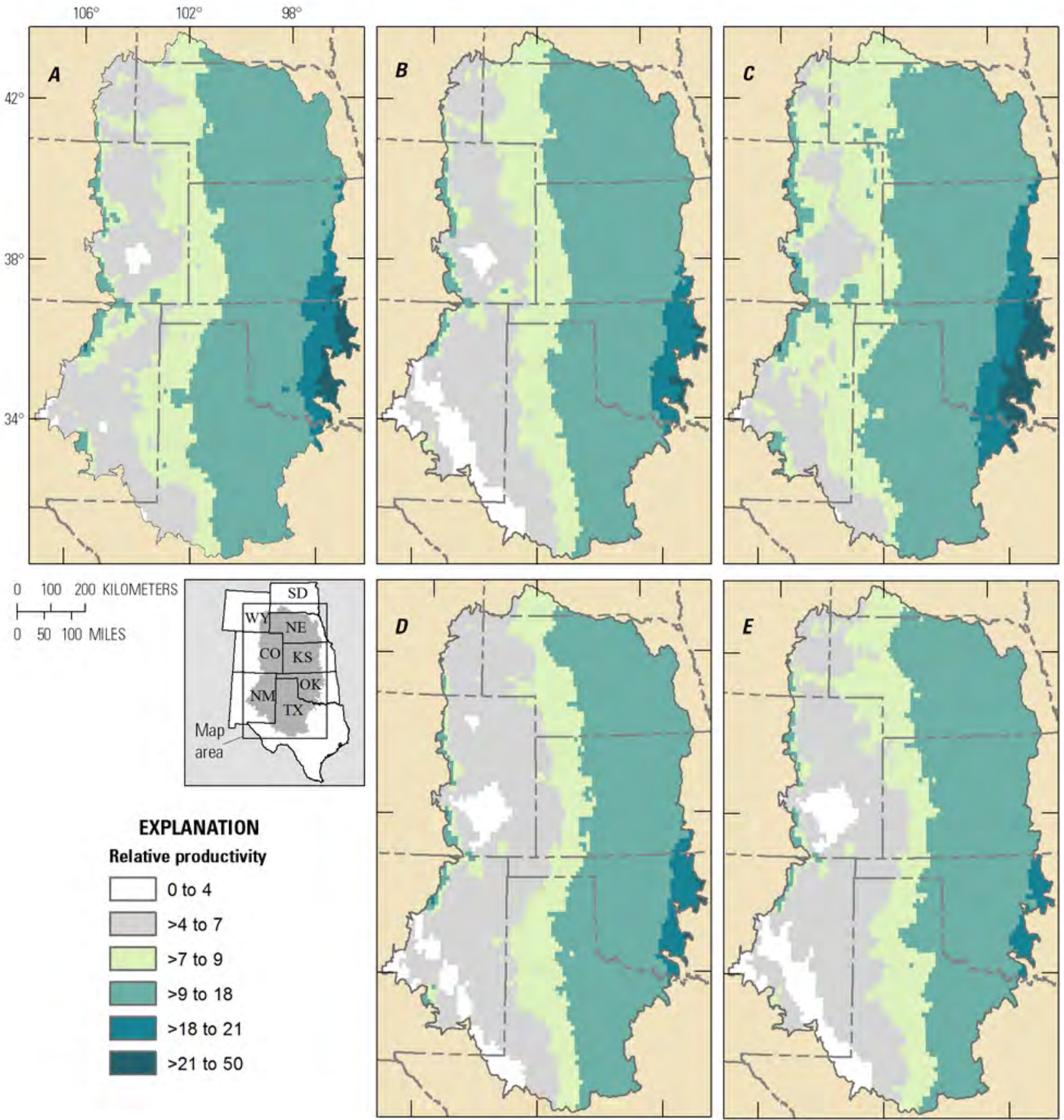

Base map from U.S. Geological Survey, National Map, 1:18,883,014

North American Albers Equal Area Conic projection

North American Datum of 1983 , Central Meridian - $102^{\circ}$ W., Standard Parallels $20^{\circ} \mathrm{N}$. and $60^{\circ} \mathrm{W}$.

Figure A1.6. Contemporary and predicted relative productivity of Schizachyrium scoparium (little bluestem) using four climate scenarios in the Southern Great Plains of the United States. $A$, Relative productivity (RP) estimated for contemporary (1981-2010) climatic conditions and predicted relative productivity (scenario forecasts) for: $B$, warm-wet; $C$, hot-wet; $D$, warm-dry; $E$, hot-dry. $\mathrm{RP}=0.26$ (Precip)-4.04, (table 3), where Precip is mean annual precipitation in centimeters, calculated from 30-year records (contemporary) or simulated conditions (general circulation Model [GCM] results). 

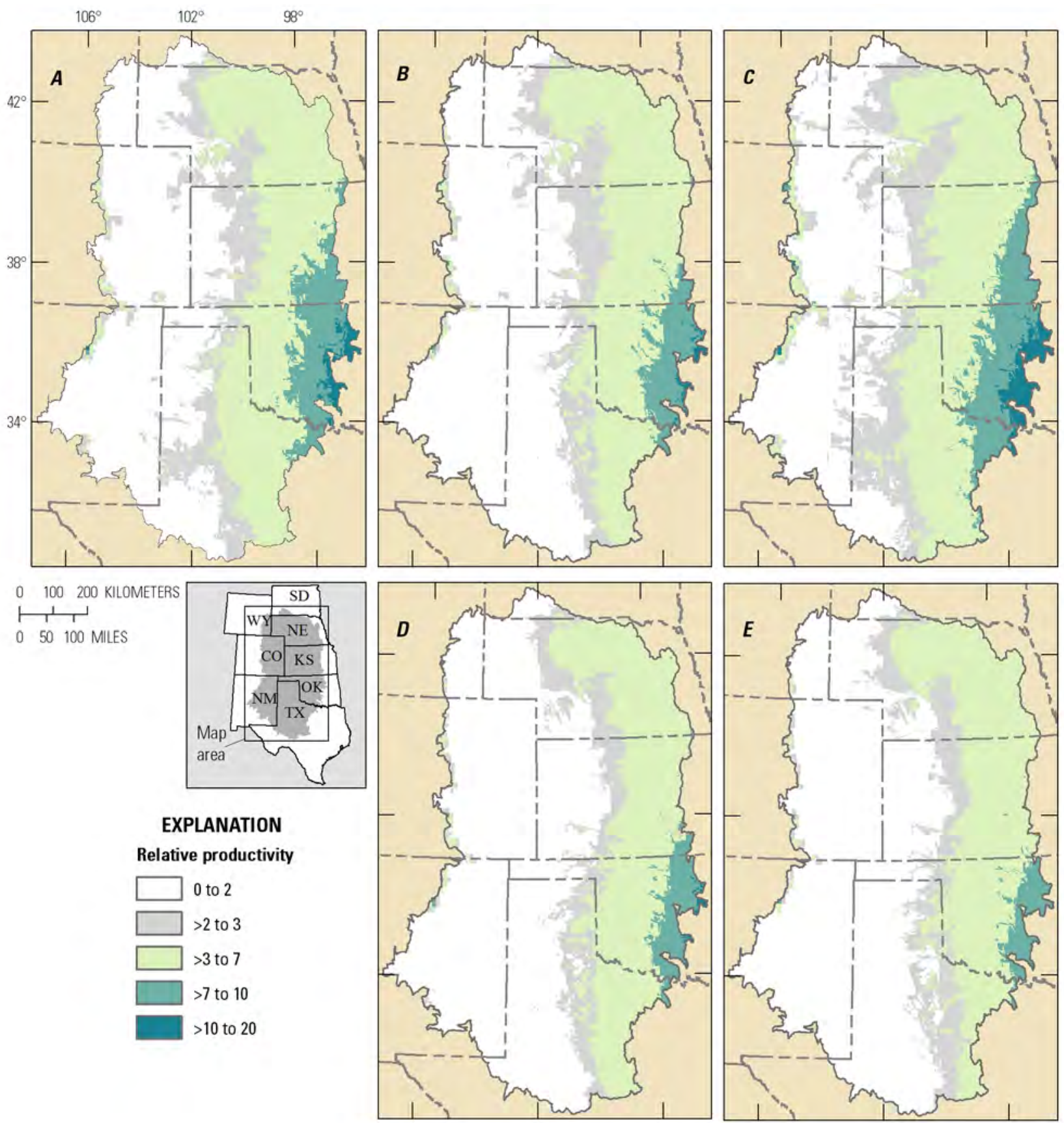

\section{EXPLANATION}

Relative productivity

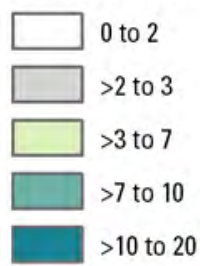

Base map from U.S. Geological Survey, National Map,1:18,883,014

North American Albers Equal Area Conic projection

North American Datum of 1983 , Central Meridian $-102^{\circ}$ W., Standard Parallels $20^{\circ} \mathrm{N}$. and $60^{\circ} \mathrm{W}$.

Figure A1.7. Contemporary and predicted relative productivity of Sorghastrum nutans (Indiangrass) using four climate scenarios in the Southern Great Plains of the United States. A, Relative productivity (RP) estimated for contemporary (1981-2010) climatic conditions and predicted relative productivity (scenario forecasts) for: $B$, warm-wet; $C$, hot-wet; $D$, warm-dry; $E$, hot-dry. $\mathrm{RP}=0.17(\operatorname{Precip})+0.02(\mathrm{Sand})-7.4$, (table 3), where Precip is mean annual precipitation in centimeters, calculated from 30-year records (contemporary) or simulated conditions (general circulation Model [GCM] results); and, sand is percent sand in the surface soil attributes. 

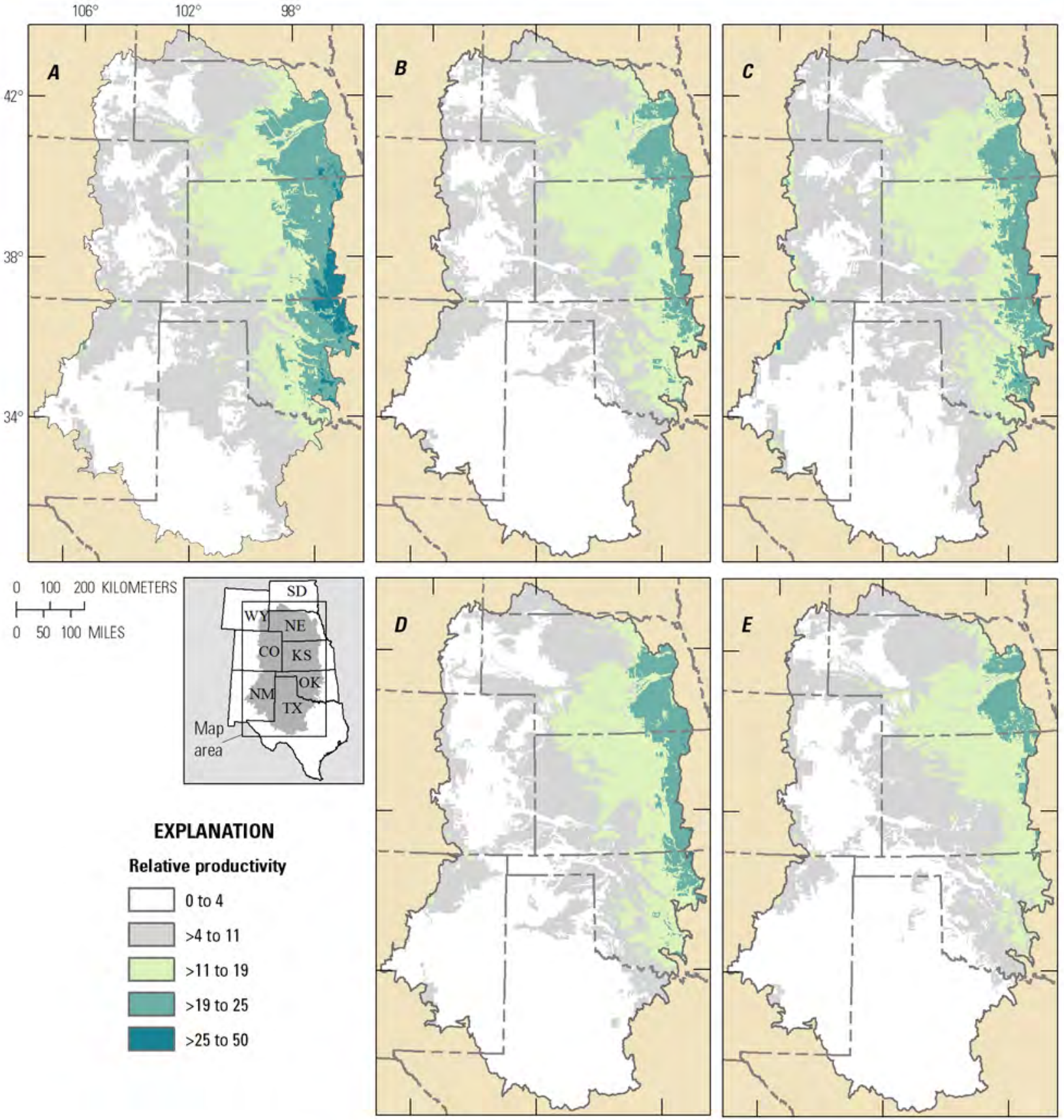

\section{EXPLANATION}

Relative productivity

$\square 0$ to 4
$\square>4$ to 11
$\square>11$ to 19
$>>19$ to 25
$>25$ to 50

Base map from U.S. Geological Survey, National Map,1:18,883,014

North American Albers Equal Area Conic projection

North American Datum of 1983 , Central Meridian $-102^{\circ}$ W., Standard Parallels $20^{\circ} \mathrm{N}$. and $60^{\circ} \mathrm{W}$.

Figure A1.8. Contemporary and predicted relative productivity of Andropogon gerardii (big bluestem) using four climate scenarios in the Southern Great Plains of the United States. A, Relative productivity (RP) estimated for contemporary (1981-2010) climatic conditions and predicted relative productivity (scenario forecasts) for: $B$, warm-wet; $C$, hot-wet; $D$, warm-dry; $E$, hot-dry. $\mathrm{RP}=3.08$ (Temp)+0.41(Precip)-0.16(Temp) ${ }^{2}+0.14$ (Silt)-31.9, (table 3), where Temp is mean annual temperature in degrees Celsius, and Precip is mean annual precipitation in centimeters, calculated from 30-year records (contemporary) or simulated conditions (general circulation Model [GCM] results); silt, percent silt in the surface soil attributes. 


\section{Model Convergence and Uncertainty}

The range in model results, indicating agreement or disparity among predicted conditions for each indicator species, reflects areas where the predicted productivity was similar for all climate scenarios evaluated or where model convergence was high (figs. 1-9). High model convergence reflects productivity predictions that have low sensitivity to the choice of climate scenarios. Low model convergence reflects higher uncertainty and sensitivity to the climate scenarios evaluated.
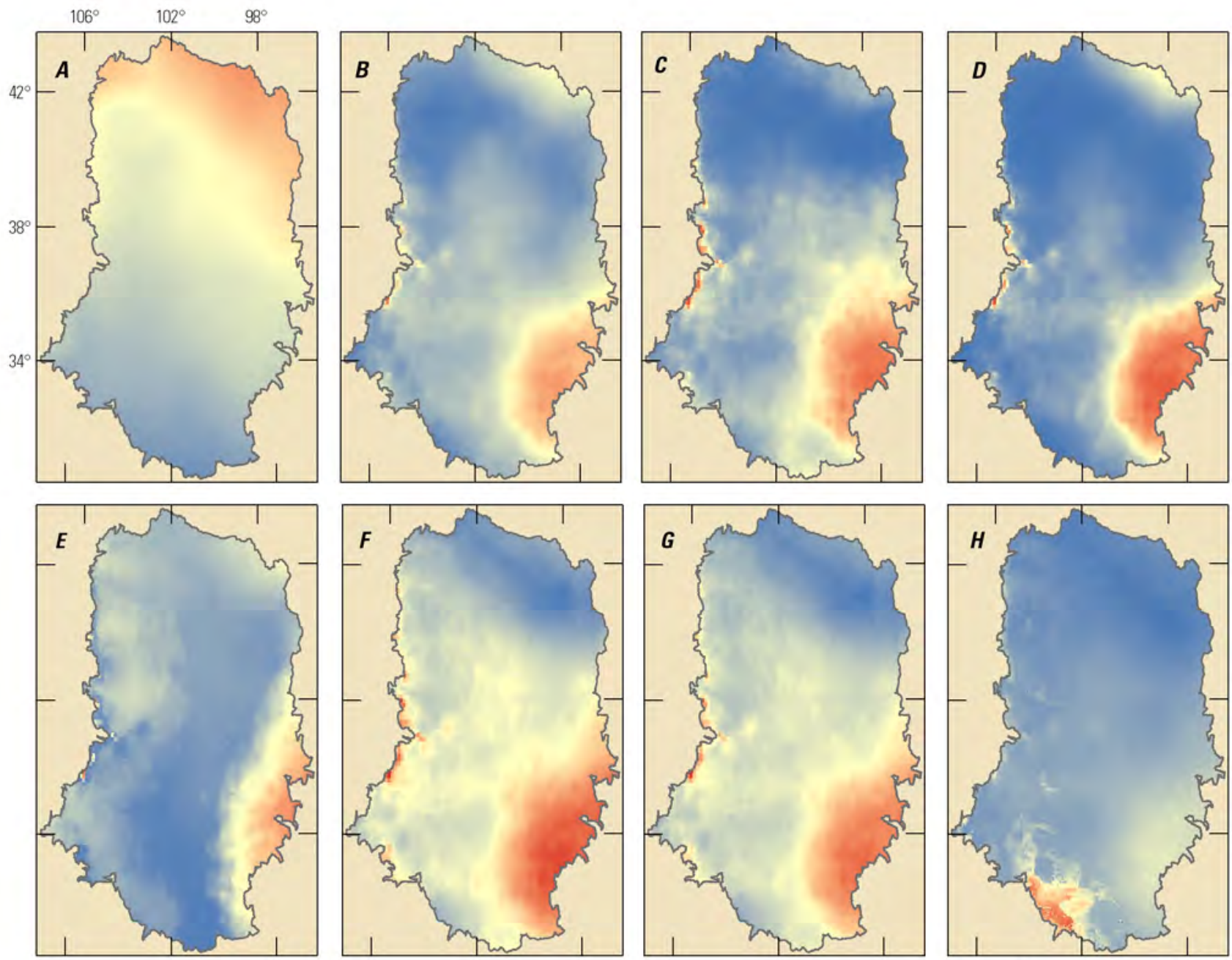

Base map from U.S. Geological Survey National Map, $1: 75,486,840$

0100200 KILOMETERS $\vdash+{ }_{1}^{1}$

North American Albers Equal Area Conic projection

050100 MILES

EXPLANATION

North American Datum of 1983

Model agreement

Central Meridian $-102^{\circ}$ W.

Standard Parallels $20^{\circ} \mathrm{N}$. and $60^{\circ} \mathrm{W}$.
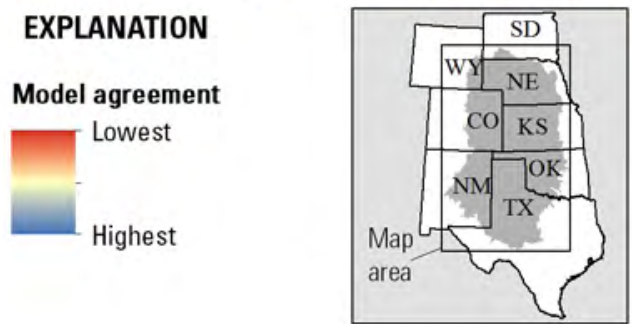

Figure A1.9. Agreement and disparity among relative production models using the four climate scenarios in the Southern Great Plains of the United States. A, Pleuraphis mutica (tobosagrass); B, Bouteloua eriopoda (black grama); $C$, Bouteloua gracilis (blue grama); $D$, Bouteloua dactyloides (buffalograss); E, Bouteloua curtipendula (sideoats grama); F, Schizachyrium scoparium (little bluestem); G, Sorghastrum nutans (Indiangrass); H, Andropogon gerardii (big bluestem). Shades of blue indicate agreement (small differences), yellow indicates moderate similarity, and shades of red indicate larger differences (disparity) among the climate-scenario model results. The estimated relative productivity for each species is provided in the previous figures (appendix figures A1.1 to A1.8). 
For more information concerning the research in this report, contact the Center Director, USGS Fort Collins Science Center

2150 Centre Ave., Bldg. C

Fort Collins, CO 80526-8118

(970) 226-9398

Or visit the Fort Collins Science Center website at https://www.usgs.gov/centers/fort

Publishing support provided by the Denver Publishing Service Center 


\section{$\frac{2}{2}$}

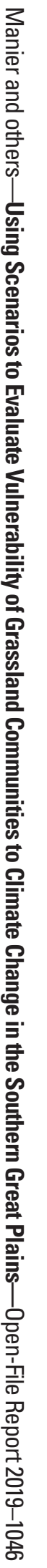

